
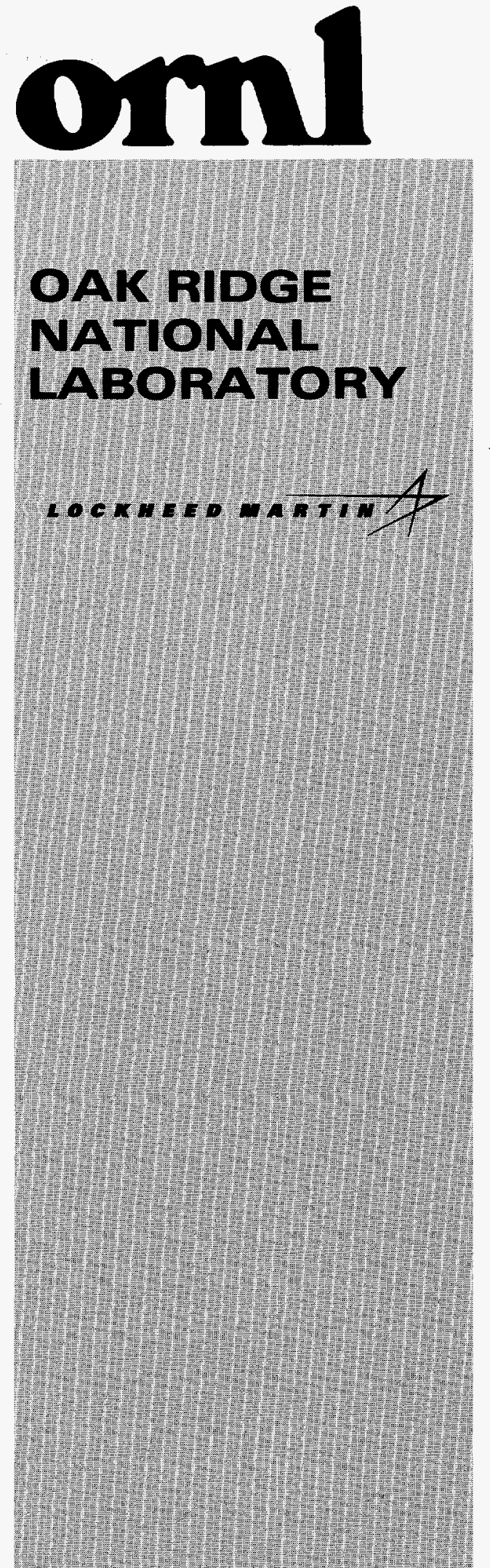

WHMGEo Mo opendteo bi

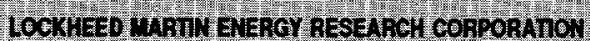
FOA THEUTEOSTIES

DEPARIVIT CF ENEHCY

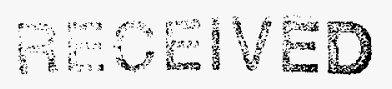

ORNLTM-13188

\title{
Recommended ALIs and DACs for 10 CFR Part 20: A Consistent Numerical Set
}

\author{
K. F. Eckerman
}

DISTRBAITON OF THIS DOCUMENT IS UMRMTTED ph

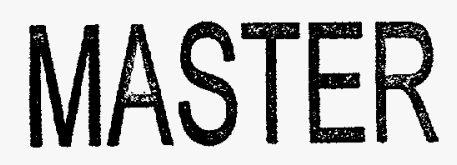


This report has been reproduced directly from the best available copy.

Available to DOE and DOE contractors from the Office of Scientific and Technical Information, P. O. Box 62, Oak Ridge, TN 37831; prices available from (423) 576-8401, FTS 626-8401.

Available to the public from the National Technical Information Service, U.S. Department of Commerce, 5285 Port Royal Road, Springfield, VA 22161.

This report was prepared as an account of work sponsored by an agency of the United States Government. Neither the United States Government nor any agency thereof, nor any of their employees, makes any warranty, express or implied, or assumes any legal liability or responsibility for the accuracy, completeness, or usefulness of any information, apparatus, product, or process disclosed, or represents that its use would not infringe privately owned rights. Reference herein to any specific commercial product, process, or service by trade name, trademark, manufacturer, or otherwise, does not necessarily constitute or imply its endorsement, recommendation, or favoring by the United States Government or any agency thereof. The views and opinions of authors expressed herein do not necessarily state or reflect those of the United States Government of any agency thereof. 
ORNL/TM-13188

RECOMMENDED ALIs and DACs FOR 10 CFR PART 20:

A Consistent Numerical Set

\author{
K. F. Eckerman \\ Health Sciences Research Division \\ Oak Ridge National Laboratory
}
Manuscript Completed
May 1, 1996

\author{
Prepared for the \\ U.S. Nuclear Regulatory Commission \\ Office of Nuclear Regulatory Research \\ Washington, DC 20555 \\ under Interagency Agreement DOE 1886-8137-62 \\ Prepared by the \\ Oak Ridge National Laboratory \\ Oak Ridge, Tennessee 37831-6285 \\ managed by \\ LOCKHEED MARTIN ENERGY RESEARCH CORP. \\ for the \\ U.S. DEPARTMENT OF ENERGY \\ under contract DE-AC05-96OR22464.
}




\section{DISCLAIMER}

Portions of this document may be illegible in electronic image products. Images are produced from the best available original document. 
CONTENTS

ACKNOWLEDGEMENT $\ldots \ldots \ldots \ldots \ldots \ldots \ldots \ldots \ldots \ldots \ldots$ v

ABSTRACT $\ldots \ldots \ldots \ldots \ldots \ldots \ldots \ldots \ldots \ldots \ldots \ldots \ldots \ldots \ldots \ldots \ldots \ldots \ldots$ vii

1. INTRODUCTION $\ldots \ldots \ldots \ldots \ldots \ldots \ldots \ldots \ldots \ldots \ldots \ldots \ldots$

2. RADIATION PROTECTION GUIDANCE $\ldots \ldots \ldots \ldots \ldots \ldots \ldots \ldots$

3. CALCULATION OF SECONDARY LIMITS $\ldots \ldots \ldots \ldots \ldots \ldots \ldots 7$

4. REGULATORY ISSUES $\ldots \ldots \ldots \ldots \ldots \ldots \ldots \ldots \ldots \ldots \ldots$

5. RADON DECAY PRODUCTS $\ldots \ldots \ldots \ldots \ldots \ldots \ldots \ldots \ldots \ldots \ldots$

6. RECOMMENDED VALUES FOR RADIONUCLIDE ALIs AND DACs 18

7. DISCUSSION AND CONCLUSIONS $\ldots \ldots \ldots \ldots \ldots \ldots \ldots \ldots 20$

REFERENCES $\ldots \ldots \ldots \ldots \ldots \ldots \ldots \ldots \ldots \ldots \ldots \ldots \ldots \ldots \ldots \ldots \ldots \ldots \ldots$

APPENDIX A: Recommended Values for the Quantities of Appendix B

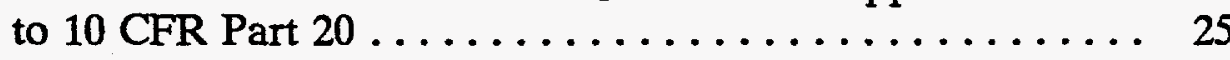





\section{ACKNOWLEDGEMENT}

This work at Oak Ridge National Laboratory was supported by the Nuclear Regulatory Commission. The earlier activities at ORNL in support of the International Commission on Radiological Protection were sponsored primarily by the Department of Energy. The support of both of these organizations has been critical to the development of our dosimetry research program and is gratefully acknowledged.

The author further wishes to acknowledge the patient support of Shlomo S. Yaniv of the Nuclear Regulatory Commission and the assistance of Barbara Clark, Oak Ridge National Laboratory, in the preparation of the final manuscript for publication. 



\begin{abstract}
Appendix B to 10 CFR Part 20 contains numerical data for controlling the intake of radionuclides in the workplace or in the environment. These data, derived from the recommendations of the International Commission on Radiological Protection (ICRP), do not provide a numerically consistent basis for demonstrating compliance with the limitation on dose stated in the regulation. This situation is largely a consequence of the numerical procedures used by the ICRP which did not maintain, in a strict numerical sense, the hierarchial relationship among the radiation protection quantities. In this work recommended values of the quantities in Appendix B to CFR Part 20 are developed using the dose coefficients of the applicable ICRP publications and a numerical procedure which ensures that the tabulated quantities are numerically consistent.
\end{abstract}





\section{INTRODUCTION}

Radiation protection standards for workers and the general public are based, in the United States, on a hierarchy of recommendations including those of the International Commission on Radiological Protection (ICRP), the National Council on Radiation Protection and Measurements (NCRP) and the responsible Federal agencies. The current standards in the United States were signed into law by President Ronald Reagan in 1987 (EPA 1987). The Nuclear Regulatory Commission (NRC) revised its radiation protection standards for protection against ionizing radiation in an amendment to 10 CFR Part 20 (NRC 1992a). That amendment serves as the basis for NRC's regulation of ionizing radiation. The numerical data for controlling exposure to and intake of specific radionuclides in the workplace and in the environment are contained in Appendix B of 10 CFR Part 20.

The data of Appendix B of 10 CFR Part 20 were derived from Publication 30, Parts 1-4 (ICRP 1979, 1980, 1981a, 1988) of the ICRP. Further guidance regarding acceptable use of these data in demonstrating compliance with the occupational limits was provided in Regulatory Guide 8.34 (NRC 1992b). The utility of that guidance is impacted by the failure of the data of Appendix B to fully preserve the hierarchical relationships among the various radiation protection quantities. The purpose of this report is to recommend a set of data for controlling radionuclides in the workplace and the environment that adheres to the principles and dose limits of 10 CFR Part 20 and preserves the hierarchical relationships among the various radiation protection quantities.

A cursory examination of Appendix B of 10 CFR Part 20 reveals a number of deficiencies. For example, the presentation implies a relationship between the clearance classes assigned to chemical forms of the radionuclide that may be inhaled and the limit on intake by ingestion. Even for radionuclides where chemical form is well known to influence the magnitude of the radiation dose, the limits on the activity that might be ingested are specified without reference to chemical form. In tabulating the data from the recommendation documents, the NRC apparently chose to ignore these known differences in radiation dose based on chemical form and hence tabulated only the most restrictive value for ingestion of each radionuclide. This decision can have a substantial impact since, for example, the uptake to blood of various chemical forms of plutonium considered in Part 4 of Publication 30 (ICRP 1988) varied more than two orders of magnitude.

Many examples of numerical values of questionable origin can be seen in Appendix B. For example, the entries for ingestion of $\mathrm{Be}-10$ and F-18 indicate that the intakes of these radionuclides are limited by the constraint on organ dose (non-stochastic health effects), yet identical values are tabulated for the constraint on the effective dose (associated with stochastic health effects). The data for inhalation of Os-189m provides another interesting example. The annual limits on intake of Os-189m in chemical forms corresponding to all three clearance classes were assigned the same value, yet when those values were divided by the volume of air breathed in a year - a constant, three different answers were obtained. Additional numerical artifacts are evident in the tabulations. The artifacts arise, in part, as a consequence of an excessive rounding procedure used by the ICRP in Publication 30 - excessive in that it fails to preserve the numerical relationship between the various quantities. Unfortunately these artifacts are amplified when, as set forth in Regulatory Guide 8.34, compliance with the dose limits of 10 CFR Part 20 is demonstrated using various protection quantities. That is, a situation demonstrated to be in compliance based on one protection quantity may be found to be in non-compliance by a mathematically equivalent analysis using a different 
protection quantity. Furthermore, one does not know a priori which analysis would be conservative. These matters were first called to the author's attention by M. W. Lantz in 1991 and have been discussed in the open literature (Poston and Poston 1992, Windham et al. 1994) although no solution nor basis for a recommendation was presented.

In this report, a computational procedure is established to derive numerical values of the radiation protection quantities which are consistent with their hierarchical relationships. The procedure is used to tabulate the numerical data in the manner of Appendix B to 10 CFR Part 20. We begin with a brief discussion of the radiation protection guidance set forth in 10 CFR Part 20 to define the relationship between the primary and secondary limits and to identify the origins of the numerical difficulties noted above. We then illustrate the impact of these numerical data in demonstrating regulatory compliance and define a computational procedure which yields numerical values for the radiation protection quantities that are consistent with their hierarchical relationship. Finally, a full set of internally consistent numerical data is presented in an appendix in the manner of Appendix B to 10 CFR Part 20. 


\section{RADIATION PROTECTION GUIDANCE}

Radiological control of the workplace can be demonstrated by comparison of the estimated radiation dose with the primary dose limits (numerical constraints on dose). In the case of intakes of radionuclides into the body either through ingestion, inhalation, or wounds, the dose must be calculated from knowledge of the intake or the time-integrated activity concentration of the radionuclides in air or water. Committee 2 of the ICRP, in Publication 30 (ICRP 1979), translated the primary dose limits stated in Publication 26 (ICRP 1977) into secondary limits representing the quantity of the radionuclide which if inhaled or ingested by a reference individual would irradiate the body to levels corresponding to the primary limits. The secondary limits were computed assuming the anatomical and physiological characterization of Reference Man (ICRP 1975) and the dosimetric and biokinetic models of Publication 30 (ICRP 1979).

\section{Primary Limits}

Paragraph 10 CFR 20.1201 of the revised 10 CFR Part 20, states the primary limits (dose limits) for occupationally exposed adults. The limits apply to the sum of the dose received from external exposure and the dose from internally deposited radionuclides. Paragraph 20.1201(a) states the limits as:

a. the annual effective dose equivalent is limited to $5 \mathrm{rem}(0.05 \mathrm{~Sv})$,

b. the annual dose equivalent to any organ or tissue (other than lens of the eye) is limited to 50 rem $(0.5 S v)$.

The occupational dose limits for minors, stated in paragraph 20.1207, are $10 \%$ of the dose limits for adult workers - paragraph 210.1208 establishes a dose limit for the embryo/fetus of $0.5 \mathrm{rem}(5 \mathrm{mSv})$. In the discussions below, the limits on the effective dose equivalent and dose equivalent in organ or tissue $T$ are represented by the symbols $H_{\text {Limin, }, E}$ and $H_{L \text { imit, }, T}$, respectively, to enable presenting equations without reference to a particular system of units.

The effective dose equivalent, $H_{E}$, is defined as

$$
H_{E}=\sum_{T} w_{T} H_{T}
$$

where $w_{T}$ is the weighting factor for organ or tissue $T$, and $H_{T}$ is the corresponding dose equivalent for organ or tissue $T$. The summation in Eq. 1 extends over all irradiated tissues. The weighting factor for an organ or tissue represents the contribution of that tissue to the risk of cancer (genetic effects if the organ is the gonads) when the body is irradiated in a uniform manner. The weighting factors are given in Table 1 . 
Table 1. Tissue Weighting Factors

\begin{tabular}{ll}
\hline Organ/Tissue & $w_{T}$ \\
\hline Gonads & 0.25 \\
Breast & 0.12 \\
Lung & 0.12 \\
Red Marrow & 0.12 \\
Bone Surface & 0.03 \\
Thyroid & 0.03 \\
Remainder $^{*}$ & 0.30 \\
\hline
\end{tabular}

* A value of 0.06 is to be applied to the five most highly irradiated tissues not explicitly named, excluding skin.

For the various radionuclides, ICRP Committee 2 translated the annual dose limits into annual limits on intake and/or air concentrations which, if experienced by Reference Man (ICRP 1975), would result in radiation doses corresponding to the annual dose limits. The starting point in the translation is the computation of the committed dose equivalent in the various organs and tissues of the body per unit intake. The committed dose equivalent is the total dose equivalent that organs or tissues will experience in the 50-year period following the intake of a radionuclide and is denoted by $\boldsymbol{H}_{50, T}$; the dose coefficient (the committed dose equivalent per unit intake) is denoted as $h_{50, T^{-}}$In a similar manner, we denote the committed effective dose equivalent as $H_{S 0, E}$ and the corresponding dose coefficient as $h_{50, E}$. Committee 2 published dose coefficients for those tissues of the body that contributed substantially in determination of the annual limit on intake but they did not publish the effective dose equivalent coefficients (ICRP 1979). The coefficients were published in Federal Guidance Report No. 11 (Eckerman $e t a l .1988$ ) and a full set of dose coefficients is available from Eckerman and Ryman (1993). 


\section{Secondary Limits}

The annual intake $I$ of a radionuclide, by ingestion or inhalation, must satisfy the constraint on the effective dose equivalent, $H_{\text {Limit, }}$, and the constraint on organ dose, $H_{\text {Limit. } T}$. That is, the product of the activity inhaled or ingested (the intake) and the dose coefficient must be less than the applicable dose limit; i.e.,

$$
\begin{gathered}
I h_{50, E} \leq H_{\text {Limix, },} \text { and } \\
I h_{50, T} \leq H_{\text {Limit,T }} \text { for all } T .
\end{gathered}
$$

The constraint of Eq. $3 a$ is frequently referred to as the stochastic constraint since the effective dose equivalent is a measure of the risk of cancer and genetic effects suitable for radiation protection purposes, i.e., a linear function of dose without threshold. The annual intake permitted by this constraint, $A L I_{s}$, is

$$
A L I_{S}=\frac{H_{\text {Limin, } E}}{h_{50, E}}
$$

The constraint of Eq. 3b, the "non-stochastic" or "deterministic" constraint, was formulated to avoid impairing the functioning of organs and tissues of the body. The annual intake permitted by this constraint, $A L I_{N S}$, is

$$
A L I_{N S}=\operatorname{MIN}\left(\frac{H_{\text {Limix,T }}}{h_{50, T}} ; T=1,2, \ldots, M\right)
$$

where the function $M I N$ denotes the minimum value of the $M$ arguments. The annual limit on intake, $A L I$, must satisfy both constraints and thus is

$$
A L I=M N\left(A L I_{S}, A L I_{N S}\right) \text {. }
$$

The $A L I$ is the minimum activity of the radionuclide that can be taken into the body and satisfy the constraint on the effective dose equivalent, $A L I_{S}$, and the constraint on the dose equivalent in the individual organs and tissues of the body, $A L I_{N S}$.

In Appendix B of 10 CFR Part 20, if the $A L I$ for a radionuclide was based on the non-stochastic constraint, the intake corresponding to the stochastic constraint, $A L I_{S}$, was also tabulated along with the identity of the organ or tissue involving the non-stochastic constraint. It has become common practice to speak of the "nonstochastic ALI (NALI)" and the "stochastic ALI (SALI)" although only a single $A C I$ satisfies the dose limits.

The concentration of a radionuclide in air, which if breathed by Reference Man during a working year, that results in the intake of an $A L I$ is referred to as the Derived Air Concentration (DAC). The $D A C$ is given by 


$$
D A C=\frac{A L I}{q}
$$

where $q$ is the annual intake of the radionuclide per unit airborne concentration. For all radionuclides, other than tritiated water vapor and radon - which are discussed later, $q$ is simply the annual occupational intake of air, $2.410^{3} \mathrm{~m}^{3}$ (the product of $2000 \mathrm{~h} \times 0.02 \mathrm{~m}^{3} / \mathrm{min} \times 60 \mathrm{~min} / \mathrm{h}$ ). In the case of tritiated water vapor, the intake occurs through two routes: inhalation and dermal (skin) absorption. The total intake of tritiated water through these two routes is 1.5 times that due only to inhalation; i.e., $q$ is $3.610^{3} \mathrm{~m}^{3}$ for tritiated water vapor.

Some airborne radionuclides, in particular isotopes of the noble gas elements, do not deposit within the lung when inhaled and they are not metabolized by the body to any appreciable extent. The secondary limits for these radionuclides are based, therefore, on consideration of the external dose due to submersion in air containing the radionuclide. For such situations, the $D A C$ may be derived directly from the primary limits. The annual average airborne concentration $\bar{C}$ of the radionuclide must satisfy the constraints:

$$
\begin{gathered}
2000 \dot{h}_{E, \text { Sub }} \bar{C} \leq H_{\text {Limit, } E} \\
2000 \dot{h}_{\text {Lens, sub }} \bar{C} \leq H_{\text {Limit, Lens }} \\
2000 \dot{h}_{T, \text { sub }} \bar{C} \leq H_{\text {Limit,T }} \text { for all } T,
\end{gathered}
$$

where $\dot{h}_{E, \text { sub }}, \dot{h}_{\text {Lens, sub }}$, and $\dot{h}_{T, \text { sub }}$ are dose rate coefficients for the effective dose equivalent, the lens of the eye, and tissue $T$, respectively, due to submersion exposure per unit activity concentration of the radionuclide in air. The factor 2000 denotes the number of working hours in a year. The dose rate coefficients are thus assumed to have time units of inverse hours. The DAC is the maximum value of $\bar{C}$ that satisfies the above inequalities. 


\section{CALCULATION OF SECONDARY LIMITS}

Establishing a limit on intake of a radionuclide begins with a calculation of the committed dose equivalent in the various organs and tissues of the body per unit intake of the radionuclide. Such factors depend on the chemical form of the radionuclide and are referred to as dose factors or dose coefficients. For exposures to airborne noble gas radionuclides, referred to as submersion, the activity concentration corresponding to the dose limits, the derived air concentrations $(D A C)$, are calculated from dose coefficients relating the organ dose rate to the airborne concentration. In the Supplements to Publication 30, the ICRP published the coefficients for those organs and tissues necessary to reproduce the calculations of the $A L I$ and $D A C$. At the time Publication 30 was prepared, the ICRP had not used the term "effective dose equivalent" but referred to the "sum of the weighted dose equivalent." ICRP Committee 2 devised a procedure, the so-called $10 \%$ rule, to restrict the published coefficients to only those tissues which were numerically significant in establishing the $A L I$. In addition, the ICRP continued its earlier practice of rounding the secondary limits to a single digit. As shown below, the $10 \%$ rule and the rounding procedure disrupts the numerical relationships among the quantities.

\section{ICRP Publication 30's 10\% Rule}

ICRP Committee 2 formulated and used the $10 \%$ rule to limit the numerical data presented in the Supplements to Publication 30. Those organs or tissues $T$ for which the product of the applicable tissue weighting factor and committed dose equivalent per unit intake, $w_{T} h_{50, T}$, was less than $10 \%$ of the maximum value of $w_{T} h_{50, r}$ were not considered in the computation of the $A L I s$ and $D A C s$ and thus data for these tissues do not appear in the Supplements. This procedure was very effective in reducing the size of the Supplements; e.g., only data for the thyroid gland are found in the Supplements for radioiodines. In computations of dose, however, the $10 \%$ rule should not be used and was not used in the computations of the effective dose equivalent coefficients given in Federal Guidance Report No.11 (Eckerman et al. 1988). Furthermore, ICRP Committee 2 has not used the $10 \%$ rule in any publications following Publication 30. An illustrative example is presented below for which the contributions to the effective dose equivalent by tissue retained with the $10 \%$ rule accounts for slightly more than half of the effective dose equivalent.

\section{Rounding Procedures}

Committee 2 rounded the calculated $A L I$ and $D A C$ values to a single digit for publication. The rounding procedure employed was consistent with usual numerical rounding; i.e., values between 0.5 and 1.4 round to 1 , values between 1.5 and 2.4 round to 2 , and so on. Under this procedure some values are rounded upward and other values downward. Since some $A L I$ values were rounded upward, the rounding procedure fails to ensure that an intake of one $A L I$ will not result in a dose numerically in excess of the dose limit. 


\section{Other Considerations}

In Publication 30, Committee 2's decision as to whether the annual limit on intake was limited by nonstochastic or stochastic constraints was based on a comparison of the numerical values of $A L I_{S}$ and $A L I_{N S}$ as represented within the computer, not the rounded values that were published. This procedure resulted in the situation noted in the introduction in which the $A L I s$ for ingestion of Be-10 and F-18 were listed as being based on the nonstochastic constraint and yet the exact same numerical value of intake was tabulated for the stochastic constraint.

In addition, ICRP Committee 2 computed the DACs from the computer's representation of the $A L I s$, not from the rounded or published values of the $A L I s$. The DACs were then rounded to a single digit. This explains the situation noted in the introduction for Os-189m. Again, the rounding procedure makes it possible for an annual occupational exposure $(2000 \mathrm{~h})$ to an airborne activity concentration corresponding to the $D A C$ to result in an intake numerically in excess of the $A L I$ and a dose in excess of the limit.

The computational procedures used by the ICRP can not be relied upon to preserve the numerical relationships between the primary and secondary limits. Note that while the maximum error of the rounding procedure is $50 \%$, this is a varying multiplicative factor which can be as much as two. Furthermore, deriving the $D A C$ from a value of the $A L I$ that might vary by a factor of two from the published value jeopardizes the relationship between these two secondary quantities.

\section{Mlustrative Example}

To illustrate the details in the calculation of the secondary limits, consider the data for the inhalation of Class $Y$ compounds of Sr-85 in Table 2. Column one of the table lists the organs and tissues for which dose coefficients, $h_{50, T}$, were computed in Publication 30. The numerical values of the coefficients are given in column two. The product of the coefficients (column two) and the applicable tissue weighting factors (column three) is tabulated in column four. The maximum value in column four, the maximum weighted dose equivalent, is $8.5810^{-10} \mathrm{~Sv} \mathrm{~Bq}$.-1 for the lung; the entry is highlighted by a double underline. Using the $10 \%$ rule, only organs and tissues with weighted dose equivalents larger than $10 \%$ of the maximum weighted dose equivalent, or $8.5810^{-11} \mathrm{~Sv} \mathrm{Bq^{-1 }}$, are retained in the computations. Inspection of column four indicates that the lung is the only tissue surviving the $10 \%$ rule. Thus, if one approximates the committed effective dose equivalent by the sum of the weighted committed dose equivalent of the tissues surviving the $10 \%$ rule then the committed effective dose equivalent for inhalation of Class $Y$ compounds of Sr-85 is $8.610^{-10} \mathrm{~Sv} \mathrm{~Bq} q^{-1}$ (this value is found in the Supplement to Publication 30).

If the $10 \%$ rule is not used, as in Federal Guidance Report 11, the committed effective dose equivalent is the sum of the underlined values of weighted committed dose equivalent in column four or $1.3610^{-9} S \nu B q^{-1}$. In Federal Guidance Report 11, dose coefficients are given to three digits of which only two were apparently considered significant by the ICRP. The additional digit can be viewed as a "guard" and the result of subsequent calculations using these data should be rounded to no more than two digits. 
The $A L I$ and $D A C$ for inhalation of Class $Y$ forms of Sr-85 calculated in the manner of ICRP Publication 30 , (i.e., with the $10 \%$ rule and rounding to a single digit), are

$$
\begin{aligned}
A L I & =\frac{0.05 \mathrm{~Sv}}{8.58 \times 10^{-10} \mathrm{SvBq^{-1 }}} \\
& =6 \times 10^{7} \mathrm{~Bq} \\
D A C & =\frac{0.05 \mathrm{~Sv}}{8.58 \times 10^{-10} \mathrm{~Sv} \mathrm{~Bq}{ }^{-1} 2400 \mathrm{~m}^{3}} \\
& =2 \times 10^{4} \mathrm{~Bq} \mathrm{~m}^{-3} .
\end{aligned}
$$

The corresponding values calculated without the $10 \%$ rule and with the $D A C$ calculated from the rounded $A L I$, rounded to 2 digits, are

$$
\begin{aligned}
A L I & =\frac{0.05 \mathrm{~Sv}}{1.36 \times 10^{-9} \mathrm{SvBq} \mathrm{B}^{-1}} \\
& =3.6 \times 10^{7} \mathrm{~Bq} \\
D A C & =\frac{3.6 \times 10^{7} \mathrm{~Bq}}{2400 \mathrm{~m}^{3}} \\
& =1.5 \times 10^{4} \mathrm{~Bq} \mathrm{~m}^{-3} .
\end{aligned}
$$

The combination of the $10 \%$ rule and the rounding procedure were responsible for almost a factor of two numerical uncertainty in the $A L I\left(610^{7}\right.$ vs $\left.3.610^{7} \mathrm{~Bq}\right)$. This example was selected because of the large effect of the $10 \%$ rule on the $A K I$. Other examples could be presented that would illustrate an even greater impact of the rounding procedure. 
Table 2. Committed Effective Dose Equivalent Coefficient for Inhalation of Class $\boldsymbol{Y}$ Forms of Sr-85

\begin{tabular}{|c|c|c|c|}
\hline Organ/Tissue & $h_{50, r}\left(S v B q^{-1}\right)$ & $w_{T}$ & $w_{T} h_{5 n I}\left(S v B q^{-1}\right)$ \\
\hline Gonads & 3.34E-10 & 0.25 & 8.35E-11 \\
\hline Breast & $4.65 \mathrm{E}-10$ & 0.15 & $\underline{6.97 \mathrm{E}-11}$ \\
\hline Lung & 7.15E-09 & 0.12 & $8.58 \mathrm{E}-10$ \\
\hline R. Marrow & $4.65 \mathrm{E}-10$ & 0.12 & $\underline{5.58 \mathrm{E}-11}$ \\
\hline B. Surface & $3.50 \mathrm{E}-10$ & 0.03 & $\underline{1.05 \mathrm{E}-11}$ \\
\hline Thyroid & $3.85 \mathrm{E}-10$ & 0.03 & $\underline{1.15 \mathrm{E}-11}$ \\
\hline \multicolumn{4}{|c|}{ Remainder Tissues ${ }^{1}$} \\
\hline Adrenals & 7.87E-10 & 0.06 & $\underline{4.72 \mathrm{E}-11}$ \\
\hline Bladder Wall & $1.11 \mathrm{E}-10$ & 0.06 & $6.66 \mathrm{E}-12$ \\
\hline St Wall & $6.59 \mathrm{E}-10$ & 0.06 & 3.95E-11 \\
\hline SI Wall & $3.78 \mathrm{E}-10$ & 0.06 & $2.27 \mathrm{E}-11$ \\
\hline ULI Wall & $5.87 \mathrm{E}-10$ & 0.06 & $3.52 \mathrm{E}-11$ \\
\hline LLI Wall & $9.12 \mathrm{E}-10$ & 0.06 & $5.47 \mathrm{E}-11$ \\
\hline Kidneys & 3.67E-10 & 0.06 & $2.20 E-11$ \\
\hline Liver & 7.71E-10 & 0.06 & $\underline{4.63 E-11}$ \\
\hline Pancreas & $9.03 \mathrm{E}-10$ & 0.06 & 5.42E-11 \\
\hline Spleen & $6.95 E-10$ & 0.06 & 4.17E-11 \\
\hline Thymus & $1.15 E-09$ & 0.06 & $\underline{6.90 \mathrm{E}-11}$ \\
\hline \multirow[t]{3}{*}{ Uterus } & $1.43 \mathrm{E}-10$ & 0.06 & 8.58E-12 \\
\hline & \multicolumn{2}{|c|}{$h_{50, E}$ with $10 \%$ rule } & $8.58 \mathrm{E}-10$ \\
\hline & \multicolumn{2}{|c|}{$h_{50.8}$ without $10 \%$ rule } & $1.36 \mathrm{E}-09$ \\
\hline
\end{tabular}

${ }^{1}$ Only the five tissues with the highest dose equivalent coefficient are retained. 


\section{REGULATORY ISSUES}

Regulatory Guide 8.34 (NRC 1992b) provides guidance on procedures considered acceptable in demonstrating compliance with the dose limits for the effective dose equivalent and the dose equivalent. The Guide defines the "total effective dose equivalent" as the sum of the "deep-dose equivalent" (from radiation sources external to the body) and the "committed effective dose equivalent" (from radionuclide intakes). The total dose equivalent to an organ is similarly defined as the sum of the "deep-dose equivalent" and the "committed dose equivalent" from the intake of radionuclides in a year. The guide lists various procedures that the NRC finds acceptable for calculation of the committed effective dose equivalent from inhalation and ingestion intakes. Four of the procedures use tabulated dosimetric information to serve as estimates of the committed effective dose equivalent per unit intake, $h_{50, E}$, and thus are of interest here. The procedures include:

1. Use dose coefficient, $h_{50, E}$, from Federal Guidance Report No. 11 (Eckerman et al., 1988). That report lists the committed effective dose and the committed dose equivalent coefficients for both inhalation and ingestion intakes of radionuclides. The effective dose equivalent $H_{50, E}$ is computed from knowledge of the intake $I$ of the radionuclide as

$$
\boldsymbol{H}_{50, \boldsymbol{E}}=I \boldsymbol{h}_{50, \boldsymbol{E}}
$$

where $h_{50, E}$ is the effective dose equivalent coefficient for the radionuclide.

2. Use the stochastic $A L I$ of Appendix B to 10 CFR Part 20 and knowledge of the intake $I$ of the radionuclide to compute the effective dose equivalent. The effective dose equivalent is

$$
H_{S 0, E}=I \frac{H_{\text {Limi, }, E}}{A L I_{S}}
$$

where $I$ is the intake and $H_{L i m i, E}$ is the annual limit on effective dose equivalent.

3. Use the DAC of Appendix B to 10 CFR Part 20, if the $A L I$ is based on the stochastic constraint, and express the intake in terms of the time-integrated airborne concentration. The effective dose equivalent is 


$$
\begin{aligned}
H_{50, E} & =\left[\frac{q}{2000} \int_{0}^{2000} C(t) d t\right]\left[\frac{H_{\text {Limi, }, E}}{q D A C}\right] \\
& =q \bar{C} \frac{H_{\text {Limit, }}}{q D A C} \\
& =I \frac{H_{\text {Limit, } E}}{q D A C}
\end{aligned}
$$

where $t$ is in hours, $C(t)$ is the airborne concentration, $D A C$ is the derived air concentration corresponding to the $A L I, q$ is the annual intake per unit airborne activity concentration (see Eq. 5), $C$ is the annual average activity concentration, and $\boldsymbol{H}_{\text {Limi, }, \boldsymbol{E}}$ is the annual limit on the effective dose equivalent.

4. Approximate the effective dose equivalent coefficient as the sum of the "weighted committed dose equivalents" listed in the Supplements of ICRP Publication 30. As discussed above, Committee 2 tabulated the "weighted committed dose equivalent to target organs or tissues per intake of unit activity" which were not eliminated by the $10 \%$ rule. These values can be summed to approximate the committed effective dose equivalent per unit intake. The effective dose equivalent $H_{50, E}$ is computed from the intake $I$ as

$$
H_{50, E}=I \sum_{T} w_{T} H_{50, T}
$$

where $w_{T} H_{50, T}$ is the weighted committed dose equivalent tabulated in the Supplements. Since the tabulations were limited by the $10 \%$ rule, the summation can only extend over tabulated values.

All four procedures are mathematically equivalent. However, the $10 \%$ rule and the rounding procedure used in tabulating the numerical values results in the procedures yielding different numerical values. Procedures one and four differ in that the former utilizes dose coefficients not based on the $10 \%$ rule and given to three digits while the latter is based only on the tissues surviving the $10 \%$ rule and is limited to two digits. Procedures two and three are the least desirable, from a numerical perspective, since the $A L I$ and $D A C$ were only given to a single digit - the extensive rounding limits the utility of these quantities in estimating effective dose equivalent.

Considering the manner in which the numerical values of the secondary quantities were derived, one cannot expect the procedures suggested in Regulatory Guide 8.34 to yield the same estimates of the effective dose equivalent. It is instructive to examine the extent to which the procedures approximate the effective dose equivalent coefficient. Table 3 compares, for a selected number of radionuclides, the values of the committed effective dose equivalent per unit intake as estimated by these procedures with the value from Federal Guidance Report 11. Examination of the table confirms that the suggested procedures are numerically inconsistent. The estimates based on the data from the Supplements of ICRP Publication 30, tabulated in column four, nearly always underestimate the actual value (column three) since the former includes the $10 \%$ rule. Estimates based on the secondary limits $A L I$ and $D A C$, the last two columns, may over- or underestimate the committed 
effective dose equivalent. Thus, the procedures recommended in Regulatory Guide 8.34 are of questionable utility in demonstration of regulatory compliance since they, in fact, result in numerically different values. 
Table 3. Values of the Committed Effective Equivalent per Unit Inhaled Activity $\left(S v B q^{-1}\right)$ per Regulatory Guide 8.34

\begin{tabular}{|c|c|c|c|c|c|}
\hline \multirow[b]{2}{*}{ Nuclide } & \multirow[b]{2}{*}{ Class } & \multirow[b]{2}{*}{ FGR $11^{1}$} & \multirow[b]{2}{*}{ ICRP $30^{2}$} & \multicolumn{2}{|c|}{ Computed from } \\
\hline & & & & $A L P^{3}$ & $D A C^{t}$ \\
\hline $\mathrm{H}-3$ & Vapor & 1.73E-11 & $1.7 \mathrm{E}-11$ & $2 E-11$ & $2 \mathrm{E}-11$ \\
\hline $\mathrm{Co}-60$ & $\begin{array}{l}W \\
Y\end{array}$ & $\begin{array}{l}8.94 \mathrm{E}-09 \\
5.91 \mathrm{E}-08\end{array}$ & $\begin{array}{l}8.0 \mathrm{E}-09 \\
4.1 \mathrm{E}-08\end{array}$ & $\begin{array}{l}8 E-09 \\
5 E-08\end{array}$ & $\begin{array}{l}7 \mathrm{E}-09 \\
4 \mathrm{E}-08\end{array}$ \\
\hline $\mathrm{Fe}-59$ & $\begin{array}{l}\text { D } \\
\text { W }\end{array}$ & $\begin{array}{l}4.00 \mathrm{E}-09 \\
3.30 \mathrm{E}-09\end{array}$ & $\begin{array}{l}4.0 \mathrm{E}-09 \\
2.7 \mathrm{E}-09\end{array}$ & $\begin{array}{l}5 E-09 \\
2 E-09\end{array}$ & $\begin{array}{l}4 \mathrm{E}-09 \\
3 \mathrm{E}-09\end{array}$ \\
\hline Sr-85 & $\begin{array}{l}\mathrm{D} \\
\mathrm{Y}\end{array}$ & $\begin{array}{l}5.18 \mathrm{E}-10 \\
1.36 \mathrm{E}-09\end{array}$ & $\begin{array}{l}5.2 \mathrm{E}-10 \\
8.6 \mathrm{E}-10\end{array}$ & $\begin{array}{l}5 E-10 \\
8 E-10\end{array}$ & $\begin{array}{l}5 E-10 \\
1 E-09\end{array}$ \\
\hline Sr-90 & $\begin{array}{l}\mathrm{D} \\
\mathrm{Y}\end{array}$ & $\begin{array}{l}6.47 \mathrm{E}-08 \\
3.51 \mathrm{E}-07\end{array}$ & $\begin{array}{l}6.2 \mathrm{E}-08 \\
3.4 \mathrm{E}-07\end{array}$ & $\begin{array}{l}6 \mathrm{E}-08 \\
5 \mathrm{E}-07\end{array}$ & $\frac{--.5}{3 E-07}$ \\
\hline $\mathrm{Zr}-95$ & $\begin{array}{l}D \\
W \\
Y\end{array}$ & $\begin{array}{l}6.39 \mathrm{E}-09 \\
4.29 \mathrm{E}-09 \\
6.32 \mathrm{E}-09\end{array}$ & $\begin{array}{l}5.2 \mathrm{E}-09 \\
3.5 \mathrm{E}-09 \\
4.9 \mathrm{E}-09\end{array}$ & $\begin{array}{l}5 E-09 \\
5 E-09 \\
5 E-09\end{array}$ & $\begin{array}{c}-- \\
3 E-09 \\
5 E-09\end{array}$ \\
\hline Mo-99 & $\begin{array}{l}\mathrm{D} \\
\mathrm{W}\end{array}$ & $\begin{array}{l}5.42 \mathrm{E}-10 \\
1.07 \mathrm{E}-09\end{array}$ & $\begin{array}{l}5.2 \mathrm{E}-10 \\
9.9 \mathrm{E}-10\end{array}$ & $\begin{array}{l}5 E-10 \\
1 \mathrm{E}-09\end{array}$ & $\begin{array}{l}5 E-10 \\
1 E-09\end{array}$ \\
\hline $\mathrm{I}-131$ & $\mathrm{D}$ & $8.89 \mathrm{E}-09$ & 8.8E-09 & $8 \mathrm{E}-09$ & -- \\
\hline Cs-137 & $\mathbf{D}$ & 8.63E-09 & 8.7E-09 & $8 \mathrm{E}-09$ & 1E-08 \\
\hline Ce-144 & $\begin{array}{l}\mathbf{W} \\
Y\end{array}$ & $\begin{array}{l}5.84 \mathrm{E}-08 \\
1.01 \mathrm{E}-07\end{array}$ & $\begin{array}{l}\text { 5.3E-08 } \\
\text { 9.5E-08 }\end{array}$ & $\begin{array}{l}6 \mathrm{E}-08 \\
1 \mathrm{E}-07\end{array}$ & $\begin{array}{l}5 E-08 \\
1 E-07\end{array}$ \\
\hline Ra-226 & $\mathbf{W}$ & $2.32 \mathrm{E}-06$ & 2.1E-06 & 2E-06 & $2 \mathrm{E}-06$ \\
\hline Th-232 & $\begin{array}{l}\mathbf{W} \\
\mathbf{Y}\end{array}$ & $\begin{array}{l}4.43 E-04 \\
3.11 E-04\end{array}$ & $\begin{array}{l}4.4 \mathrm{E}-04 \\
3.1 \mathrm{E}-04\end{array}$ & $\begin{array}{l}5 E-04 \\
2 E-04\end{array}$ & - \\
\hline U-234 & $\begin{array}{l}\mathrm{D} \\
\mathrm{W} \\
\mathbf{Y}\end{array}$ & $\begin{array}{l}7.37 E-07 \\
2.13 E-06 \\
3.58 E-05\end{array}$ & $\begin{array}{l}7.2 \mathrm{E}-07 \\
1.9 \mathrm{E}-06 \\
3.6 \mathrm{E}-05\end{array}$ & $\begin{array}{l}7 \mathrm{E}-07 \\
2 \mathrm{E}-06 \\
5 \mathrm{E}-05\end{array}$ & $\begin{array}{l}--- \\
2 E-06 \\
3 E-05\end{array}$ \\
\hline $\mathrm{Pu}-239$ & $\begin{array}{l}\mathbf{W} \\
\mathbf{Y}\end{array}$ & $\begin{array}{l}1.16 E-04 \\
8.33 E-05\end{array}$ & $\begin{array}{l}1.1 \mathrm{E}-04 \\
8.1 \mathrm{E}-05\end{array}$ & $\begin{array}{l}1 \mathrm{E}-04 \\
8 \mathrm{E}-05\end{array}$ & - \\
\hline Am-241 & $\mathbf{W}$ & $1.20 \mathrm{E}-04$ & 1.2E-04 & 1E-04 & --- \\
\hline
\end{tabular}

${ }^{1}$ From Table 2.1 of Eckerman, et al. (1988).

${ }^{2}$ Computed from Supplements to ICRP Publication 30.

${ }^{3}$ Computed as 0.05/ALIs using the $A L I$ from Publication 30.

${ }^{4}$ Computed as $0.05 / 2400 D A C$, if the $A L I$ is based on stochastic considerations.

${ }^{5} D A C$ not based on stochastic consideration. 


\section{RADON DECAY PRODUCTS}

Because of difficulties in calculating the dose to lung tissues from inhalation of the short-lived decay products of radon, a different type of secondary limit has been used for controlling such exposures (FRC 1967). The quantity, Working Level Month (WLM) - developed for use in regulating the exposure of underground uranium miners, has gradually gained application to other workers as well. In 1969, the previous $12 W L M$ guidance for annual exposures to the short-lived decay products of $\mathrm{Rn}-222$ was reduced, for a trial period, to $4 \mathrm{WLM}$. There apparently was not adequate basis for less stringent protection and the recommended 4 WLM limit remains in effect (EPA 1971a, 1971b).

The ICRP reviewed the epidemiological and dosimetric data for the two radon isotopes of concern. It recommended guidance for Rn-222 that is comparable to the $4 W L M$ value in use in the United States. It also concluded that the risk from inhalation of the short-lived decay products of $\mathrm{Rn}-220$ is about one-third that associated with $\mathrm{Rn}-222$ decay products (ICRP 1981b). This relationship was used in Federal Guidance Report No. 11 (Eckerman et al. 1988) to establish $12 W L M$ as the guidance for $\mathrm{Rn}-220$. The secondary quantities presented here are based on these guidelines.

The relationship between $\boldsymbol{W L M}$ and $\mathrm{Rn}-222$ equilibrium-equivalent concentration in the workplace is $0.00126 \mathrm{WLM}$ per $\mathrm{Bq} \mathrm{\textrm {m } ^ { - 3 }}$, assuming $2000 \mathrm{~h}$ per year at work and an equilibrium factor $\mathrm{F}$ of $40 \%$ (ICRP 1987) ${ }^{1}$. Thus $4 W L M$ corresponds to a Rn-222 concentration of $3200 B q \mathrm{~m}^{-3}$ or $8.610^{-8} \mu \mathrm{Ci} \mathrm{ml}^{-1}$. For $\mathrm{Rn}-220$ the relationship between $W L M$ and $\mathrm{Rn}-220$ equilibrium-equivalent concentration is $0.017 \mathrm{WLM}$ per $B q \mathrm{~m}^{-3}$ and thus the $12 W L M$ corresponds to an $\mathrm{Rn}-220$ concentration of $700 \mathrm{~Bq} \mathrm{~m}$ or $1.910^{-8} \mu \mathrm{Ci} \mathrm{ml}^{-1}$. The $D A C$ values as a function of equilibrium factor $F$ are given in Table 4 and shown graphically in Fig. 1. Note that Table 4 contains an entry for pure radon ( $F$ equal zero) although such exposure conditions are not typical of the workplace or the environment.

For public exposures and $\mathrm{Rn}-222$, the relationship between $W L M$ and $\mathrm{Rn}-222$ concentration is $0.0044 W L M$ per $B q \mathrm{~m}^{-3}$, assuming continuous exposure and an equilibrium factor of 0.4 . Thus

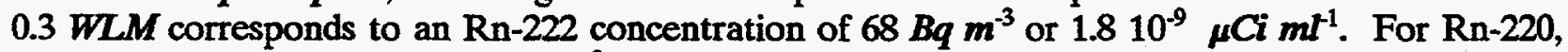
the relationship $0.059 W L M$ per $B q m^{-3}$ and the $1 W L M$ exposure limit yields $R n-220$ air concentration of $16 \mathrm{~Bq} \mathrm{m^{-3 }}$ or $4.610^{-10} \mu \mathrm{Ci} \mathrm{ml}^{-1}$.

\footnotetext{
1 The equilibrium-equivalent radon concentration of a non-equilibrium mixture of short-lived $\mathrm{Rn}$ daughters in air is that activity concentration of radon in radioactive equilibrium with its short-lived daughters that has the same potential $\alpha$-energy concentration as the non-equilibrium mixture. The "equilibrium factor $F^{\prime}$ is the ratio, often expressed as a percent, of the actual radon activity concentration to the equilibrium-equivalent radon concentration of the non-equilibrium mixture.
} 
Table 4. Equilibrium-equivalent radon derived air concentrations $(D A C)$ as a function of equilibrium.

\begin{tabular}{rcccc} 
& \multicolumn{2}{c}{$\mathrm{Rn}-220$} & \multicolumn{2}{c}{ Rn-222 } \\
\cline { 2 - 5 }$F(\%)$ & $\begin{array}{c}D A C \\
\left(B q m^{-3}\right)\end{array}$ & $\begin{array}{c}D A C \\
\left(\mu C i m^{-1}\right)\end{array}$ & $\begin{array}{c}D A C \\
\left(B q m^{-3}\right)\end{array}$ & $\begin{array}{c}D A C \\
\left(\mu C i l^{-1}\right)\end{array}$ \\
\hline 0.0 & $2.3 \mathrm{E}+05$ & $6.2 \mathrm{E}-06$ & $1.4 \mathrm{E}+05$ & $3.8 \mathrm{E}-06$ \\
1.0 & $3.1 \mathrm{E}+04$ & $8.4 \mathrm{E}-07$ & $1.2 \mathrm{E}+05$ & $3.1 \mathrm{E}-06$ \\
2.0 & $2.3 \mathrm{E}+04$ & $6.3 \mathrm{E}-07$ & $8.5 \mathrm{E}+04$ & $2.3 \mathrm{E}-06$ \\
4.0 & $1.2 \mathrm{E}+04$ & $3.2 \mathrm{E}-07$ & $3.8 \mathrm{E}+04$ & $1.0 \mathrm{E}-06$ \\
6.0 & $6.1 \mathrm{E}+03$ & $1.6 \mathrm{E}-07$ & $2.1 \mathrm{E}+04$ & $5.7 \mathrm{E}-07$ \\
8.0 & $3.6 \mathrm{E}+03$ & $9.6 \mathrm{E}-08$ & $1.6 \mathrm{E}+04$ & $4.2 \mathrm{E}-07$ \\
10.0 & $2.8 \mathrm{E}+03$ & $7.4 \mathrm{E}-08$ & $1.3 \mathrm{E}+04$ & $3.4 \mathrm{E}-07$ \\
20.0 & $1.4 \mathrm{E}+03$ & $3.8 \mathrm{E}-08$ & $6.3 \mathrm{E}+03$ & $1.7 \mathrm{E}-07$ \\
40.0 & $7.0 \mathrm{E}+02$ & $1.9 \mathrm{E}-08$ & $3.2 \mathrm{E}+03$ & $8.6 \mathrm{E}-08$ \\
60.0 & $4.6 \mathrm{E}+02$ & $1.2 \mathrm{E}-08$ & $2.1 \mathrm{E}+03$ & $5.7 \mathrm{E}-08$ \\
80.0 & $3.5 \mathrm{E}+02$ & $9.4 \mathrm{E}-09$ & $1.6 \mathrm{E}+03$ & $4.3 \mathrm{E}-08$ \\
100.0 & $2.8 \mathrm{E}+02$ & $7.5 \mathrm{E}-09$ & $1.3 \mathrm{E}+03$ & $3.4 \mathrm{E}-08$ \\
\hline & & & & \\
\hline
\end{tabular}




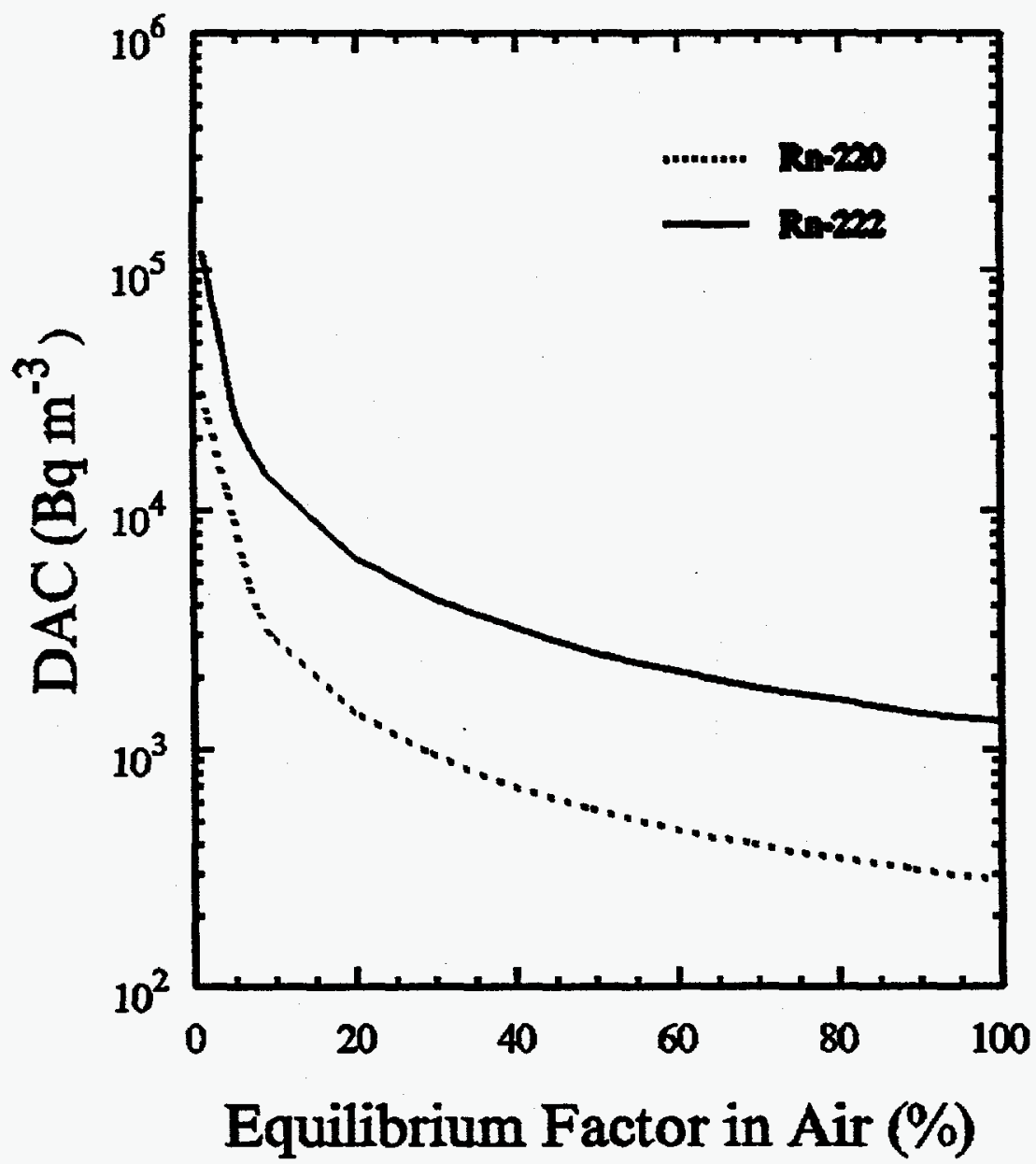

Figure 1. The equilibrium-equivalent DAC of radon for a non-equilibrium mixture of its short-lived daughters as a function of equilibrium. 


\section{RECOMMENDED VALUES FOR RADIONUCLIDE $A L I s$ and DACs}

A computational procedure was formulated to derive the radiation protection quantities in a manner that preserves their hierarchial relationships. The hierarchial relationship establishes the dose coefficients as the primary basis for estimation of dose with the $A L I$ and $D A C$ being of secondary importance. To establish the numerical relationship it was required that the secondary limits be derived without use of the $10 \%$ rule and that numerical rounding of values for publication must be performed in a manner consistent with the hierarchial relationships among the quantities. The computational procedure is briefly outlined below.

1. The dose coefficients for inhalation and ingestion intakes used in the calculations are those derived during preparation of Publication 30. Coefficients for selected radionuclides were published by Eckerman et al. (1981) and the coefficients determining the committed effective dose equivalent, including the committed dose equivalent for the organ or tissue encountering the nonstochastic constraint were published in Federal Guidance Report No. 11 (Eckerman et al. 1988), for inhalation and ingestion intakes, respectively. These data were retained in data files at Oak Ridge National Laboratory with an additional digit beyond the published data in the Supplements to Publication 30 and the $10 \%$ rule was not used in the computation of the committed effective dose equivalent.

The dose rate coefficients for submersion used in the calculations of this report are those contained in Federal Guidance Report 12 (Eckerman and Ryman 1993). These data are very similar to the data of Publication 30 but represent more extensive calculations of the organ doses from photons emitted within a semi-infinite cloud.

2. The intakes corresponding to the stochastic and non-stochastic constraints were computed using the above noted dose coefficients and applicable equations. The numerical values of the intakes corresponding to the two constraints on dose were truncated, by algorithm, to two digits ${ }^{2}$. The $A L I$ is the lesser of the two truncated values. If the two truncated values are equal then the $A L I$ is considered to be based on the stochastic constraint. When the $A L I$ is based on the nonstochastic constraint the intake corresponding to the stochastic constraint, $A I_{S}$, is tabulated in parentheses followed by the identity of the organ associated with the non-stochastic constraint. The algorithm truncates the numerical values; thus, if the $A L I$ is used to estimate dose it will not result in an underestimate.

3. For inhalation and ingestion, the $D A C$ is computed from the tabulated (truncated) value of the $A L I$ and is truncated, by algorithm, to two digits. The truncation ensures that the intake resulting from an exposure to a time-integrated airborne activity concentration of $2000 D A C-h$ will be less than the $A L I$.

For submersion, the annual average air concentrations corresponding to the stochastic and nonstochastic constraints are computed. These values are truncated to two digits and the $D A C$ is the lesser of the two values. If the $D A C$ is based on the non-stochastic constraint on either the lens of the eye or any other tissue, then the air concentration corresponding to the stochastic constraint is tabulated in parentheses followed by the identity of the organ associated with the non-stochastic constraint.

${ }^{2}$ The truncation operation retains only two nonzero digits. For example 1.416 becomes 1.4 and 1.993 becomes 1.9. The truncated value is always less than or equal to the original value. 
The dose coefficients of Federal Guidance Reports No. 11 and 12 were tabulated in SI units. The secondary quantities tabulated in this report were expressed in traditional units as in Appendix B to 10 CFR Part 20. The computations proceeded by first converting the dose coefficients to traditional units, within the software, and the calculations then continued with the dose limits also expressed in traditional units.

Appendix B of 10 CFR Part 20 contains guidance regarding the concentrations of radionuclides in effluent and sewage streams which was derived from the secondary quantities. As the numerical values of the secondary quantities have been revised here for completeness, the concentration data for the effluent and sewage streams have also been updated. The revised values are also given in Appendix A of this report. 


\section{DISCUSSION AND CONCLUSIONS}

A revised set of numerical guides, tabulated in Appendix A, has been established in a manner that preserves, in a numerical sense, the hierarchial relationship among the quantities and is consistent in content with Appendix B of 10 CFR Part 20. This was accomplished by not using the $10 \%$ rule of ICRP Publication 30 and by using a rounding (truncating) procedure that preserves the relationships among the quantities. Below are some observations regarding the new tabulations together with recommendations regarding the use of the revised data.

\section{Hierarchial Relationships:}

It was illustrated in Table 3 that the numerical data tabulated in Appendix B to 10 CFR Part 20 could not be used as suggested in Regulatory Guide 8.34 to estimate a unique value of the effective dose equivalent. That table illustrates the nature of the "numerical noise" in the existing Appendix B and shows that it is not possible to determine which of the procedures recommended in Regulatory Guide 8.34 might be more conservative. Thus, the user does not know $a$ priori which procedure will provide a conservative determination of compliance. In Table 5 we show that the revised numerical values presented in Appendix A of this report provide a consistent basis for assessing compliance. In

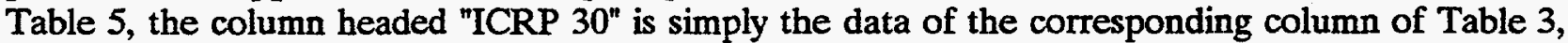
expressed, however, in conventional units. Ignoring that column for the moment, examination of the numerical values of the effective dose equivalent derived from the $A L I$ and the $D A C$, the data contained in the columns headed by " $A L I_{s}$ " and "DAC", are equal to or greater than the corresponding value in the column headed "FGR 11." Thus, use of the ALI or DAC from the tabulations of Appendix A of this report with the procedures suggested in Regulatory Guide 8.34 will not underestimate the effective dose equivalent. That is, use of the $A L I$ and $D A C$ will not indicate compliance when use of the committed effective dose equivalent of Federal Guidance 11 would suggest non-compliance. The data reflect a hierarchial relationship among the committed effective dose equivalent coefficient $h_{50, E}$, the $A L I$, and the $D A C$ for the radionuclide. The $A L I$ and $D A C$ provide a biased estimate of $h_{50, E}$, biased in a conservative manner with the $D A C$ potentially reflecting a slightly greater degree of conservatism.

The data of Appendix $\mathrm{A}$ are given to two digits to preserve the hierarchial relationship among the quantities without the excessive conservatism one would introduce if the data were rounded to a single digit. Since the data from Supplements to Publication 30, column headed "ICRP 30", nearly always underestimate the effective dose equivalent, they should not be used to demonstrate regulatory compliance.

\section{Chemical Form Considerations:}

The tabulation of Appendix A includes information on the dependence of the $A L I$ and $D A C$ on the chemical form of the inhaled or ingested radionuclide. In the case of inhalation intakes, the chemical forms for particulate matter are specified by the clearance classes $D, W$, and $Y$, while vapor forms are denoted by $V$. For ingested material, the chemical form considerations are represented by the numerical value assigned to the $f_{I}$ parameter. This parameter represents the fraction of the radioelement entering the stomach that is transferred to blood in the absence of radioactive decay. Since inhalation also results in the ingestion of material mechanically cleared from the respiratory tract, the tabulations of Appendix A indicate the value of $f_{1}$ used with each clearance class. In Appendix B to 10 CFR Part 20 the chemical form consideration for ingested materials was not included in the tabulation. 
It is important to note that the classification of materials with respect to inhalation (clearance classes and $f_{1}$ value) is a separate consideration from that for an ingestion intake. Considering the different physiological conditions within the respiratory tract and the gastrointestinal tract, it may be reasonable that the same value of $f_{1}$ is assigned to all three clearance classes despite the implication that Class $D$ materials are more soluble than Class $Y$ materials. Furthermore, it should be noted that for many situations little or no information is available to assign values to $f_{1}$ for inhalation intakes.

Care must also be taken in applying the rule of thumb that dose increases with increasing solubility as measured by clearance class and $f_{1}$ value; e.g., considering Class $D$ compounds to be more soluble than Class $W$. The biodistribution of the radionuclide depends, in part, upon its route of intake and its physical half-life while the dose to any organ or tissue depends upon the biodistribution and the nature of the emitted radiations; the effective dose equivalent depends on the organ/tissue dose equivalent as well as the assigned weighting factors. The $A L I s$ for various chemical forms of a radionuclide may be independent of the chemical form if the radionuclide has a short physical half-life (see the inhalation $A L I s$ for Class $D, W$, and $Y$ forms of Si-31). Three chemical forms were considered for ingestion of $\mathrm{Pu}$ with the $f_{1}$ values ranging from $10^{-5}$ to $10^{-3}$. For $\mathrm{Pu}-235$, the $A L I$ is the same for the three chemical forms because its short half-life results in the stochastic constraint limiting the intake based on the dose to the segments of the gastrointestinal tract. For longer-lived plutonium forms, the ingestion $A L I$ will exhibit the full dependence on $f_{1}$ and range over two orders of magnitude. An additional consideration that can further complicate the considerations is the ingrowth of decay products which contribute significantly to dose.

\section{Recommendations:}

The tabulated data of Appendix A form a consistent set of numerical data within the context of the radiation protection guidance of 10 CFR Part 20 and are presented in the format of Appendix $B$ to 10 CFR Part 20. Furthermore, these data preserve in a numerical sense the hierarchial relationships of the secondary radiation protection quantities such that they are consistent with the recommendations of Regulatory Guide 8.34.

The extraction of dosimetric data from the Supplements to Publication 30 should not be recommended as currently indicated in Regulatory Guide 8.34. This approach results in a consistent underestimate of the effective dose and thus, even in a screening type calculation, is hardly a useful estimator. With this exception, the other approaches recommended in the guide are valid when used with the data of Appendix A. 
Table 5. Values of the Committed Effective Equivalent per Unit Inhaled Activity ( $\mathrm{rem} \mu \mathrm{Ci}^{-1}$ ) per Regulatory Guide 8.3

\begin{tabular}{|c|c|c|c|c|c|}
\hline \multirow[b]{2}{*}{ Nuclide } & \multirow[b]{2}{*}{ Class } & \multirow[b]{2}{*}{ FGR $11^{1}$} & \multirow[b]{2}{*}{ ICRP $30^{2}$} & \multicolumn{2}{|c|}{ Computed from } \\
\hline & & & & $A L I s^{3}$ & $D A C^{4}$ \\
\hline H-3 & Vapor & $6.40 \mathrm{E}-05$ & $6.3 \mathrm{E}-05$ & $6.4 \mathrm{E}-05$ & $6.6 \mathrm{E}-05$ \\
\hline Co-60 & $\begin{array}{l}\mathbf{W} \\
\mathbf{Y}\end{array}$ & $\begin{array}{l}3.31 \mathrm{E}-02 \\
2.19 \mathrm{E}-01\end{array}$ & $\begin{array}{l}3.0 \mathrm{E}-02 \\
1.5 \mathrm{E}-01\end{array}$ & $\begin{array}{l}3.3 \mathrm{E}-02 \\
2.2 \mathrm{E}-01\end{array}$ & $\begin{array}{l}3.4 \mathrm{E}-02 \\
2.3 \mathrm{E}-01\end{array}$ \\
\hline Fe-59 & $\begin{array}{l}\mathrm{D} \\
\mathbf{W}\end{array}$ & $\begin{array}{l}1.48 \mathrm{E}-02 \\
1.22 \mathrm{E}-02\end{array}$ & $\begin{array}{l}1.5 E-02 \\
1.0 E-02\end{array}$ & $\begin{array}{l}1.5 \mathrm{E}-02 \\
1.3 \mathrm{E}-02\end{array}$ & $\begin{array}{l}1.6 \mathrm{E}-02 \\
1.3 \mathrm{E}-02\end{array}$ \\
\hline Sr-85 & $\begin{array}{l}\mathrm{D} \\
\mathrm{Y}\end{array}$ & $\begin{array}{l}1.91 \mathrm{E}-03 \\
5.03 \mathrm{E}-02\end{array}$ & $\begin{array}{l}1.9 \mathrm{E}-03 \\
3.2 \mathrm{E}-03\end{array}$ & $\begin{array}{l}1.9 \mathrm{E}-03 \\
5.1 \mathrm{E}-03\end{array}$ & $\begin{array}{l}2.1 \mathrm{E}-03 \\
5.1 \mathrm{E}-03\end{array}$ \\
\hline Sr-90 & $\begin{array}{l}\mathrm{D} \\
\mathrm{Y}\end{array}$ & $\begin{array}{c}2.39 E-01 \\
1.30 E+00\end{array}$ & $\begin{array}{c}2.3 E-01 \\
1.3 E+00\end{array}$ & $\begin{array}{c}2.5 E-01 \\
1.3 E+00\end{array}$ & $1 . \overline{4 \mathrm{E}+00}$ \\
\hline $\mathrm{Zr}-95$ & $\begin{array}{l}\mathrm{D} \\
\mathrm{W} \\
\mathrm{Y}\end{array}$ & $\begin{array}{l}2.37 \mathrm{E}-02 \\
1.59 \mathrm{E}-02 \\
2.33 \mathrm{E}-02\end{array}$ & $\begin{array}{l}1.9 \mathrm{E}-02 \\
1.3 \mathrm{E}-02 \\
1.8 \mathrm{E}-02\end{array}$ & $\begin{array}{l}2.4 \mathrm{E}-02 \\
1.6 \mathrm{E}-02 \\
2.4 \mathrm{E}-02\end{array}$ & $\begin{array}{c}-\overline{-}-\overline{\mathrm{E}-02} \\
2.4 \mathrm{E}-02\end{array}$ \\
\hline Mo-99 & $\begin{array}{l}\text { D } \\
\text { W }\end{array}$ & $\begin{array}{l}2.00 \mathrm{E}-03 \\
3.97 \mathrm{E}-03\end{array}$ & $\begin{array}{l}1.9 \mathrm{E}-03 \\
3.7 \mathrm{E}-03\end{array}$ & $\begin{array}{l}2.1 \mathrm{E}-03 \\
4.2 \mathrm{E}-03\end{array}$ & $\begin{array}{l}2.1 \mathrm{E}-03 \\
4.2 \mathrm{E}-03\end{array}$ \\
\hline $\mathrm{I}-131$ & D & $3.29 \mathrm{E}-02$ & 3.3E-02 & 3.3E-02 & - \\
\hline Cs-137 & $\mathbf{D}$ & 3.19E-02 & $3.2 \mathrm{E}-02$ & 3.3E-02 & $3.4 \mathrm{E}-02$ \\
\hline Ce-144 & $\begin{array}{l}\mathbf{W} \\
\mathbf{Y}\end{array}$ & $\begin{array}{l}2.16 \mathrm{E}-01 \\
3.75 \mathrm{E}-01\end{array}$ & $\begin{array}{l}2.0 E-01 \\
3.5 E-01\end{array}$ & $\begin{array}{l}2.2 \mathrm{E}-01 \\
3.8 \mathrm{E}-01\end{array}$ & $\begin{array}{l}2.2 \mathrm{E}-01 \\
3.9 \mathrm{E}-01\end{array}$ \\
\hline Ra-226 & $\mathbf{W}$ & $8.57 \mathrm{E}+00$ & $7.8 \mathrm{E}+00$ & $8.6 \mathrm{E}+\infty 0$ & $8.7 \mathrm{E}+00$ \\
\hline $\mathrm{Th}-232$ & $\begin{array}{l}\text { W } \\
Y\end{array}$ & $\begin{array}{l}1.64 E+03 \\
1.15 E+03\end{array}$ & $\begin{array}{l}1.6 E+03 \\
1.1 E+03\end{array}$ & $\begin{array}{l}1.7 \mathrm{E}+03 \\
1.2 \mathrm{E}+03\end{array}$ & - \\
\hline U-234 & $\begin{array}{l}\mathrm{D} \\
\mathrm{W} \\
\mathrm{Y}\end{array}$ & $\begin{array}{l}2.73 E+00 \\
7.89 E+00 \\
1.33 E+02\end{array}$ & $\begin{array}{l}2.7 E+00 \\
7.0 E+00 \\
1.3 E+00\end{array}$ & $\begin{array}{l}2.8 E+00 \\
7.9 E+00 \\
1.4 E+02\end{array}$ & $\begin{array}{c}8.0 \mathrm{E}+00 \\
1.4 \mathrm{E}+02\end{array}$ \\
\hline Pu-239 & $\begin{array}{l}\mathbf{W} \\
\mathbf{Y}\end{array}$ & $\begin{array}{l}4.30 E+02 \\
3.08 E+02\end{array}$ & $\begin{array}{l}4.1 E+02 \\
3.0 E+02\end{array}$ & $\begin{array}{l}4.5 E+02 \\
3.1 E+02\end{array}$ & - \\
\hline Am-241 & W & $4.43 E+02$ & $4.4 E+02$ & $4.5 E+02$ & - \\
\hline
\end{tabular}

${ }^{1}$ From Table 2.1 of Eckerman, et al. (1988).

${ }^{2}$ Computed from Supplements to ICRP Publication 30.

${ }^{3}$ Computed as 5.0/ALIs using the $A L I$ from Appendix A.

${ }^{4}$ Computed as $5.0 / 2.4 \times 10^{9} D A C$, if the $A L I$ is based on stochastic considerations. 


\section{REFERENCES}

K.F. Eckerman, M.R. Ford, and S.B. Watson (1981). Internal Dosimetry Data and Methods of the ICRP - Part 2, Vol 1: Committed Dose Equivalent and Secondary Limits, ORNL/NUREG/TM-433/V1 (Oak Ridge National Laboratory, Oak Ridge, TN).

K.F. Eckerman, A.B. Wolbarst, and A.C.B. Richardson (1988). Limiting Values of Radionuclide Intake and Air Concentration and Dose Conversion Factors for Inhalation, Submersion, and Ingestion, Federal Guidance Report No. 11, EPA-520/1-88-020 (U.S. Environmental Protection Agency, Washington, DC).

K.F. Eckerman and J.C. Ryman (1993). External Exposure to Radionuclides in Air, Water, and Soil, Federal Guidance Report No. 12, EPA-402-R-93-081 (U.S. Environmental Protection Agency, Washington, DC).

EPA (1971a). Environmental Protection Agency, "Underground Mining of Uranium Ore, Radiation Protection Guidance for Federal Agency," Federal Register 36, No. 101, 9480.

EPA (1971b). Environmental Protection Agency, "Underground Mining of Uranium Ore, Radiation Protection Guidance for Federal Agency," Federal Register 36, No. 132, 12921.

EPA (1987). Environmental Protection Agency, "Radiation Protection Guidance to Federal Agencies for Occupational Exposures," Federal Register 52, No. 17, 2822; with corrections published in the Federal Registers of Friday, January 30, and Wednesday, February 4, 1987.

FRC (1967). Federal Radiation Council, "Radiation Protection Guidance for Federal Agencies," Federal Register 32, No. 147, 11183.

ICRP (1975). International Commission on Radiological Protection, Report of the Task Group on Reference Man, ICRP Publication 23 (Pergamon Press, New York).

ICRP (1977). International Commission on Radiological Protection, "Recommendations of the International Commission on Radiological Protection," ICRP Publication 26, Annals of the ICRP Vol. 1, No. 3 (Pergamon Press, New York).

ICRP (1979). International Commission on Radiological Protection, "Limits of Intake by Worker," ICRP Publication 30, Part 1, Annals of the ICRP Vol. 2, No. $3 / 4$ (Pergamon Press, New York).

ICRP (1980). International Commission on Radiological Protection, "Limits of Intake by Worker," ICRP Publication 30, Part 2, Annals of the ICRP Vol. 4, No. 3/4 (Pergamon Press, New York).

ICRP (1981a). International Commission on Radiological Protection, "Limits of Intake by Worker," ICRP Publication 30, Part 3, Annals of the ICRP Vol 6, No. 2/3 (Pergamon Press, New York).

ICRP (1981b). International Commission on Radiological Protection, "Limits of Inhalation of Radon Daughters by Worker," ICRP Publication 32, Annals of the ICRP Vol. 6, No. 1 (Pergamon Press, New York). 
ICRP (1987). International Commission on Radiological Protection, "Lung Cancer Risk from Indoor Exposures to Radon Daughters," ICRP Publication 50, Annals of the ICRP Vol. 17, No. 1 (Pergamon Press, New York).

ICRP (1988). International Commission on Radiological Protection, "Limits of Intake by Worker: An Addendum," ICRP Publication 30, Part 4, Annals of the ICRP Vol. 19, No. 4 (Pergamon Press, New York).

NRC (1992a). Standards for Protection Against Radiation, Title 10 Part 20 Code of Federal Regulations. (U.S. Government Printing Office, Washington, DC).

NRC (1992b). Monitoring Criteria and Methods to Calculate Occupational Radiation Dose. Regulatory Guide 8.34. (U.S. Nuclear Regulatory Commission, Washington, DC).

J.W. Poston, Jr. and J.W. Poston, Sr. (1992). "Implementation of 10 CFR 20: Potential Impacts on Internal Dose Assessment Programs," Radiat. Prot. Management 9: September/October.

J.R. Windham, K.J. Kearfott, and F.J. Mis (1994). "Discrepancies in Committed Effective Dose Equivalents Calculated Using U.S. Nuclear Regulatory Commission Regulatory Guide 8.34," Health Phys. 67(5):486-494. 


\section{APPENDIX A \\ Recommended Values for the Quantities in Appendix B of 10 CFR Part 20}

\section{Introduction}

This appendix presents values for the radiation protection quantities in the format of Appendix $B$ to 10 CFR Part 20. As such, the discussion here follows that of 10 CFR Part 20; in particular, we retain the structure of Appendix B with respect to data tabulations, including the use of traditional units. The data are presented in three tables numbered in the manner of Appendix B to 10 CFR Part 20. We inciude an additional table, Table IV, which lists for each radionuclide the chemical form corresponding to the clearance class and $\mathrm{f}_{1}$ value for which $A L I$ or $D A C$ values are given in Table $I$. The $A L I S$ and $D A C s$ for inhalation are given for an aerosol with an activity median aerodynamic diameter $(A M A D)$ of $1 \mu \mathrm{m}$ and for four classes $(D, W, Y$, and $V)$ of radioactive material. The first three classes refer to the retention time within the pulmonary region of the lung of the deposited aerosol. Class $V$ refers to the vapor form of selected radioelements. The classification by puimonary retention applies to clearance half-times ranges of less than 10 days for $D$, of 10 to 100 days for $W$, and of greater than 100 days for $Y$. The class $\left(D, W, Y\right.$, or $V$ given in the column headed "Class $/ \mathrm{f}_{1}$ " applies only to the inhalation $A L I s$ and DACs given in Table $I$. The $f_{1}$ parameter denotes the fraction of the material entering the gastrointestinal tract that would be transferred to body fluids in the absence of radioactive decay. The $A L I s$ for ingestion are characterized by the value of the $f_{1}$ parameter that are seen in Table IV and Table I.

\section{Numerical Notation}

The numerical values in Tables I, II, III, and IV are presented in the computer " $\mathrm{E}^{n}$ notation when necessary. In this notation the entry $8.1 \mathrm{E}-05$ represents the number $8.1 \times 10^{-5}$ and similarly $2.9 \mathrm{E}+04$ represents $2.9 \times 10^{4}$.

\section{Table I}

Note that the entries in the columns of Table I, captioned "Inhalation" and "Ingestion," are applicable to occupational exposure to radioactive material.

The $A L I S$ in Table I are the annual intakes of the radionuclides by an adult male reference individual, hereafter designated "Reference Man," that would result in either (1) a committed effective dose equivalent of $5 \mathrm{rem}$ (stochastic $A L I$ ) or (2) a committed dose equivalent of $50 \mathrm{rem}$ to an organ or tissue (non-stochastic $A L n$ ). Due to irradiation of the organs and tissues of the body, an intake of a quantity of a radionuclide corresponding to the stochastic $A L I$ is considered comparable to the risk associated with deep dose equivalent to the whole body of $5 \mathrm{rem}$. The derivation includes multiplying the committed dose equivalent to an organ or tissue by a weighting factor, $w_{T}$. This weighting factor is the proportion of the risk of stochastic effects resulting from irradiation of the organ or tissue $T$ to the total risk of stochastic effects when the whole body is irradiated uniformly. The values of $w_{T}$ are listed in Table 1; see also $\$ 20.1003$ of 10 CFR Part 20. The non-stochastic ALIs were derived to avoid non-stochastic effects, such as prompt damage to tissue or reduction in organ function. 
A value of $w_{x}=0.06$ is applicable to each of the five organs or tissues in the "remainder" category receiving the highest dose equivalents, and the dose equivalents of all other remaining tissues may be disregarded. The following parts of the GI tract - stomach, small intestine, upper large intestine, and lower large intestine - are treated as separate organs.

Note that the dose equivalent for extremities (hands and forearms, feet and lower legs), skin, and lens of the eye are not considered in computing the committed effective dose equivalent, but are subject to limits that must be met separately.

When an $A L I$ is defined by the stochastic dose limit, this vaiue alone is given. When an $A L I$ is determined by the non-stochastic dose limit, the $A L I$ for the stochastic limit is shown in parentheses followed by name of the organ or tissue for which the non-stochastic limit applies. (Abbreviated organ or tissue designations are: $L L I$ wall denotes the wall of the lower large intestine; St wall is the wall of the stomach; and BSurface denotes bone surface.)

Use of the $A L I$ (first value listed) will ensure that non-stochastic effects are avoided and that the risk of stochastic effects is limited to an acceptably low value. If a situation involves a radionuclide for which the non-stochastic $A L I$ is limiting and its use is considered unduly conservative, then the stochastic $A L I$ can be used to determine the committed effective dose equivalent. However, it will be necessary also to ensure that the 50-rem dose equivalent limit for any organ or tissue is not exceeded by the sum of the external deep dose equivalent plus the internal committed dose to that organ (not the effective dose). For the case where there is no external dose contribution, this would be demonstrated if the sum of the fractions of the nonstochastic $A L I s\left(A L I_{N S}\right)$ that contribute to the committed dose equivalent to the organ receiving the highest dose does not exceed unity, i.e.,

$$
\sum \frac{\text { intake }\left(\mu C_{i}\right) \text { of radionuclide }}{A L I_{N S} \text { for radionuclide }} \leq 1 \text {. }
$$

If there is an external deep dose equivalent contribution of $H_{d}$ then the above sum must be less than $1-\left(H_{d} / 50\right)$ instead of 1.0.

The derived air concentration (DAC) values are intended to control chronic occupational exposures. The relationship between the DAC and the $A L I$ is given by

$$
\begin{aligned}
\text { DAC } & =\frac{A L I}{2000 \text { hour } 60 \text { minutes/hour } 2 \times 10^{4} \mathrm{~m} / \text { minute }} \\
& =\frac{A L I}{2.4 \times 10^{9}} \mu \mathrm{Ci} / \mathrm{ml},
\end{aligned}
$$

where $2 \times 10^{4} \mathrm{ml}$ is the volume of air breathed per minute at work by "Reference Man" under working conditions of "light work." In the case of tritiated water vapor, considerations are given to the intakes via both dermal (skin) absorption and inhalation. The total intake is assumed to be 1.5 times that due to inhalation alone. Thus, for tritiated water vapor, the $D A C$ is the quotient of the $A L I$ and $3.6 \times 10^{\circ}$. 
The $D A C$ values relate to one of the two modes of exposure: either external submersion or the internal committed dose equivalent resulting from inhalation of radioactive materials. Derived air concentrations based upon submersion are for immersion in a semi-infinite cloud of uniform concentration and apply to each radionuclide separately.

The $A L I$ and $D A C$ values relate to exposure to the single radionuclide named, but also include contributions for the ingrowth of any daughter radionuclide produced in the body by the decay of the parent. However, intakes that include both the parent and daughter radionuclides should be treated by the general method appropriate for mixtures.

Table II

The columns in Table II of this appendix captioned "Effluent" are applicable to the assessment and control of dose to the public, particularly in the implementation of the provisions of $\$ 20.1303$ of 10 CFR Part 20. The concentration values given in Table II are equivalent to the radionuclide concentration which, if inhaled or ingested continuously over the course of a year, would produce a total effective dose equivalent of $0.05 \mathrm{rem}$.

Consideration of the non-stochastic limits has not been inciuded in deriving the air and water effluent concentration limits because non-stochastic effects are presumed not to occur at the dose levels established for individual members of the public. In the case of radionuclide for which the nonstochastic limit governed the occupational $D A C$, the stochastic $A L I$ was used in deriving the corresponding airborne effluent limit in Table II.

The air concentration values listed in Table II were derived by one of two methods as outlined in Appendix B to 10 CFR Part 20. For those radionuclides for which the stochastic limit governs, the occupational stochastic inhalation $A L I$ was divided by $2.410^{9} \mathrm{ml}$, relating the inhalation $A L I$ to the $D A C$, as explained above, and then divided by a factor of 300 . The factor of 300 includes the following components: a factor of 50 to relate the 5-rem annual occupational dose limit to the 0.1-rem limit for members of the public; a factor of 3 to adjust for the difference in exposure time and the inhalation rate for a worker or for members of the public; and a factor of 2 to adjust the occupational values (derived for adults) so that they are applicable to children.

For radionuclides for which submersion (external dose) is limiting, air concentration values in Table II were obtained by dividing the occupational DAC of Table I by 219 . The factor 219 is composed of a factor of 50 , as noted above, and a factor of 4.38 relating an annual occupational exposure for 2000 hours to a continuous annual exposure of 8760 hours. Note that an additional factor of 2 for age considerations was not consider warranted for submersion case in Appendix B to 10 CFR Part 20.

The concentrations in water listed in Table II were derived by taking the most restrictive value of the stochastic $A L I$ for ingestion listed in Table I and dividing by $7.310^{7}$. The factor $7.310^{7} \mathrm{ml}$ includes the following components: the factors of 50 and 2 described above and a factor of $7.310^{5} \mathrm{ml}$ which is the annual water intake of "Reference Man."

Note 5 of this appendix provides groupings of radionuclides that are applicable to unknown mixtures of radionuclides. These groupings (including occupational inhalation $A L I s$ and $D A C s$, air and water effluent concentrations and sewerage) require demonstrating that the most limiting radionuclides in 
successive classes are absent. The limit for the unknown mixture is defined when the presence of one of the listed radionculides cannot be definitely excluded either from knowledge of the radionuclide composition of the source or from actual measurements.

\section{Table III}

The monthly average concentration for release to sanitary sewers is applicable to the provisions in $\$ 20.2003$ of Appendix B to 10 CFR Part 20. The concentration values were derived by taking the most restrictive value of the stochastic $A L I$ for ingestion intakes in Table I and dividing by $7.310^{6} \mathrm{ml}$. This factor is composed of a factor of $7.310^{5} \mathrm{ml}$, the annual water intake by "Reference Man," and. a factor of 10 , such that the concentrations, if the sewage released by the licensee were the only source of water ingested by 'Reference Man' during a year, would result in a committed effective dose equivalent of $0.5 \mathrm{rem}$. 


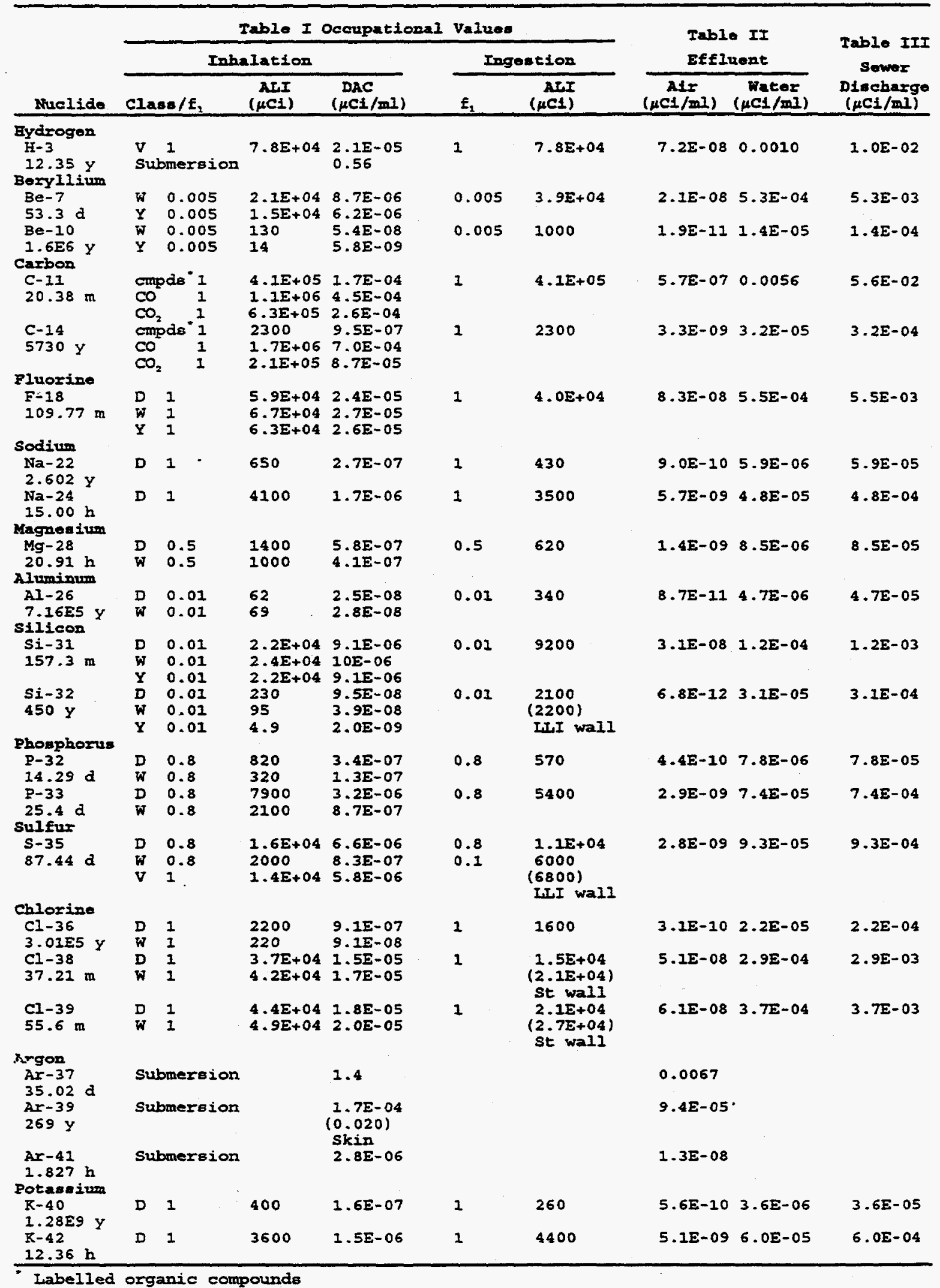




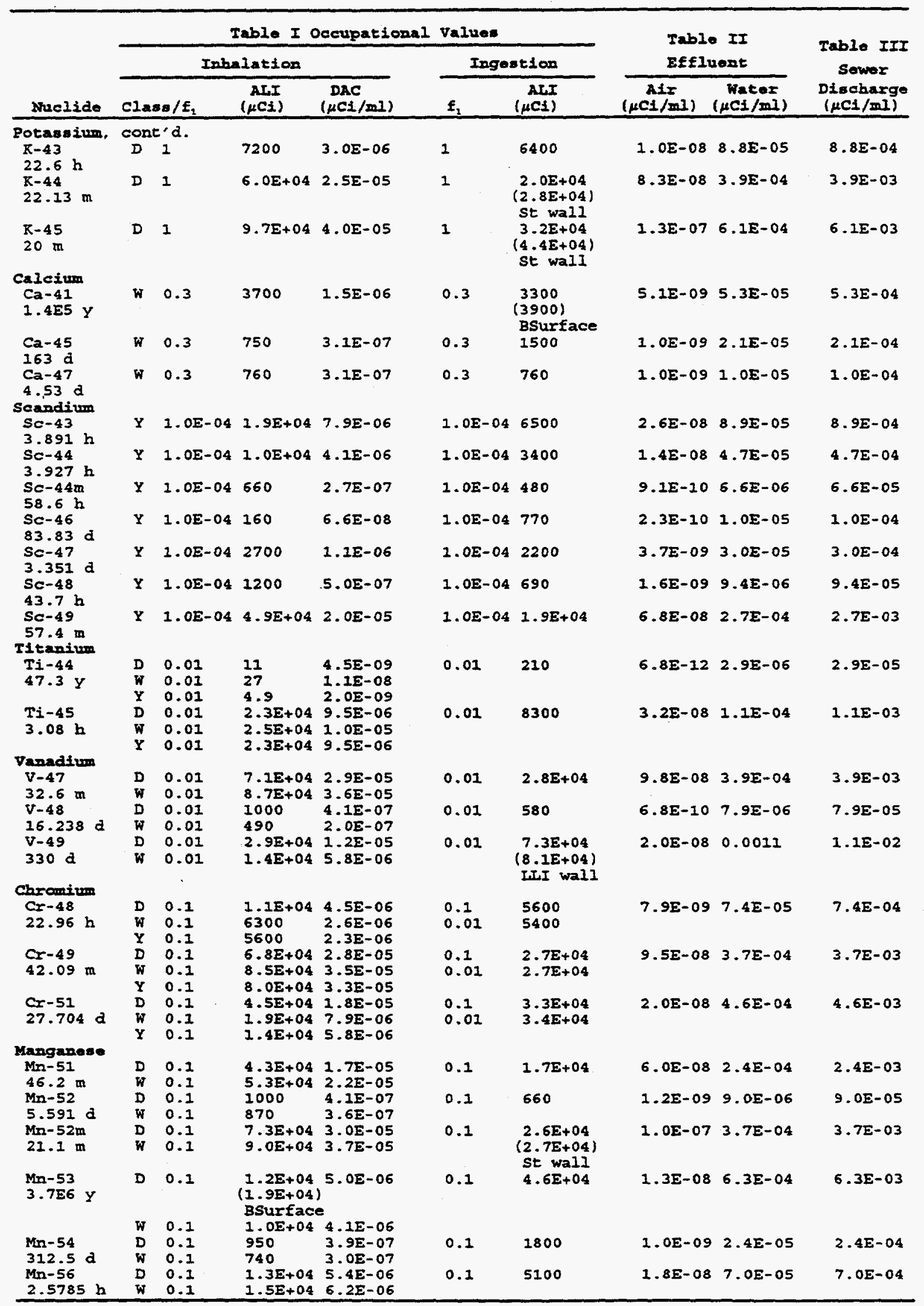




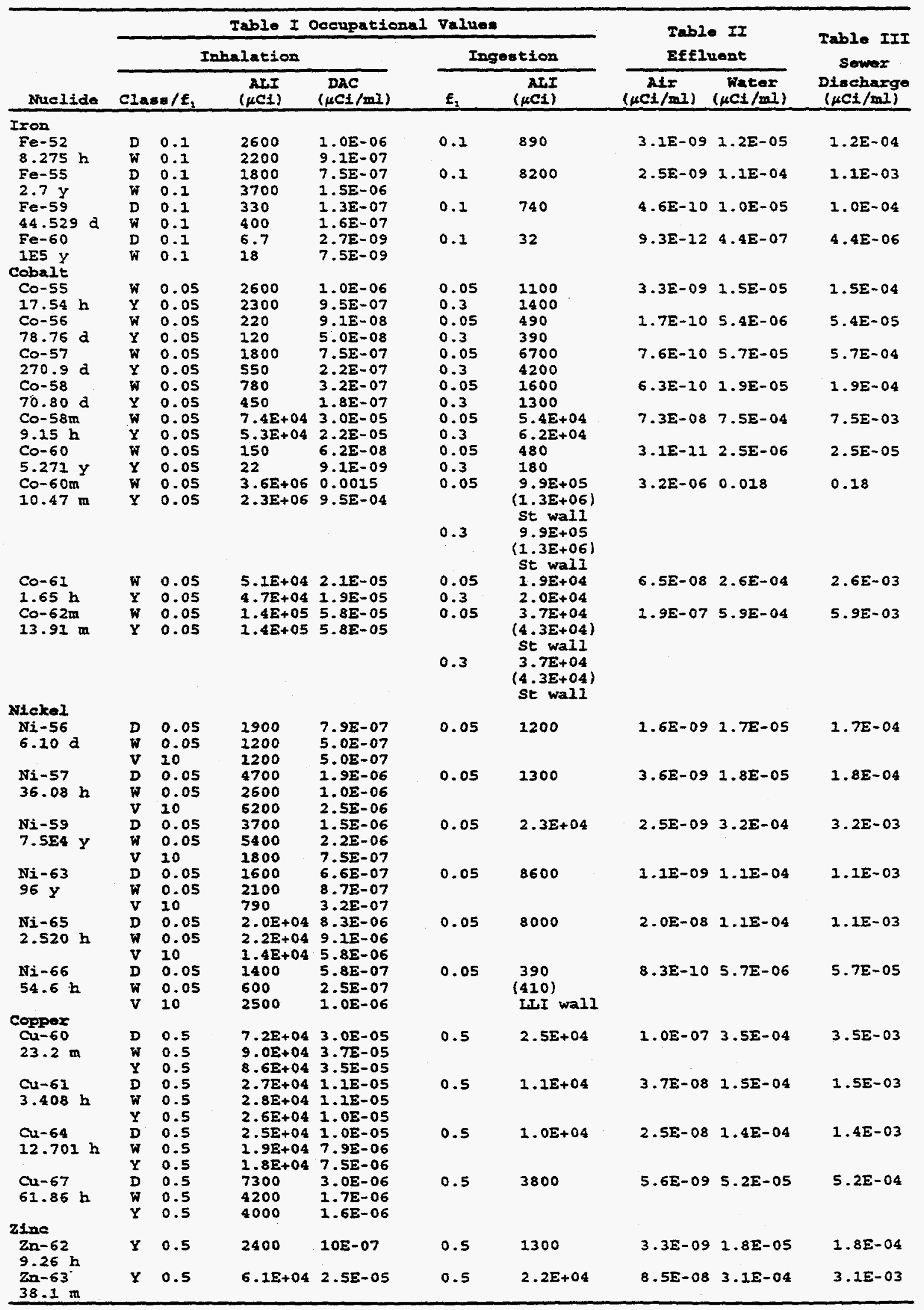




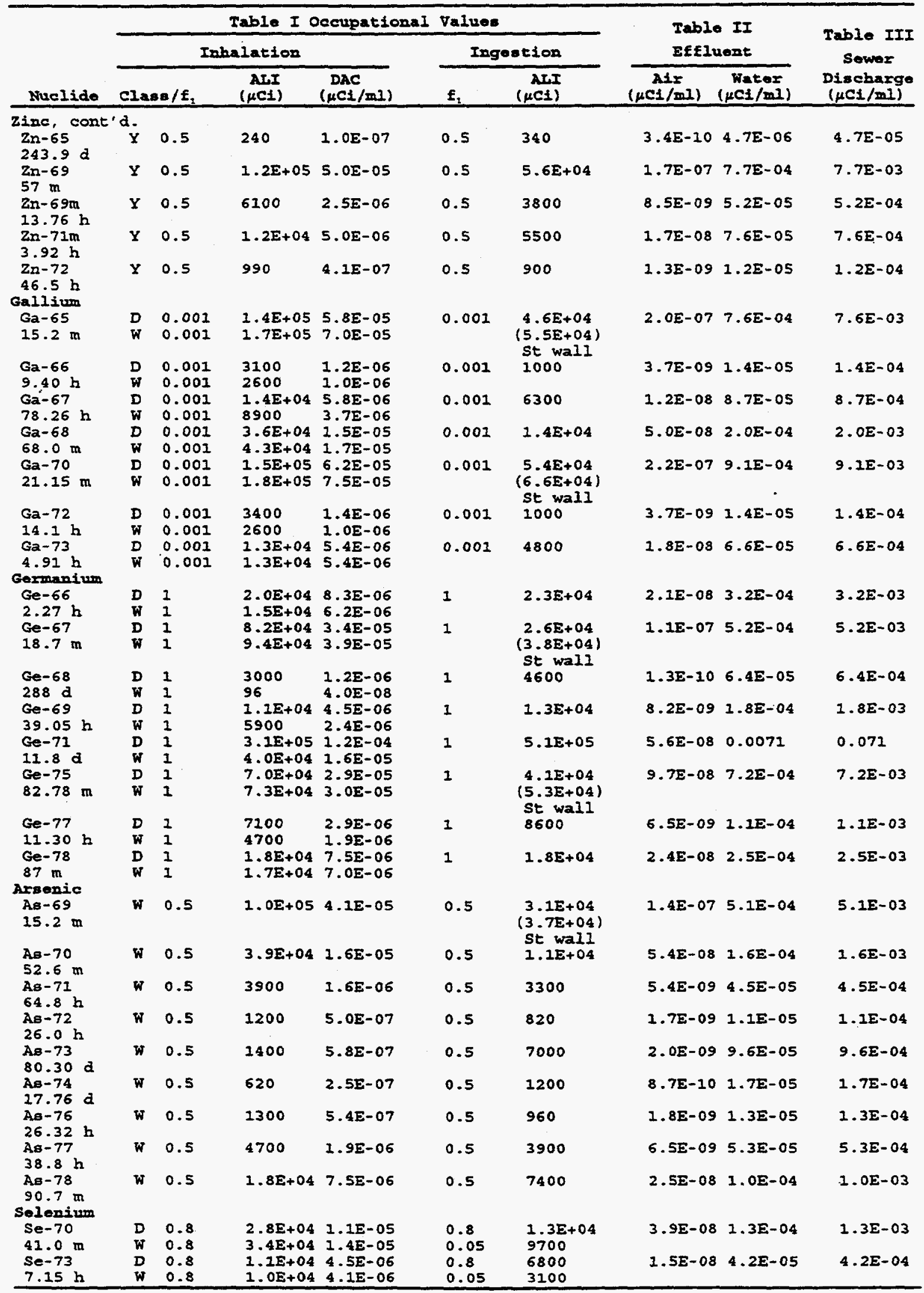




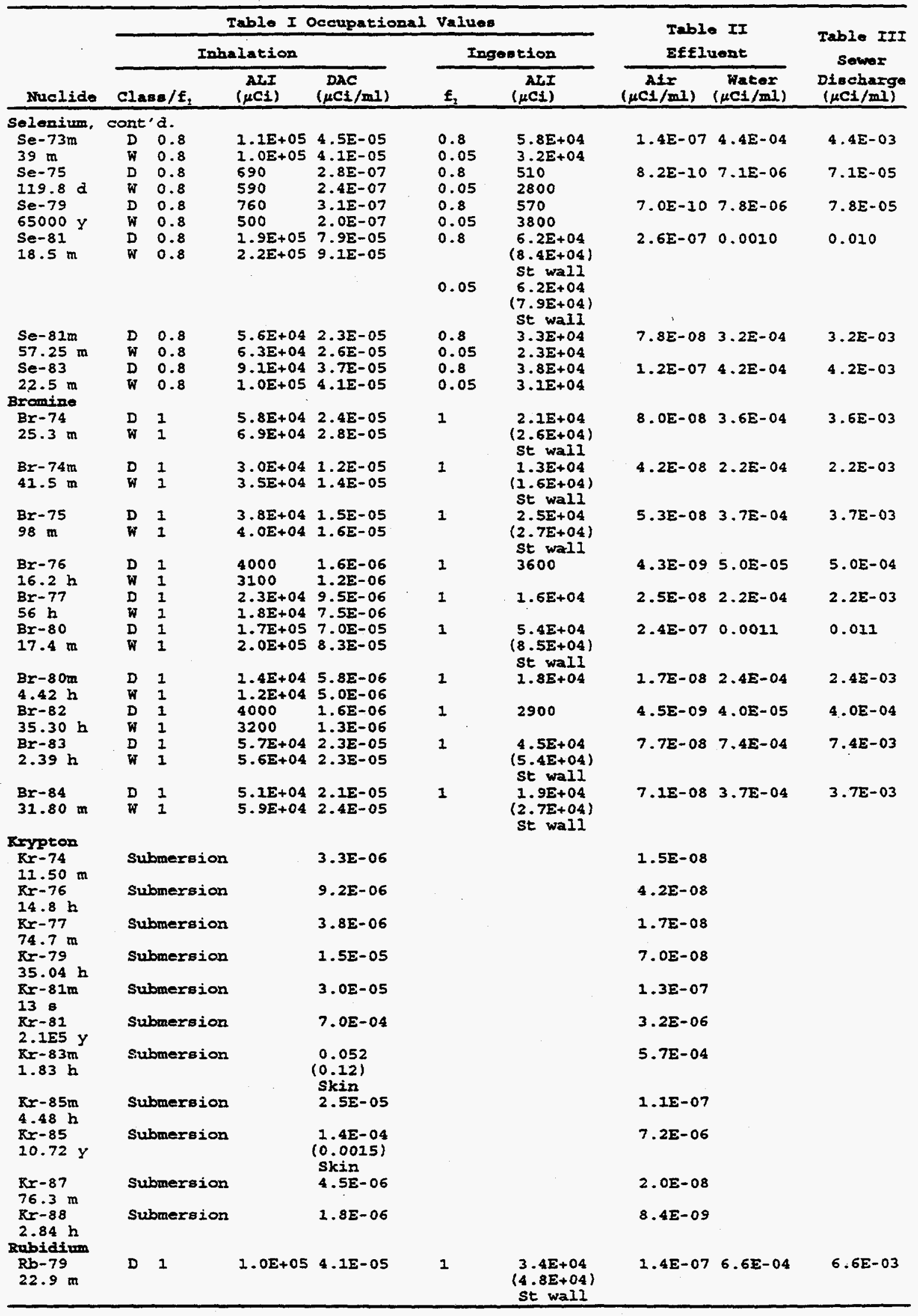




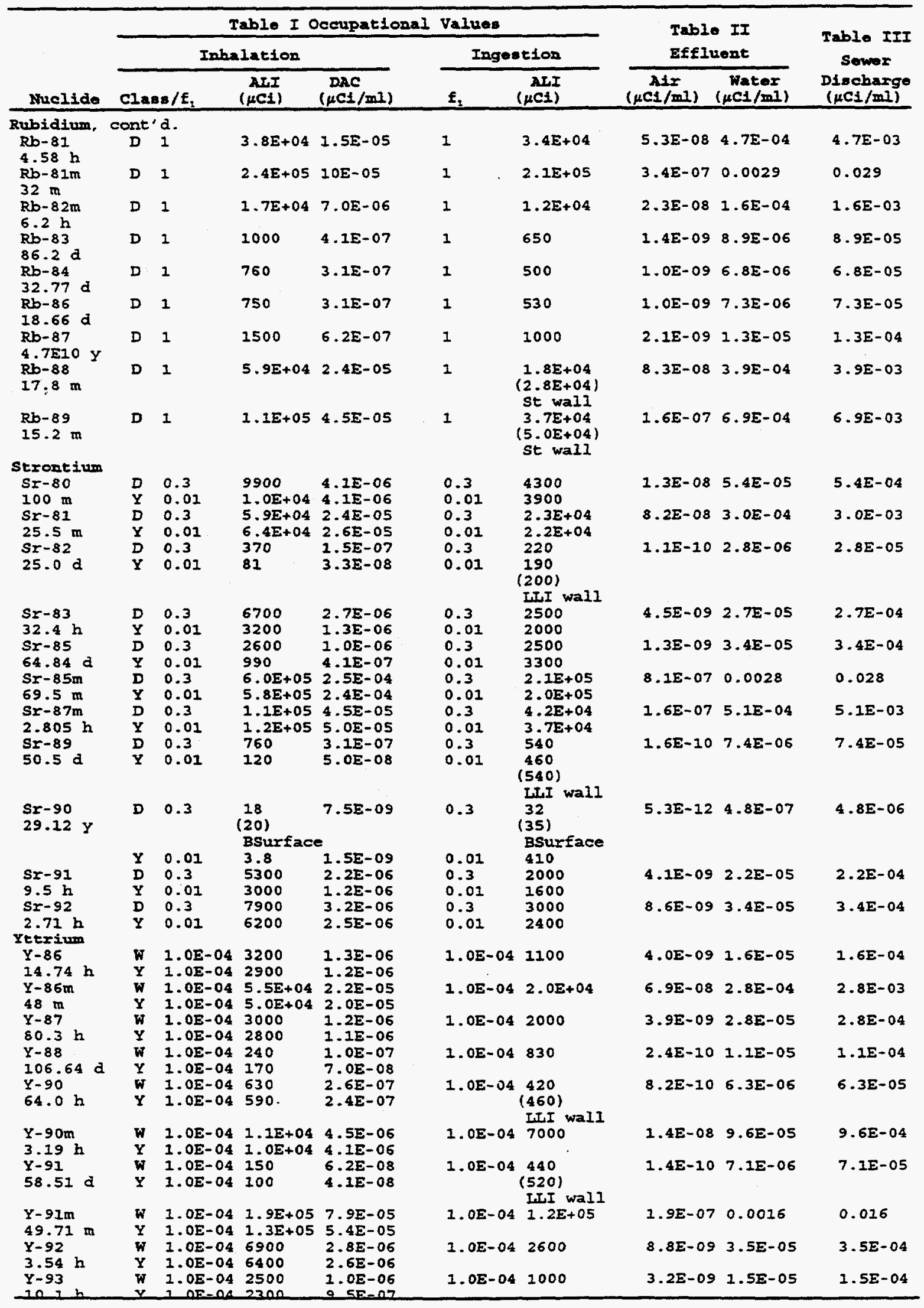




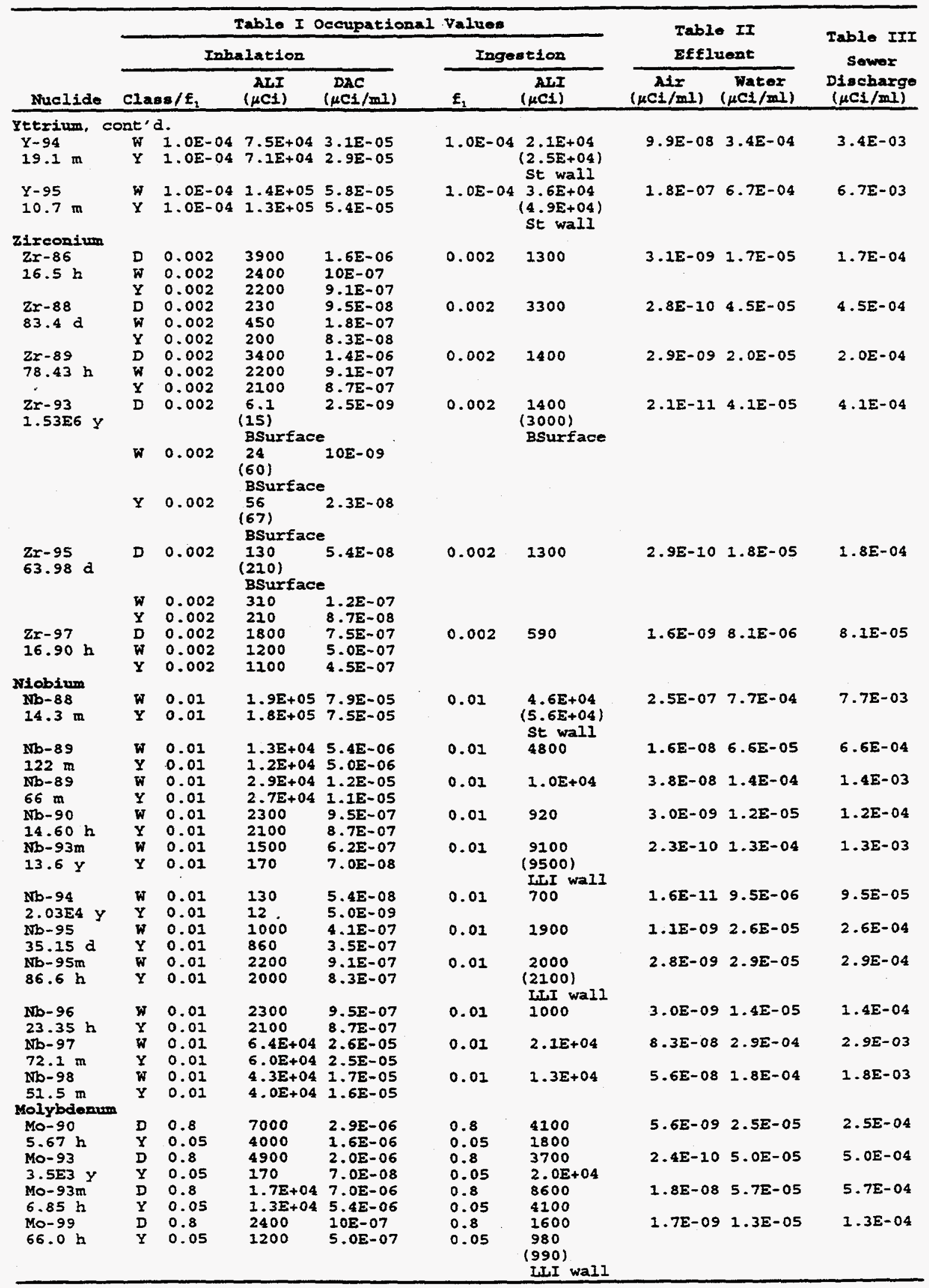




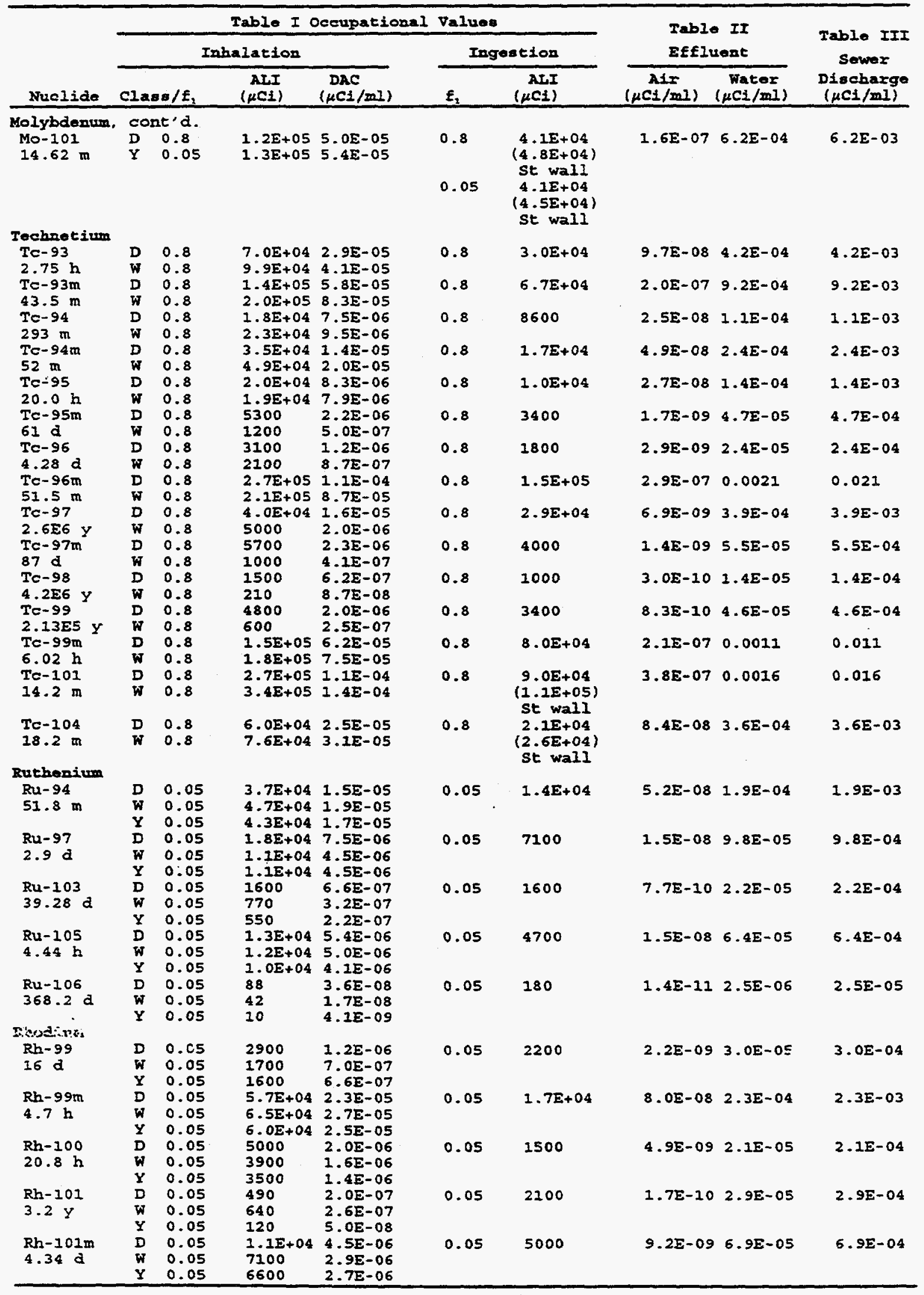




\begin{tabular}{|c|c|c|c|c|c|c|c|c|c|}
\hline \multirow[b]{3}{*}{ Nuclide } & \multirow{2}{*}{\multicolumn{4}{|c|}{ Table I Occupation }} & \multirow{2}{*}{\multicolumn{2}{|c|}{$\begin{array}{l}\text { Valuea } \\
\text { Ingeation } \\
\end{array}$}} & \multirow{2}{*}{\multicolumn{2}{|c|}{$\begin{array}{l}\text { Table II } \\
\text { Effluent }\end{array}$}} & \multirow{3}{*}{$\begin{array}{c}\text { Table III } \\
\text { Sewer } \\
\text { Discharge } \\
(\mu C I / m I)\end{array}$} \\
\hline & & & & & & & & & \\
\hline & \multicolumn{2}{|c|}{$C l a s s / E_{2}$} & $\begin{array}{c}\text { AInI } \\
(\mu \subset I)\end{array}$ & $\begin{array}{c}D A C \\
(\mu C 1 / \mathrm{ml}) \\
\end{array}$ & $\boldsymbol{f}_{2}$ & $\begin{array}{r}\text { ArI } \\
(\mu C 1)\end{array}$ & $\begin{array}{c}\text { Aix } \\
(\mu C 1 / \mathrm{ml})\end{array}$ & $\begin{array}{c}\text { Water } \\
(\mu C 1 / \operatorname{mi})\end{array}$ & \\
\hline \multicolumn{10}{|c|}{ Rhodium, cont'd. } \\
\hline $\begin{array}{l}\text { Rh-102 } \\
2.9 \mathrm{Y}\end{array}$ & $\begin{array}{l}D \\
Y\end{array}$ & $\begin{array}{l}0.05 \\
0.05 \\
0.05\end{array}$ & $\begin{array}{l}94 \\
160 \\
41\end{array}$ & $\begin{array}{l}3.9 E-08 \\
6.6 E-08 \\
1.7 E-08\end{array}$ & 0.05 & 470 & $5.7 E-11$ & $6.5 E-06$ & $6.5 E-05$ \\
\hline $\begin{array}{l}\text { Rh-102m } \\
207 d\end{array}$ & $\begin{array}{l}\vec{D} \\
\mathbf{Y}\end{array}$ & $\begin{array}{l}0.05 \\
0.05 \\
0.05\end{array}$ & $\begin{array}{l}500 \\
300 \\
100\end{array}$ & $\begin{array}{l}2.0 E-07 \\
1.2 E-07 \\
4.1 E-08\end{array}$ & 0.05 & 1000 & $1.45-10$ & $1.4 E-05$ & $1.4 E-04$ \\
\hline $\begin{array}{l}\mathrm{Rh}-103 \mathrm{~m} \\
56.12 \mathrm{~m}\end{array}$ & $\begin{array}{l}D \\
W \\
Y\end{array}$ & $\begin{array}{l}0.05 \\
0.05 \\
0.05\end{array}$ & $\begin{array}{l}9 \cdot 7 E+05 \\
1.1 E+06 \\
1.0 E+06\end{array}$ & $\begin{array}{l}4.0 E-04 \\
4.5 E-04 \\
4.1 E-04\end{array}$ & 0.05 & $4.3 E+05$ & $1.3 E-06$ & 0.0058 & 0.058 \\
\hline $\begin{array}{l}\mathrm{Rh}-105 \\
35.36 \mathrm{~h}\end{array}$ & $\begin{array}{l}\bar{D} \\
W \\
Y\end{array}$ & $\begin{array}{l}0.05 \\
0.05 \\
0.05\end{array}$ & $\begin{array}{l}1.05+04 \\
5700 \\
5200\end{array}$ & $\begin{array}{l}4.15-06 \\
2.35-06 \\
2.1 E-06\end{array}$ & 0.05 & 3300 & $7.25-09$ & $4.65-05$ & $4.6 E-04$ \\
\hline $\begin{array}{l}\mathrm{Rh}-106 \mathrm{~m} \\
132 \mathrm{~m}\end{array}$ & $\begin{array}{l}\mathbf{D} \\
\mathbf{W} \\
\mathbf{Y}\end{array}$ & $\begin{array}{l}0.05 \\
0.05 \\
0.05\end{array}$ & $\begin{array}{l}2 \cdot 3 E+04 \\
2.9 E+04 \\
2.7 E+04\end{array}$ & $\begin{array}{l}9.5 E-06 \\
1.2 E-05 \\
1.1 E-05\end{array}$ & 0.05 & 7700 & $3.25-08$ & 1. OE- 04 & $1.0 E-03$ \\
\hline $\begin{array}{l}\mathrm{Rh}-107 \\
21.7 \mathrm{~m}\end{array}$ & $\begin{array}{l}\mathbf{D} \\
\mathbf{W} \\
\mathbf{Y}\end{array}$ & $\begin{array}{l}0.05 \\
0.05 \\
0.05\end{array}$ & $\begin{array}{l}2.0 E+05 \\
2.4 E+05 \\
2.3 E+05\end{array}$ & $\begin{array}{l}8.3 E-05 \\
10 E-05 \\
9.5 E-05\end{array}$ & 0.05 & $\begin{array}{c}7.2 E+04 \\
(8.3 E+04) \\
\text { st wall }\end{array}$ & $2.8 E-07$ & 0.0011 & 0.011 \\
\hline \multicolumn{10}{|l|}{ PaIladium } \\
\hline $\begin{array}{l}P d-100 \\
3.63 d\end{array}$ & $\begin{array}{l}D \\
W \\
Y\end{array}$ & $\begin{array}{l}0.005 \\
0.005 \\
0.005\end{array}$ & $\begin{array}{l}1400 \\
1200 \\
1200\end{array}$ & $\begin{array}{l}5.8 E-07 \\
5.0 E-07 \\
5.0 E-07\end{array}$ & 0.005 & 1100 & $1.7 E-09$ & $1.5 E-05$ & $1.5 E-04$ \\
\hline $\begin{array}{l}P d-101 \\
8.27 \mathrm{~h}\end{array}$ & $\begin{array}{l}D \\
W \\
\mathbf{Y}\end{array}$ & $\begin{array}{l}0.005 \\
0.005 \\
0.005\end{array}$ & $\begin{array}{l}3 \cdot 1 E+04 \\
2 \cdot 9 E+04 \\
2 \cdot 6 E+04\end{array}$ & $\begin{array}{l}1.2 E-05 \\
1.2 E-05 \\
1.05-05\end{array}$ & 0.005 & $1 \cdot 2 E+04$ & $3.7 \mathbf{E}-08$ & 1. 6E-04 & $1.6 E-03$ \\
\hline $\begin{array}{l}\text { Pd-103 } \\
16.96 \mathrm{~d}\end{array}$ & $\begin{array}{l}\mathbf{D} \\
\mathbf{W} \\
\mathbf{Y}\end{array}$ & $\begin{array}{l}0.005 \\
0.005 \\
0.005\end{array}$ & $\begin{array}{l}5700 \\
3500 \\
3100\end{array}$ & $\begin{array}{l}2.3 E-06 \\
1.4 E-06 \\
1.2 E-06\end{array}$ & 0.005 & $\begin{array}{l}5800 \\
(6300) \\
\text { IfI wall }\end{array}$ & $4.4 E-09$ & $8.6 E-05$ & $8.6 E-04$ \\
\hline $\begin{array}{l}\text { Pd-107 } \\
6.5 E 6 \text { Y }\end{array}$ & $\begin{array}{l}\mathbf{D} \\
\mathbf{W} \\
\mathbf{Y}\end{array}$ & $\begin{array}{l}0.005 \\
0.005 \\
0.005\end{array}$ & $\begin{array}{l}1.95+04 \\
6100 \\
390\end{array}$ & $\begin{array}{l}7.95-06 \\
2.5 E-06 \\
1.65-07\end{array}$ & 0.005 & $\begin{array}{r}2.8 E+04 \\
(3.3 E+04) \\
\text { LII waIl }\end{array}$ & $5.4 E-10$ & $4.5 E-04$ & $4.5 E-03$ \\
\hline $\begin{array}{l}\text { Pd-109 } \\
13.427 \mathrm{~h}\end{array}$ & $\begin{array}{l}\mathbf{D} \\
\mathbf{W} \\
\mathbf{Y}\end{array}$ & $\begin{array}{l}0.005 \\
0.005 \\
0.005\end{array}$ & $\begin{array}{l}6000 \\
4900 \\
4500\end{array}$ & $\begin{array}{l}2.5 E-06 \\
2.0 E-06 \\
1.8 E-06\end{array}$ & 0.005 & 2300 & $6.35-09$ & $3.15-05$ & $3.1 E-04$ \\
\hline \multicolumn{10}{|l|}{ Silver } \\
\hline $\begin{array}{l}\mathrm{Ag}-102 \\
12.9 \mathrm{~m}\end{array}$ & $\begin{array}{l}D \\
W \\
Y\end{array}$ & $\begin{array}{l}0.05 \\
0.05 \\
0.05\end{array}$ & $\begin{array}{l}1.4 E+05 \\
1.7 E+05 \\
1.7 E+05\end{array}$ & $\begin{array}{l}5.8 E-05 \\
7.0 E-05 \\
7.0 E-05\end{array}$ & 0.05 & $\begin{array}{c}4.5 E+04 \\
(4.9 E+04) \\
\text { st wall }\end{array}$ & $2.05-07$ & $6.7 \mathrm{E}-04$ & $6.7 E-03$ \\
\hline $\begin{array}{l}\mathrm{Ag}-103 \\
65.7 \mathrm{~m}\end{array}$ & $\begin{array}{l}\mathbf{D} \\
\mathbf{Y} \\
\mathbf{Y}\end{array}$ & $\begin{array}{l}0.05 \\
0.05 \\
0.05\end{array}$ & $\begin{array}{l}8.5 E+04 \\
1.0 E+05 \\
9.75+04\end{array}$ & $\begin{array}{l}3.5 E-05 \\
4.15-05 \\
4.05-05\end{array}$ & 0.05 & $3.3 \mathrm{E}+04$ & $1.2 E-07$ & $4.6 E-04$ & $4.6 E-03$ \\
\hline $\begin{array}{l}\mathrm{Ag}-104 \\
69.2 \mathrm{~m}\end{array}$ & $\begin{array}{l}D \\
W \\
Y\end{array}$ & $\begin{array}{l}0.05 \\
0.05 \\
0.05\end{array}$ & $\begin{array}{l}\text { 7. } 05+04 \\
1.05+05 \\
9.95+04\end{array}$ & $\begin{array}{l}2.9 E-05 \\
4.1 E-05 \\
4.1 E-05\end{array}$ & 0.05 & $2.1 E+04$ & $9.7 \mathrm{E}-08$ & $2.9 E-04$ & $2.9 E-03$ \\
\hline $\begin{array}{l}\mathrm{Ag}-104 \mathrm{~m} \\
33.5 \mathrm{~m}\end{array}$ & $\begin{array}{l}\mathbf{D} \\
\mathbf{W} \\
\mathbf{Y}\end{array}$ & $\begin{array}{l}0.05 \\
0.05 \\
0.05\end{array}$ & $\begin{array}{l}7.95+04 \\
1.05+05 \\
9.7 E+04\end{array}$ & $\begin{array}{l}3.2 E-05 \\
4.1 E-05 \\
4.0 E-05\end{array}$ & 0.05 & $2.95+04$ & $1.1 \Sigma-07$ & $4.05-04$ & $4.0 E-03$ \\
\hline $\begin{array}{l}\mathrm{Ag}-105 \\
41.0 \mathrm{~d}\end{array}$ & $\begin{array}{l}D \\
Y \\
Y\end{array}$ & $\begin{array}{l}0.05 \\
0.05 \\
0.05\end{array}$ & $\begin{array}{l}1000 \\
1300 \\
1100\end{array}$ & $\begin{array}{l}4.1 E-07 \\
5.4 E-07 \\
4.5 E-07\end{array}$ & 0.05 & 2400 & $1.4 E-09$ & $3.3 E-05$ & $3.3 E-04$ \\
\hline $\begin{array}{l}\mathrm{Ag}-106 \\
23.96 \mathrm{~m}\end{array}$ & $\begin{array}{l}\mathbf{D} \\
\mathbf{W} \\
\mathbf{Y}\end{array}$ & $\begin{array}{l}0.05 \\
0.05 \\
0.05\end{array}$ & $\begin{array}{l}1.5 E+05 \\
1.85+05 \\
1.75+05\end{array}$ & $\begin{array}{l}6.25-05 \\
7.5 E-05 \\
7.0 E-05\end{array}$ & 0.05 & $\begin{array}{c}5.5 E+04 \\
(5.9 E+04) \\
\text { st wall }\end{array}$ & $2.1 E-07$ & $8.1 E-04$ & 8.1E-03 \\
\hline $\begin{array}{l}\mathrm{Ag}-106 \mathrm{~m} \\
8.41 \mathrm{~d}\end{array}$ & $\begin{array}{l}D \\
W \\
Y\end{array}$ & $\begin{array}{l}0.05 \\
0.05 \\
0.05\end{array}$ & $\begin{array}{l}690 \\
870 \\
900\end{array}$ & $\begin{array}{l}2.85-07 \\
3.65-07 \\
3.75-07\end{array}$ & 0.05 & 770 & $9.75-10$ & $1.0 \mathrm{E}-05$ & 1. $0 E-04$ \\
\hline $\begin{array}{l}\mathrm{Ag}-108 \mathrm{~m} \\
127 Y\end{array}$ & $\begin{array}{l}D \\
W \\
Y\end{array}$ & $\begin{array}{l}0.05 \\
0.05 \\
0.05\end{array}$ & $\begin{array}{l}160 \\
190 \\
17\end{array}$ & $\begin{array}{l}6.6 E-08 \\
7.9 E-08 \\
7.0 E-09\end{array}$ & 0.05 & 650 & $2.4 E-11$ & 8. $9 E-06$ & $8.9 E-05$ \\
\hline $\begin{array}{l}\mathrm{Ag}-110 \mathrm{~m} \\
249.9 d\end{array}$ & $\begin{array}{l}D \\
W \\
Y\end{array}$ & $\begin{array}{l}0.05 \\
0.05 \\
0.05\end{array}$ & $\begin{array}{l}120 \\
160 \\
62\end{array}$ & $\begin{array}{l}5.0 E-08 \\
6.6 E-08 \\
2.5 E-08\end{array}$ & 0.05 & 460 & $8.6 E-11$ & $6.3 E-06$ & $6.3 E-05$ \\
\hline $\begin{array}{l}\mathrm{Ag}-111 \\
7.45 \mathrm{~d}\end{array}$ & $\begin{array}{l}D \\
W \\
Y\end{array}$ & $\begin{array}{l}0.05 \\
0.05 \\
0.05\end{array}$ & $\begin{array}{l}1400 \\
860 \\
810\end{array}$ & $\begin{array}{l}5.8 E-07 \\
3.5 E-07 \\
3.35-07\end{array}$ & 0.05 & $\begin{array}{l}910 \\
(980) \\
\text { III wall }\end{array}$ & $1.1 E-09$ & $1.3 E-05$ & I. $3 E-04$ \\
\hline $\begin{array}{l}\mathrm{Ag}-112 \\
3.12 \mathrm{~h}\end{array}$ & $\begin{array}{l}D \\
\mathbf{W} \\
\mathbf{Y}\end{array}$ & $\begin{array}{l}0.05 \\
0.05 \\
0.05\end{array}$ & $\begin{array}{l}7600 \\
8200 \\
7500\end{array}$ & $\begin{array}{l}3.1 E-05 \\
3.4 E-06 \\
3.1 E-06\end{array}$ & 0.05 & 3000 & $1.0 E-08$ & 4.IE-05 & $4.15-04$ \\
\hline $\begin{array}{l}\mathrm{Ag}-115 \\
20.0 \mathrm{~m}\end{array}$ & $\begin{array}{l}\bar{D} \\
W \\
Y\end{array}$ & $\begin{array}{l}0.05 \\
0.05 \\
0.05\end{array}$ & $\begin{array}{l}7.6 E+04 \\
7.5 E+04 \\
7.1 E+04\end{array}$ & $\begin{array}{l}3.1 E-05 \\
3.1 E-05 \\
2.9 E-05\end{array}$ & 0.05 & $3 \cdot 15+04$ & $9.8 E-08$ & $4.2 E-04$ & $4.2 E-03$ \\
\hline
\end{tabular}




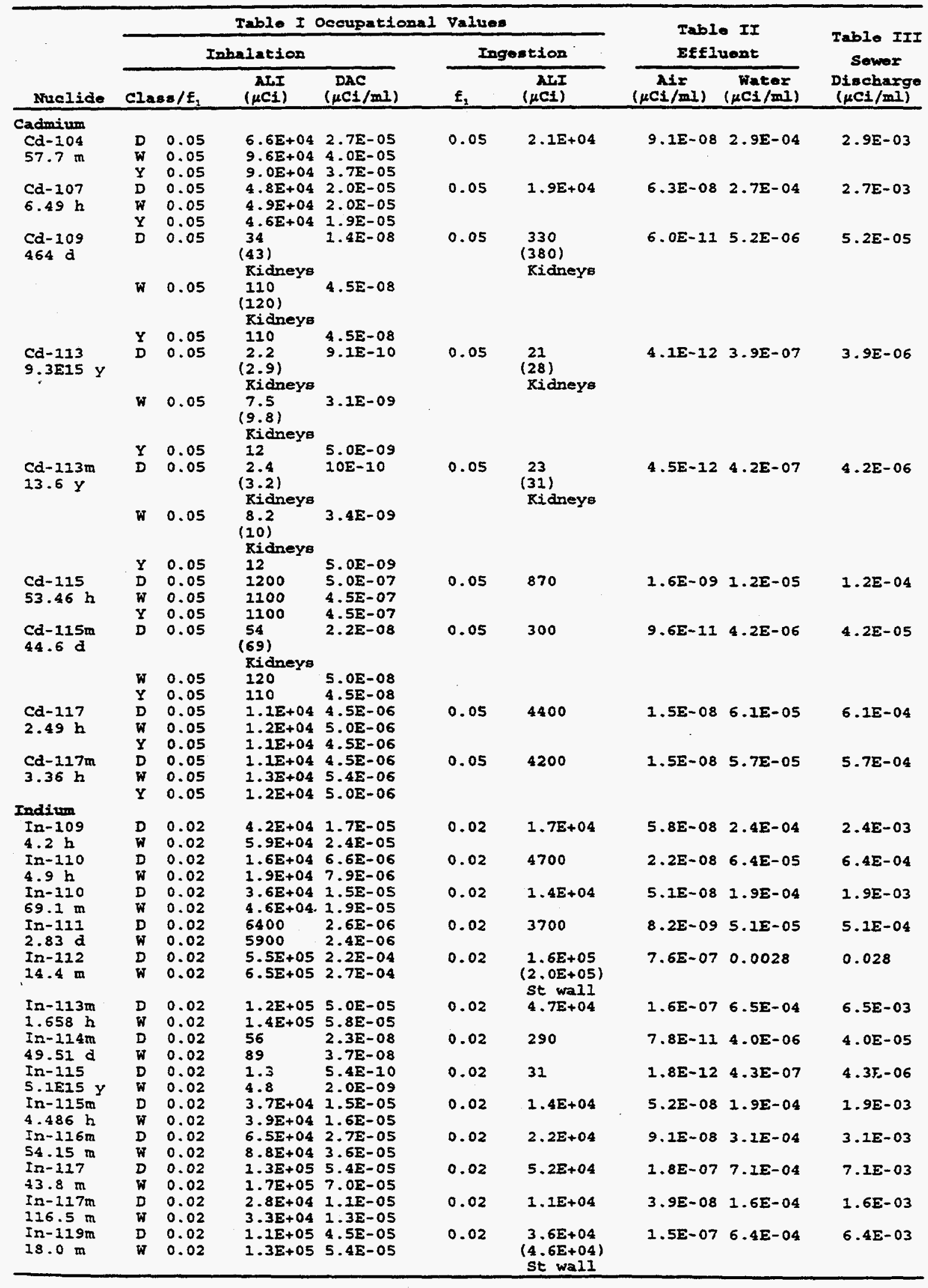




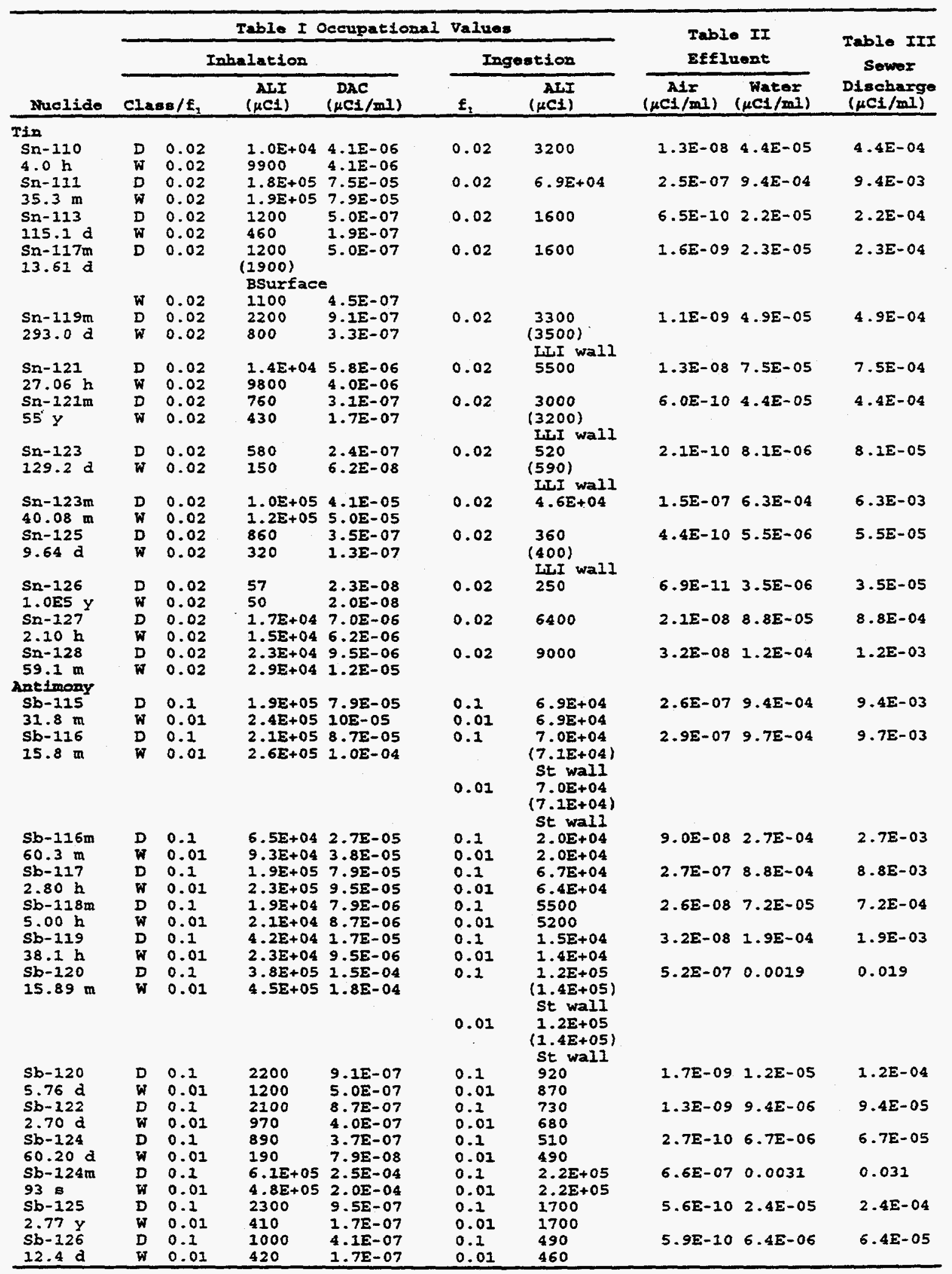




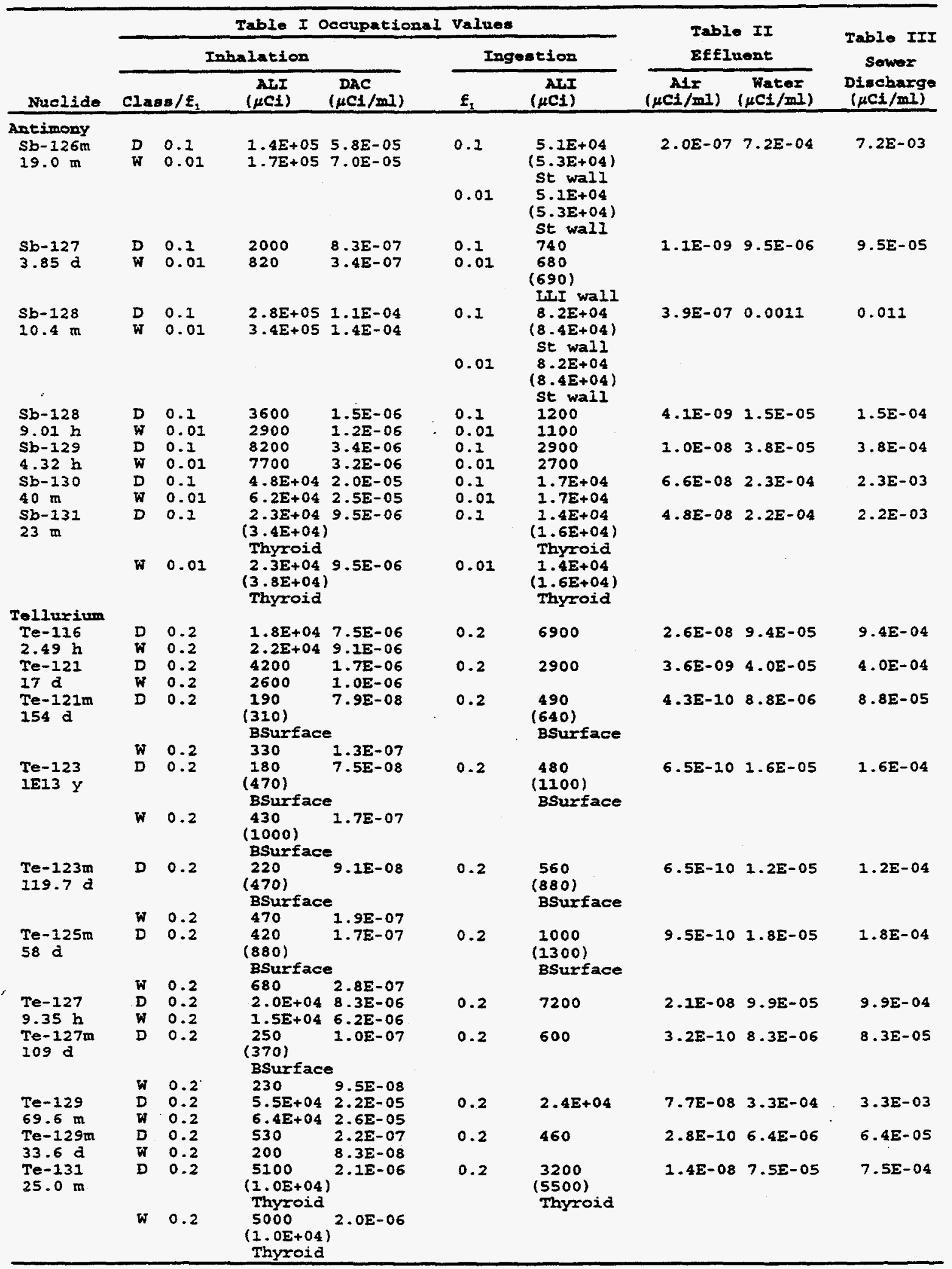




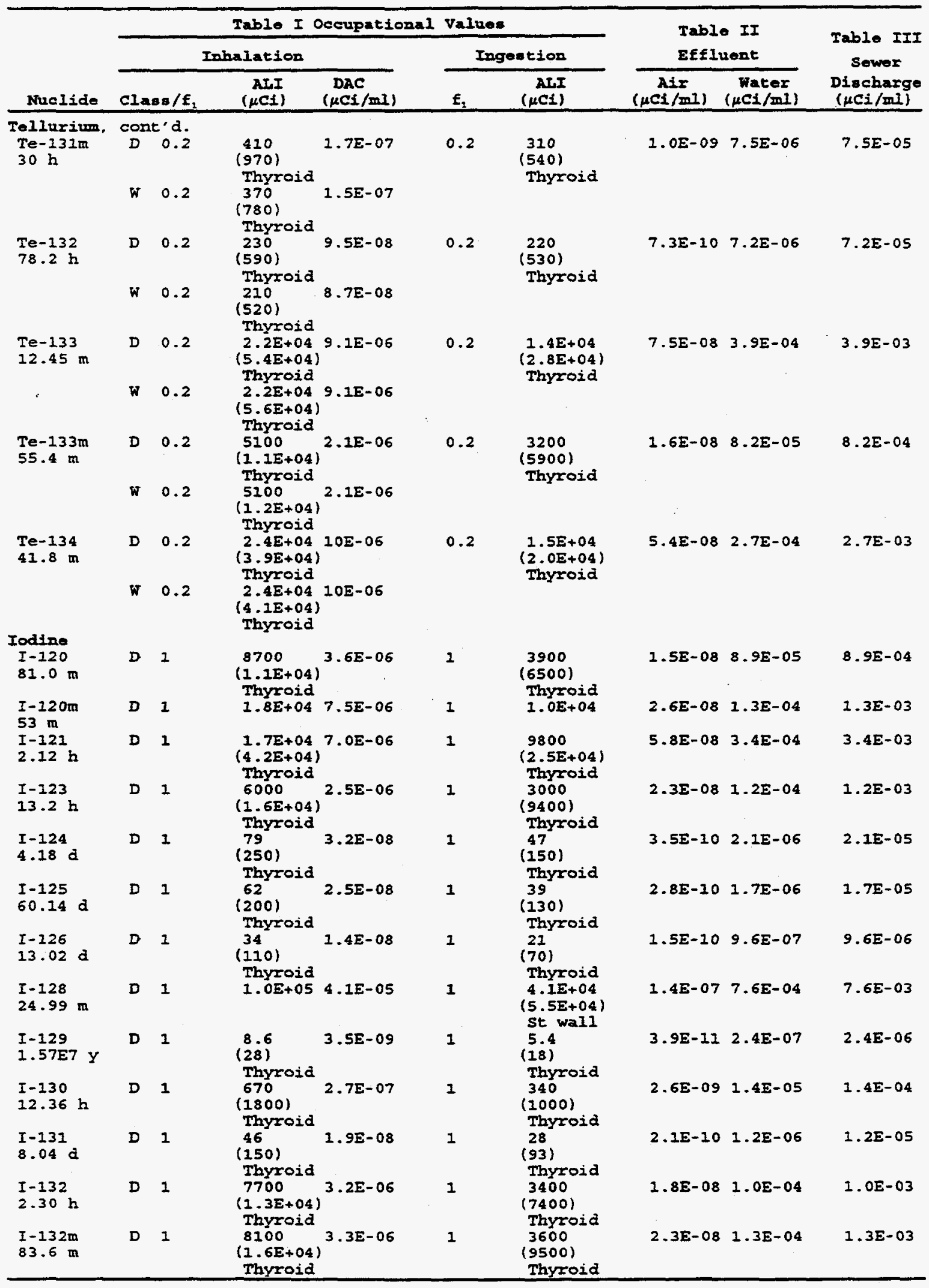




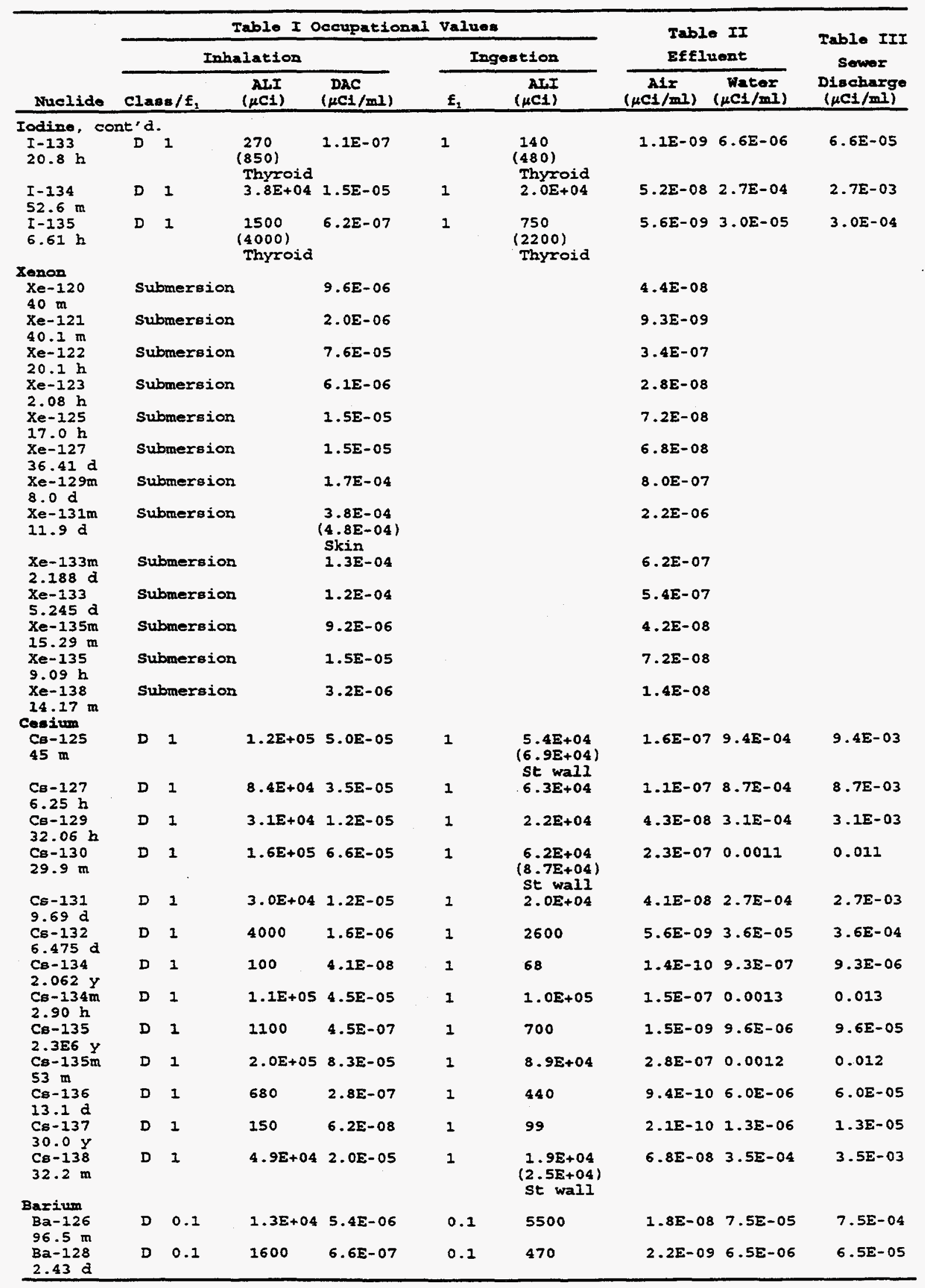




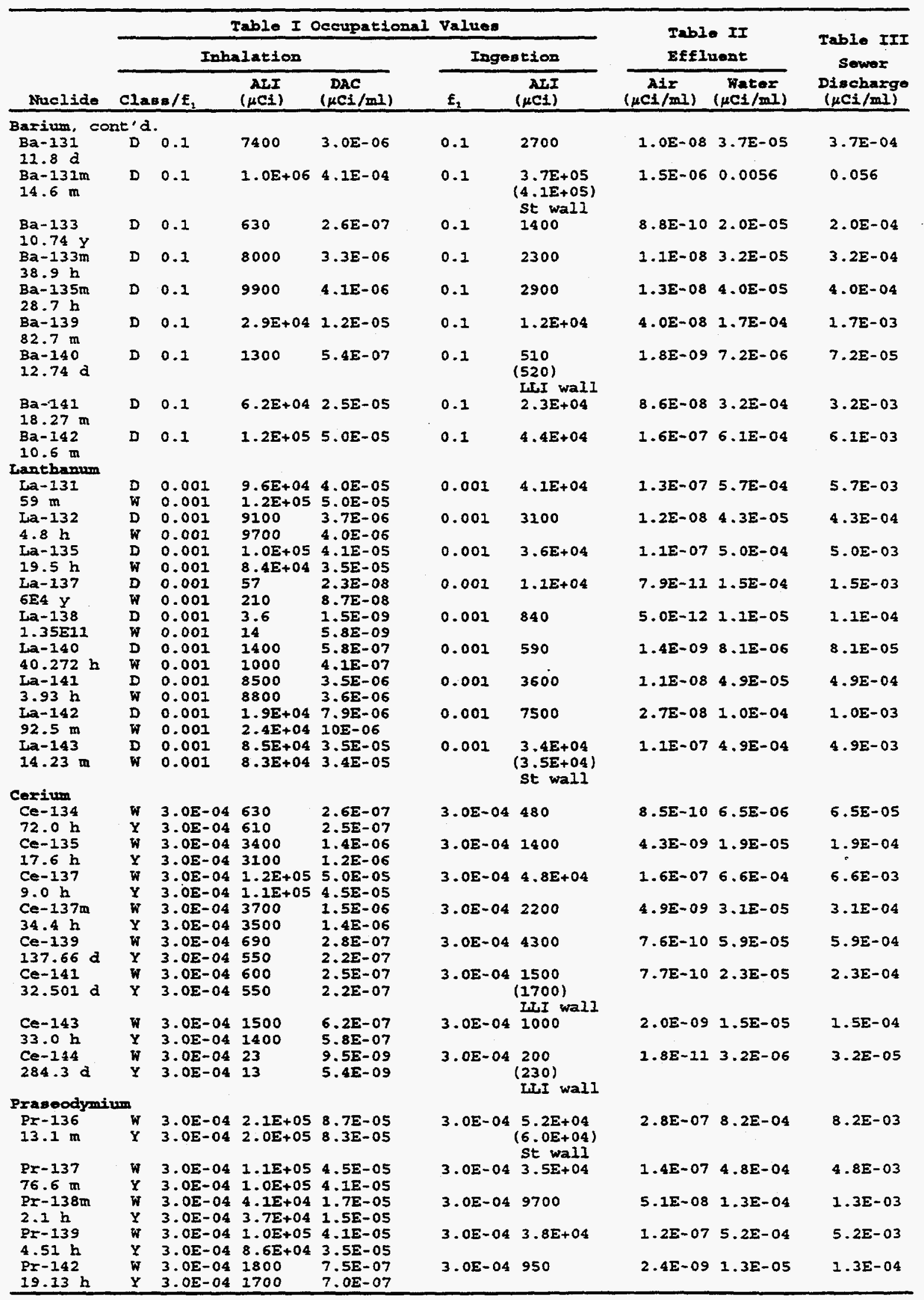




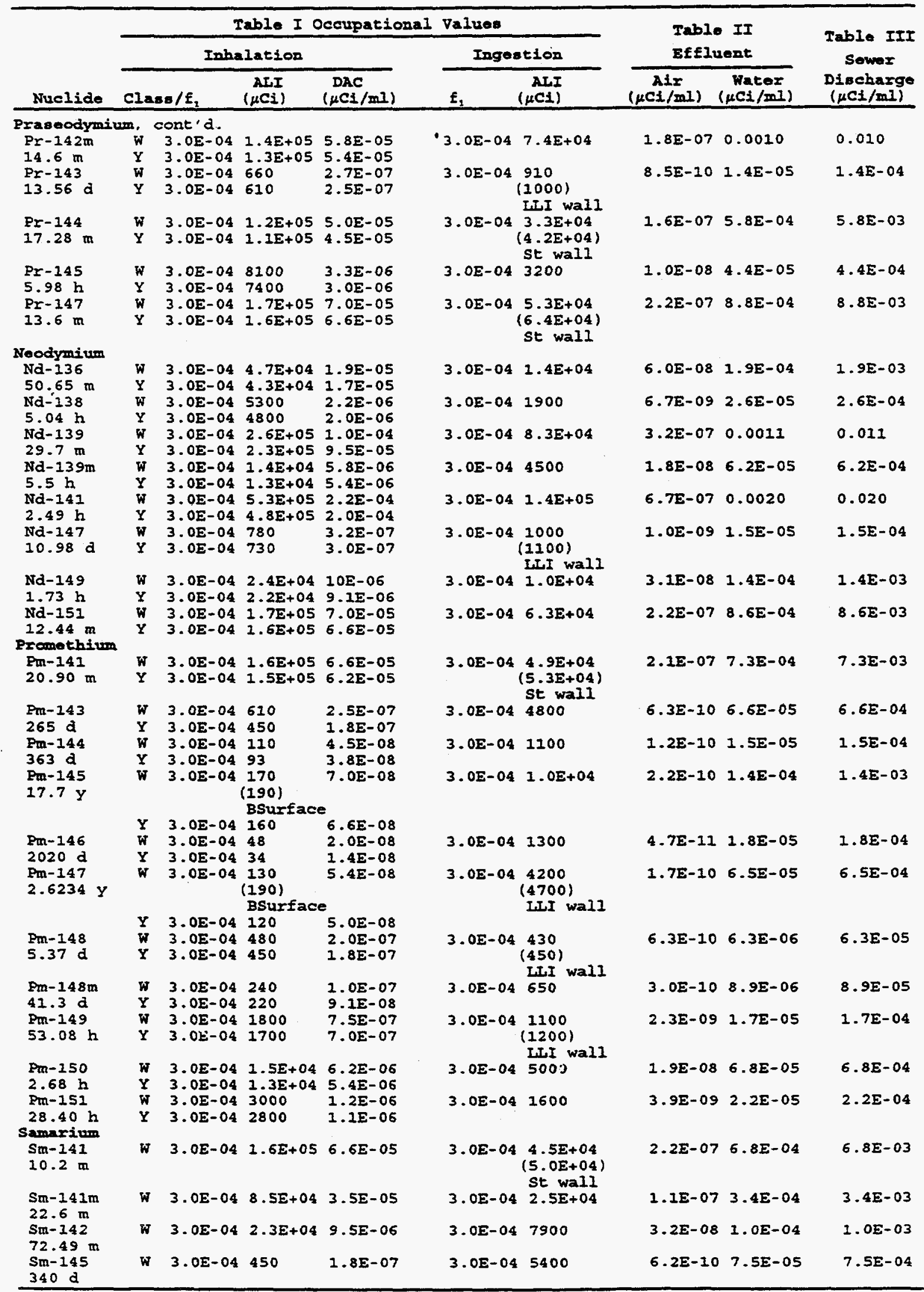




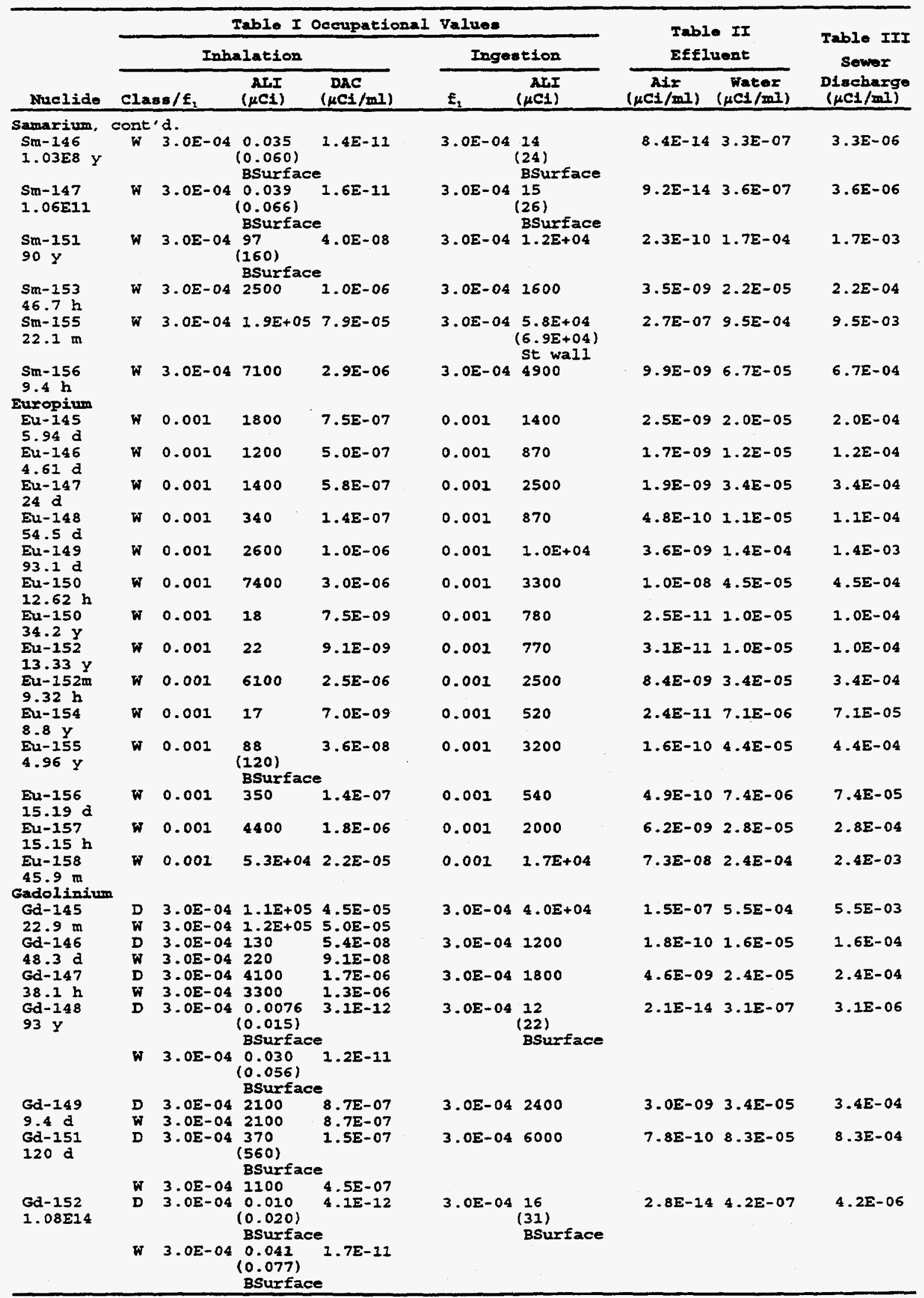




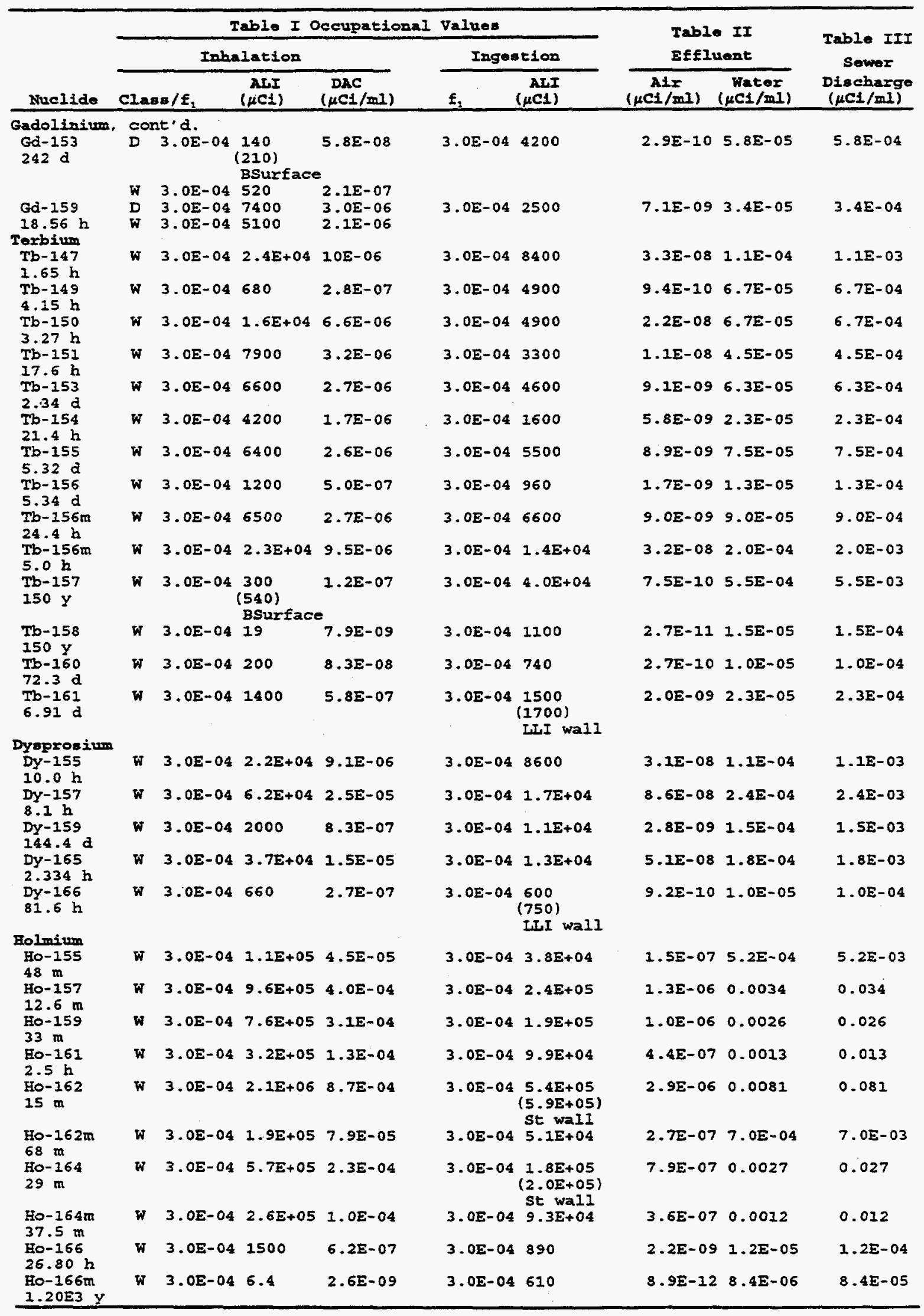




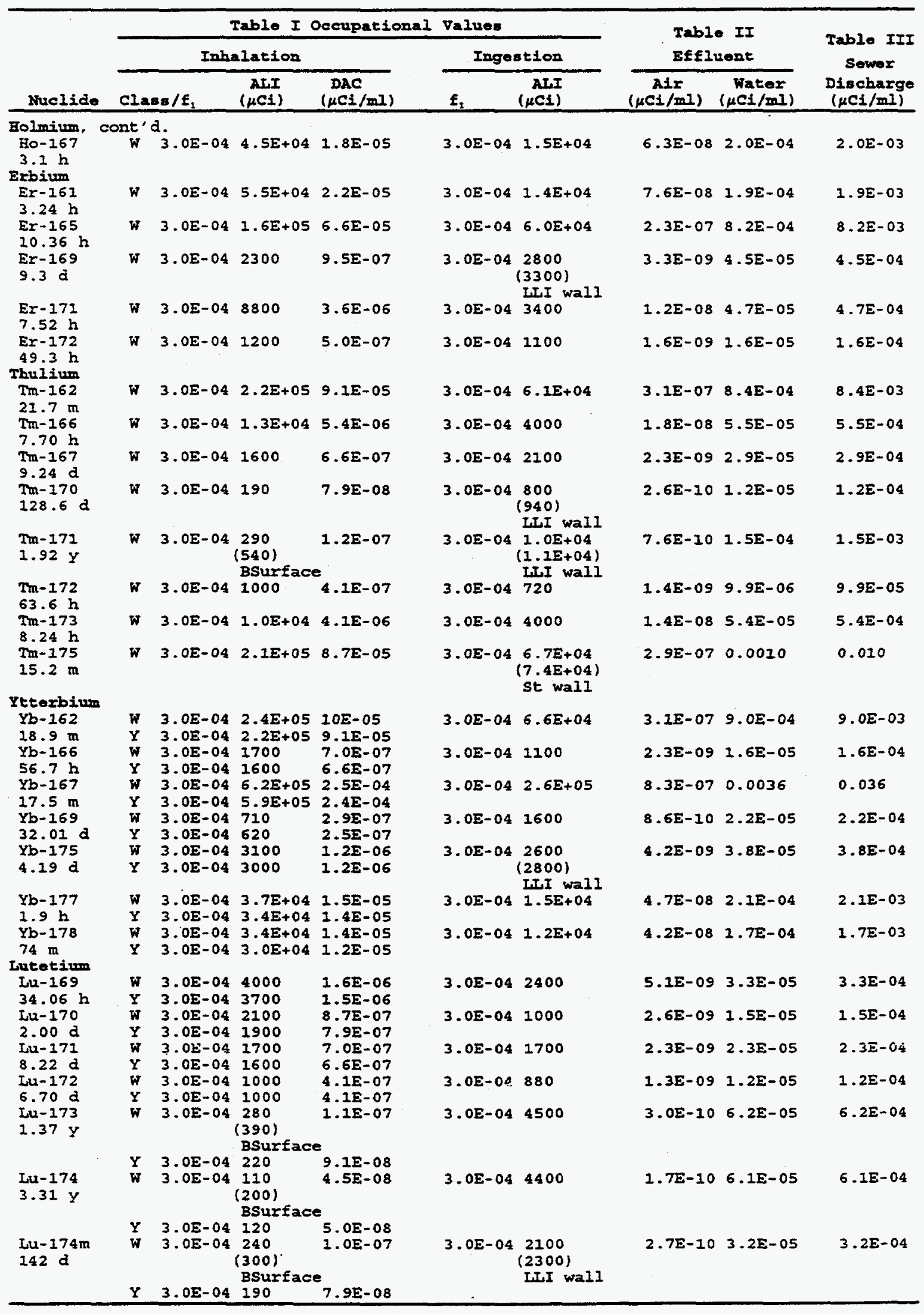




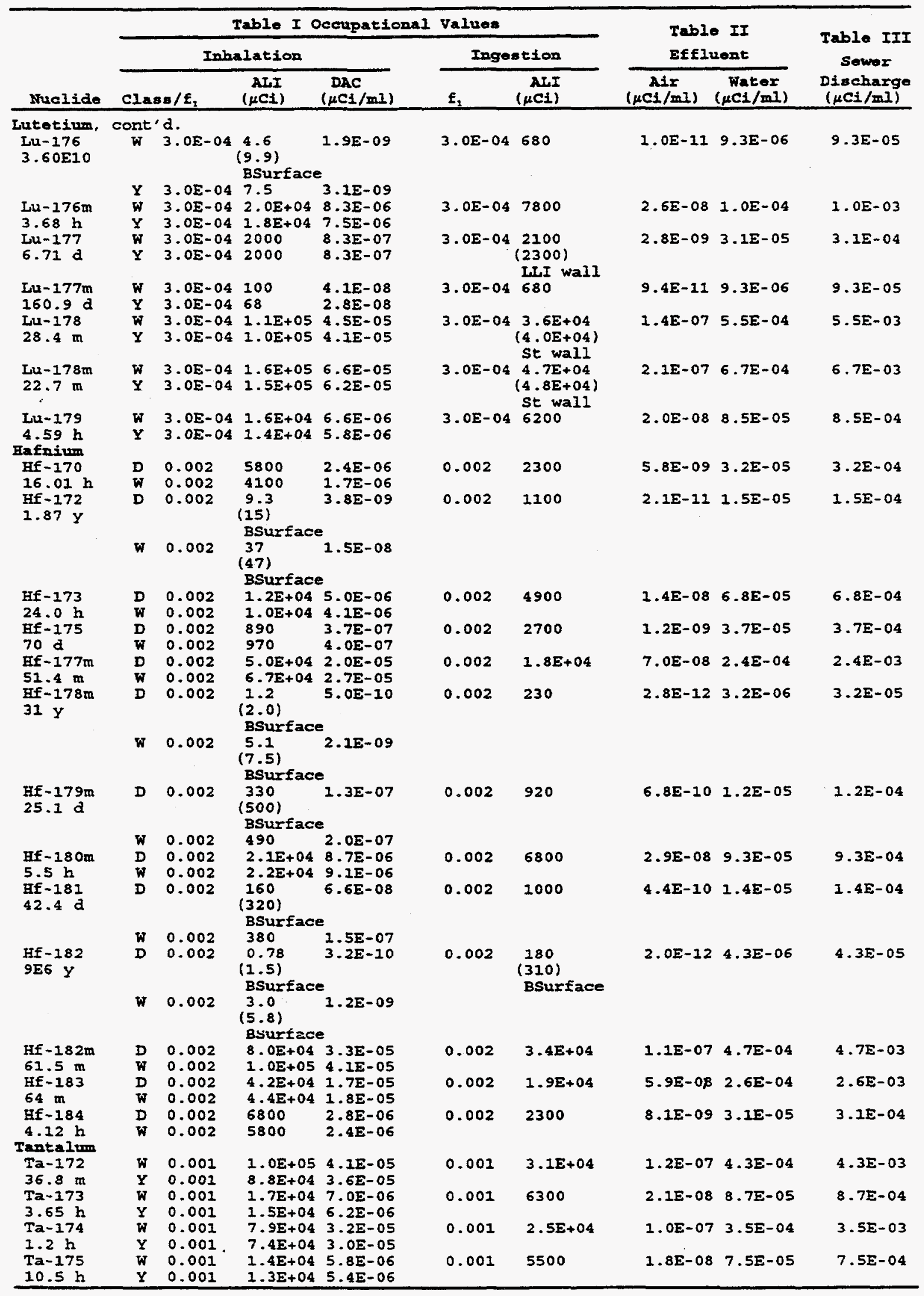




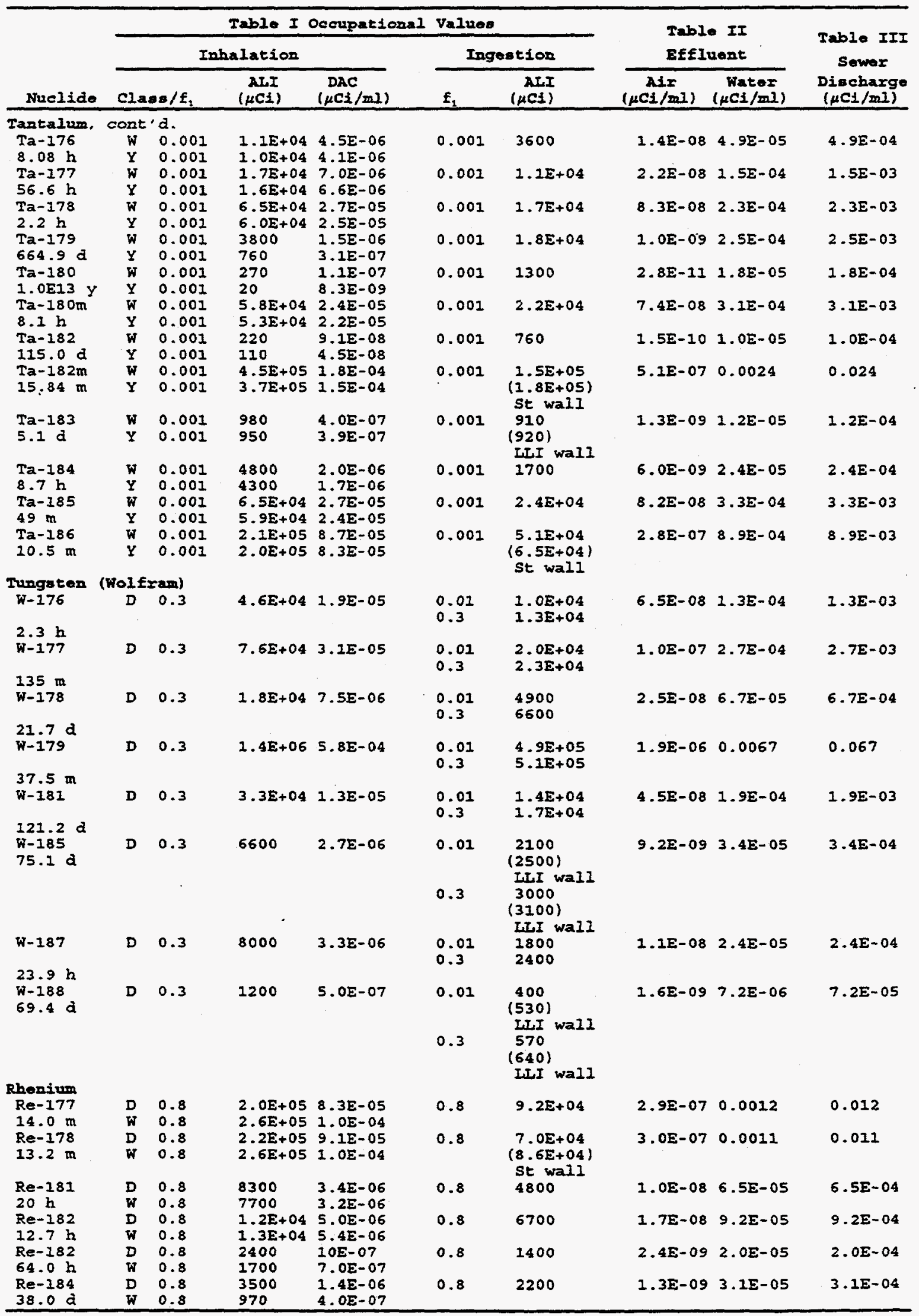




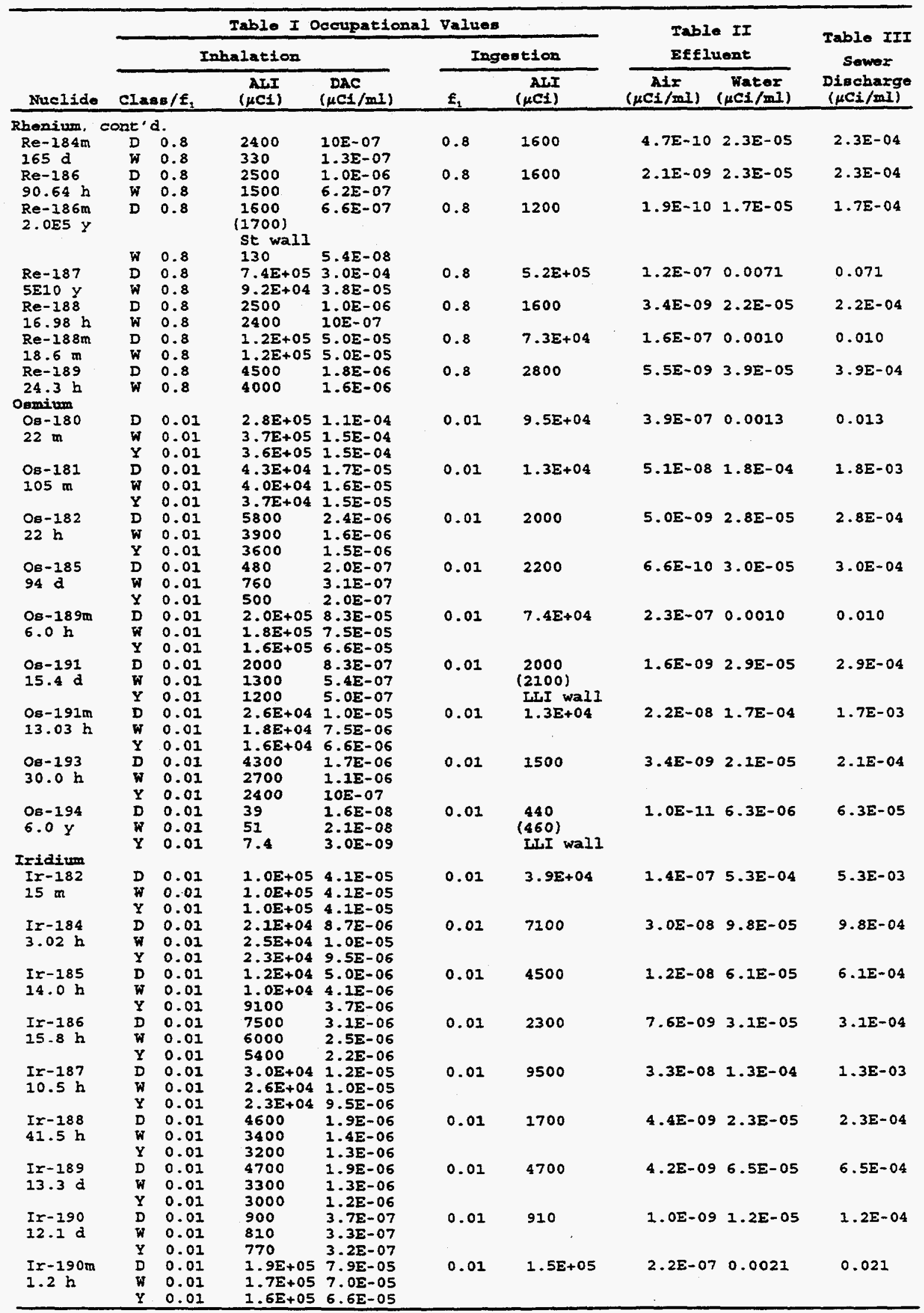




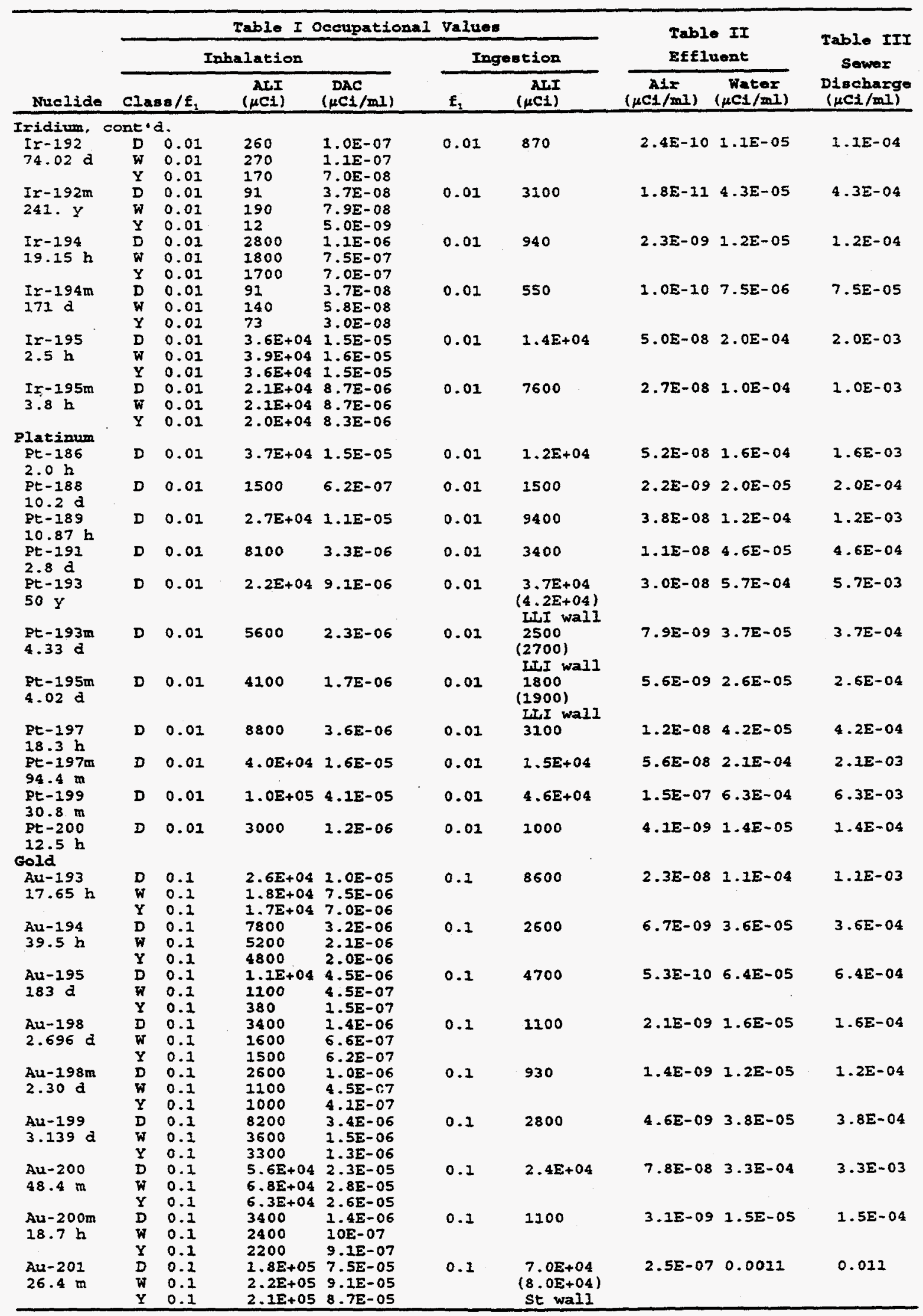




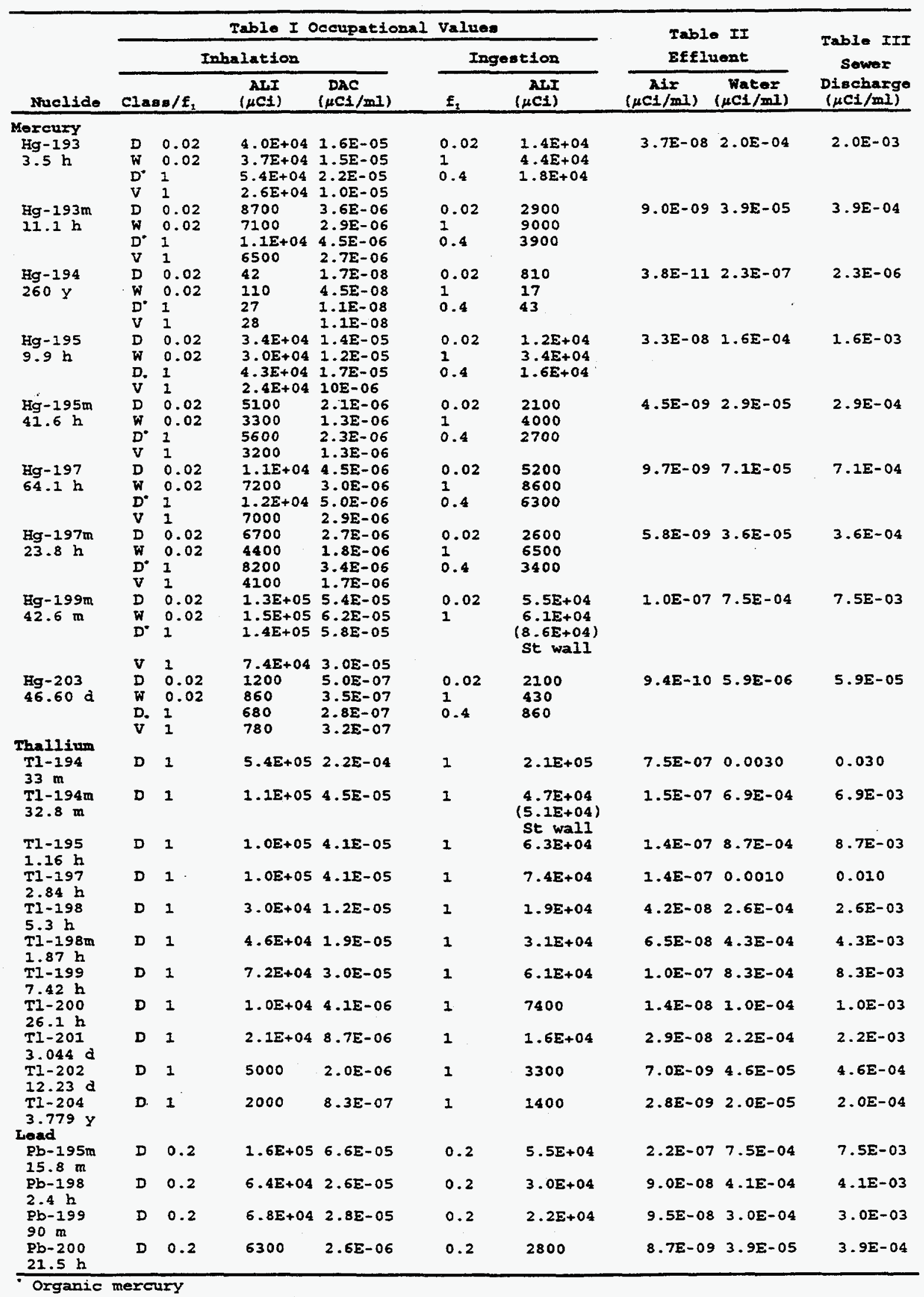




\begin{tabular}{|c|c|c|c|c|c|c|c|c|c|}
\hline \multirow[b]{3}{*}{ Muclide } & \multicolumn{6}{|c|}{ Table I Occupational Values } & \multirow{2}{*}{\multicolumn{2}{|c|}{$\begin{array}{l}\text { Table II } \\
\text { EfEluent }\end{array}$}} & \multirow{3}{*}{$\begin{array}{c}\text { Table III } \\
\text { Sewer } \\
\text { Discharge } \\
(\mu \mathrm{C} i / \mathrm{ml})\end{array}$} \\
\hline & \multicolumn{4}{|c|}{ Inbalation } & \multicolumn{2}{|c|}{ Ingestion } & & & \\
\hline & \multicolumn{2}{|c|}{ Class/f } & \multirow{3}{*}{$\begin{array}{c}\begin{array}{c}\text { ALI } \\
\text { (HCI) }\end{array} \\
1.9 E+04\end{array}$} & \multirow{3}{*}{$\begin{array}{c}\begin{array}{c}\mathrm{DAC} \\
(\mu \mathrm{Ci} / \mathrm{ml})\end{array} \\
7.9 \mathrm{E}-06\end{array}$} & \multirow{3}{*}{$\frac{E_{2}}{0.2}$} & \multirow{2}{*}{$\begin{array}{r}\text { AXI } \\
(\mu C I) \\
\end{array}$} & \multirow{3}{*}{$\frac{\begin{array}{c}A i x \\
(\mu \mathrm{Ci} / \mathrm{ml})\end{array}}{2.6 \mathrm{E}-08}$} & $\begin{array}{c}\text { Water } \\
(\mu \mathrm{Ci} / \mathrm{mI})\end{array}$ & \\
\hline Lead, cont & & & & & & & & & \\
\hline $\begin{array}{l}\mathrm{Pb}-201 \\
9.4 \mathrm{~h}\end{array}$ & D & 0.2 & & & & 7000 & & $9.6 E-05$ & $9.6 E-04$ \\
\hline $\begin{array}{l}\mathrm{Pb}-202 \\
3 E 5 \mathrm{Y}\end{array}$ & D & 0.2 & 50 & $2.0 E-08$ & 0.2 & 120 & 7. OE- 11 & $1.7 E-06$ & $1.7 E-05$ \\
\hline $\begin{array}{l}\mathrm{Pb}-202 \mathrm{~m} \\
3.62 \mathrm{~h}\end{array}$ & D & 0.2 & $2.7 E+04$ & 2.2E-05 & 0.2 & 8800 & $3.8 \mathrm{E}-08$ & $1.2 E-04$ & $1.2 E-03$ \\
\hline $\begin{array}{l}\mathrm{Pb}-203 \\
52.05 \mathrm{~h}\end{array}$ & $D$ & 0.2 & 9400 & $3.9 E-06$ & 0.2 & 4600 & $1.3 E-08$ & $6.3 E-05$ & $6.3 E-04$ \\
\hline $\begin{array}{l}\mathrm{Pb}-205 \\
1.4327 \mathrm{Y}\end{array}$ & $\mathbf{D}$ & 0.2 & 1200 & 5.0E-07 & 0.2 & 3000 & $1.7 E-09$ & $4.2 E-05$ & 4. $1 E-04$ \\
\hline $\begin{array}{l}\mathrm{Pb}-209 \\
3.253 \mathrm{~b}\end{array}$ & $\mathrm{D}$ & 0.2 & $5.2 E+04$ & $2.1 E-05$ & 0.2 & $2.3 E+04$ & $7.3 E-08$ & $3.2 E-04$ & $3.2 E-03$ \\
\hline $\begin{array}{l}\mathrm{Pb}-210 \\
22.3 \mathrm{y}\end{array}$ & $\mathrm{D}$ & 0.2 & $\begin{array}{l}0.24 \\
(0.36) \\
\text { Bsurface }\end{array}$ & $\begin{array}{l}1.0 E-10 \\
\end{array}$ & 0.2 & $\begin{array}{l}0.62 \\
(0.93) \\
\text { BSurface }\end{array}$ & 5.IE-13 & $1.2 E-08$ & $1.2 E-07$ \\
\hline $\begin{array}{l}\mathrm{Pb}-211 \\
36.1 \mathrm{~m}\end{array}$ & D & 0.2 & 570 & $2.3 E-07$ & 0.2 & 9500 & $7.9 E-10$ & $1.3 E-04$ & $1.3 E-03$ \\
\hline $\begin{array}{l}P b-212 \\
10.64 \text { h }\end{array}$ & D & 0.2 & 29 & 1. $2 E-08$ & 0.2 & $\begin{array}{l}81 \\
(100) \\
\text { BSurface }\end{array}$ & $4.1 E-11$ & $1.5 E-06$ & $1.5 E-05$ \\
\hline $\begin{array}{r}\mathrm{Pb}-214 \\
26.8 \mathrm{~m} \\
\text { Bismuth }\end{array}$ & D & 0.2 & 640 & $2.6 E-07$ & 0.2 & 7900 & $8.9 E-10$ & 1.OE-04 & $1.05-03$ \\
\hline $\begin{array}{l}3 i-200 \\
36.4 \mathrm{~m}\end{array}$ & $\underset{W}{D}$ & $\begin{array}{l}0.05 \\
0.05\end{array}$ & $\begin{array}{l}7 \cdot 5 E+04 \\
8 \cdot 3 E+04\end{array}$ & $\begin{array}{l}3.1 E-05 \\
3.4 E-05\end{array}$ & 0.05 & $2.7 E+04$ & $1.0 E-07$ & $3.7 E-04$ & $3.7 E-03$ \\
\hline $\begin{array}{l}\mathrm{Bi}-201 \\
108 \mathrm{~m}\end{array}$ & $\mathbf{D}$ & $\begin{array}{l}0.05 \\
0.05\end{array}$ & $\begin{array}{l}2 \cdot 6 E+04 \\
3.1 E+04\end{array}$ & $\begin{array}{l}1.0 E-05 \\
1.2 E-05\end{array}$ & 0.05 & $1.05+04$ & $3.6 E-08$ & $2.4 E-04$ & $1.4 E-03$ \\
\hline $\begin{array}{l}8 i-202 \\
1.67 \mathrm{~h}\end{array}$ & $\begin{array}{l}\mathbf{D} \\
\mathbf{W}\end{array}$ & $\begin{array}{l}0.05 \\
0.05\end{array}$ & $\begin{array}{l}3.9 E+04 \\
6.1 E+04\end{array}$ & $\begin{array}{l}1.6 E-05 \\
2.5 E-05\end{array}$ & 0.05 & $1 \cdot 3 E+04$ & $5.4 E-08$ & $1.92-04$ & $1.9 E-03$ \\
\hline $\begin{array}{l}\mathrm{Bi}-203 \\
11.76 \mathrm{~h}\end{array}$ & $D$ & $\begin{array}{l}0.05 \\
0.05\end{array}$ & $\begin{array}{l}6600 \\
5000\end{array}$ & $\begin{array}{l}2.7 E-06 \\
2.5 E-06\end{array}$ & 0.05 & 2300 & $8.3 E-09$ & 3.1E-05 & $3.1 E-04$ \\
\hline $\begin{array}{l}B i-205 \\
15.31 d\end{array}$ & D & $\begin{array}{l}0.05 \\
0.05\end{array}$ & $\begin{array}{l}2400 \\
1100\end{array}$ & $\begin{array}{l}10 E-07 \\
4.5 E-07\end{array}$ & 0.05 & 1200 & $1.6 \mathrm{E}-09$ & $1.7 E-05$ & I. $7 E-04$ \\
\hline $\begin{array}{l}B i-206 \\
6.243 \\
B i-207\end{array}$ & $\begin{array}{l}D \\
D \\
D\end{array}$ & $\begin{array}{l}0.05 \\
0.05 \\
0.05\end{array}$ & $\begin{array}{l}1300 \\
760 \\
1500\end{array}$ & $\begin{array}{l}5.4 E-07 \\
3.1 E-07 \\
6.2 E-07\end{array}$ & $\begin{array}{l}0.05 \\
0.05\end{array}$ & 590 & $\begin{array}{l}1.05-09 \\
3.4 E-10\end{array}$ & $\begin{array}{l}\text { 8.1E-06 } \\
1.2 E-05\end{array}$ & $\begin{array}{l}8.1 E-05 \\
1.25-04\end{array}$ \\
\hline $\begin{array}{l}38 y \\
3 i-210 \\
5.012 d\end{array}$ & $\underset{D}{W}$ & $\begin{array}{l}0.05 \\
0.05\end{array}$ & $\begin{array}{l}240 \\
230 \\
(320) \\
\text { Kidneys } \\
25\end{array}$ & $\begin{array}{l}1.0 E-07 \\
9.5 E-08 \\
1.0 E-08\end{array}$ & 0.05 & 780 & $3.5 \mathrm{E}-11$ & 1.0 E-05 & 1. 0 E-04 \\
\hline $\begin{array}{l}\text { Bi-210m } \\
3.056 \text { y }\end{array}$ & $\ddot{D}$ & 0.05 & $\begin{array}{l}4.5 \\
(5.0) \\
\text { Ridneys }\end{array}$ & $\begin{array}{l}1.0 E-08 \\
1.8 E-09\end{array}$ & 0.05 & $\begin{array}{l}44 \\
(52) \\
\text { Kidneys }\end{array}$ & $9.15-13$ & $7.1 E-07$ & $7.1 E-06$ \\
\hline $\begin{array}{l}\mathrm{Bi}-212 \\
60.55 \mathrm{~m}\end{array}$ & $\begin{array}{l}W \\
D \\
W\end{array}$ & $\begin{array}{l}0.05 \\
0.05 \\
0.05\end{array}$ & $\begin{array}{l}0.65 \\
230 \\
260\end{array}$ & $\begin{array}{l}2.7 E-10 \\
9.5 E-08 \\
1.0 E-07\end{array}$ & 0.05 & 4700 & $3.2 E-10$ & $6.4 E-05$ & $6.4 E-04$ \\
\hline $\begin{array}{l}\mathrm{Bi}-213 \\
45.65 \mathrm{~m}\end{array}$ & $\vec{D}$ & $\begin{array}{l}0.05 \\
0.05\end{array}$ & $\begin{array}{l}290 \\
320\end{array}$ & $\begin{array}{l}1.2 E-07 \\
1.3 E-07\end{array}$ & 0.05 & 6900 & 4. OE-10 & $9.4 E-05$ & $9.4 E-04$ \\
\hline $\begin{array}{l}3 i-214 \\
19.9 \mathrm{~m}\end{array}$ & $\begin{array}{l}D \\
W\end{array}$ & $\begin{array}{l}0.05 \\
0.05\end{array}$ & $\begin{array}{l}760 \\
800\end{array}$ & $\begin{array}{l}3.1 E-07 \\
3.3 E-07\end{array}$ & 0.05 & $\begin{array}{c}1.5 E+04 \\
(1.7 E+04) \\
\text { st wall }\end{array}$ & 1.0E-09 & $2.4 E-04$ & $2.4 E-03$ \\
\hline Polonium & & & & & & & & & \\
\hline $\begin{array}{l}\mathrm{Po}-203 \\
36.7 \mathrm{~m}\end{array}$ & 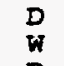 & 0.1 & $\begin{array}{l}6 \cdot 3 E+04 \\
6.7 E+04\end{array}$ & $\begin{array}{l}2.6 \Sigma-05 \\
2.7 E-05\end{array}$ & 0.1 & $2.4 E+04$ & $8.7 E-08$ & $3.4 E-04$ & $3.4 E-03$ \\
\hline $\begin{array}{l}\text { P0-205 } \\
1.80 \mathrm{~h}\end{array}$ & D & $\begin{array}{l}0.1 \\
0.1\end{array}$ & $\begin{array}{l}3.7 E+04 \\
4.8 E+04\end{array}$ & $\begin{array}{l}1.5 E-05 \\
2.0 E-05\end{array}$ & 0.1 & $2.0 E+04$ & $5.1 E-08$ & $2.8 E-04$ & $2.8 E-03$ \\
\hline $\begin{array}{l}P 0-207 \\
350 \mathrm{~m}\end{array}$ & $D$ & $\begin{array}{l}0.1 \\
0.1\end{array}$ & $\begin{array}{l}2.4 E+04 \\
2.8 E+04\end{array}$ & $\begin{array}{l}10 E-06 \\
1.1 E-05\end{array}$ & 0.1 & 8000 & $3.4 E-08$ & $1 . I E-04$ & $1.1 E-03$ \\
\hline $\begin{array}{l}\text { Po-210 } \\
138.38 \text { a } \\
\text { Astatine }\end{array}$ & $\underset{\mathbf{W}}{\mathbf{D}}$ & $\begin{array}{l}0.1 \\
0.1\end{array}$ & $\begin{array}{l}0.53 \\
0.58\end{array}$ & $\begin{array}{l}2.2 E-10 \\
2.4 E-10\end{array}$ & 0.1 & 2.6 & $7.3 E-13$ & $3.6 E-08$ & $3.6 \pm-07$ \\
\hline $\begin{array}{l}\text { At }-207 \\
1.80 \mathrm{~h}\end{array}$ & $\begin{array}{l}D \\
W\end{array}$ & $\begin{array}{l}1 \\
1\end{array}$ & $\begin{array}{l}2200 \\
2000\end{array}$ & $\begin{array}{l}9.1 E-07 \\
8.35=07\end{array}$ & 1 & 5700 & $2.8 E-09$ & $7.8 E-05$ & $7.8 \mathrm{E}-04$ \\
\hline $\begin{array}{l}\text { At }-211 \\
7.214 \mathrm{~h}\end{array}$ & $\begin{array}{l}D \\
W\end{array}$ & 1 & $\begin{array}{l}60 \\
48 \\
\end{array}$ & $\begin{array}{l}2.5 E-08 \\
2.0 E-08\end{array}$ & 1 & 120 & $6.8 E-11$ & $1.7 E-06$ & $1.7 E-05$ \\
\hline
\end{tabular}




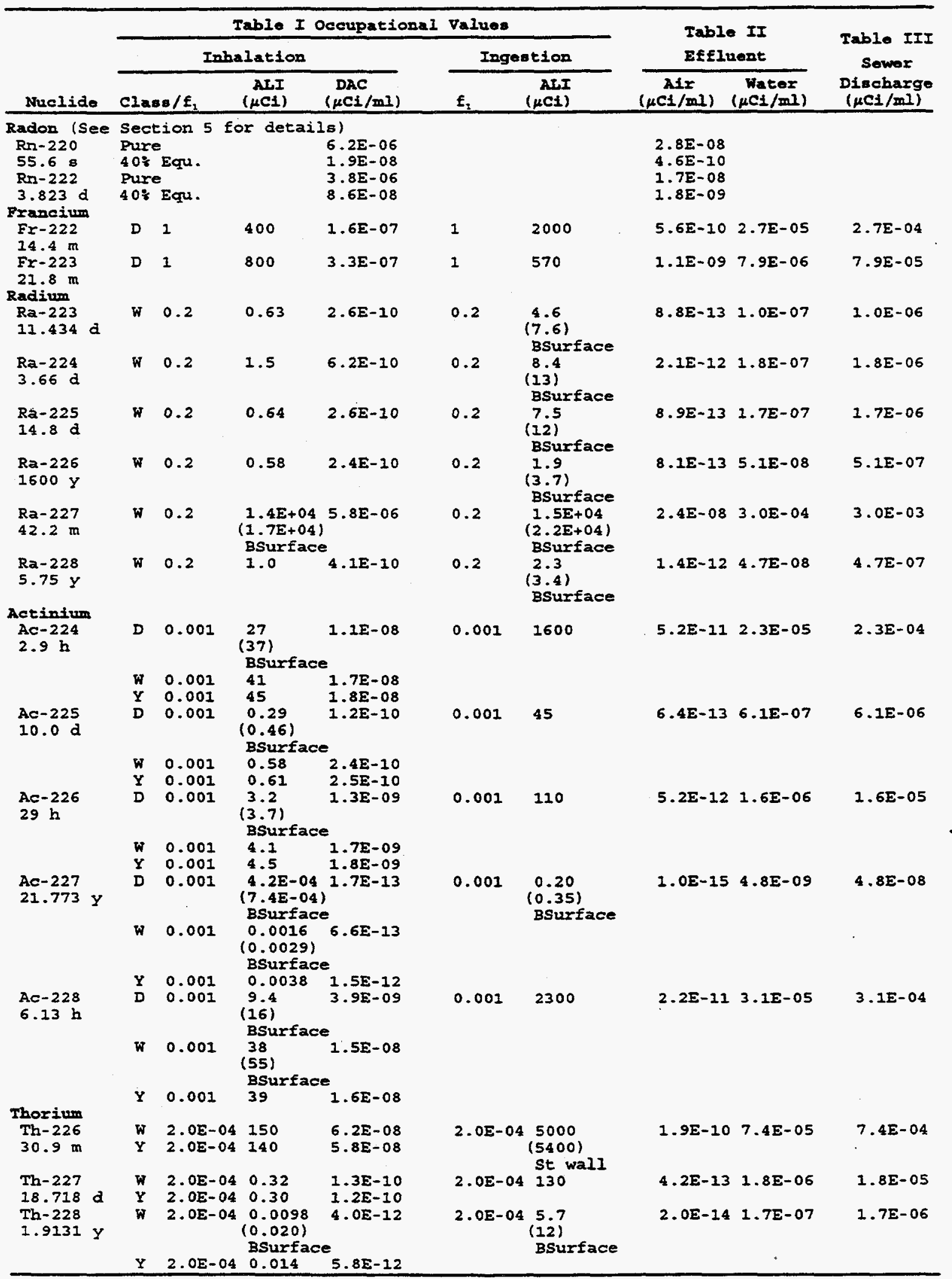




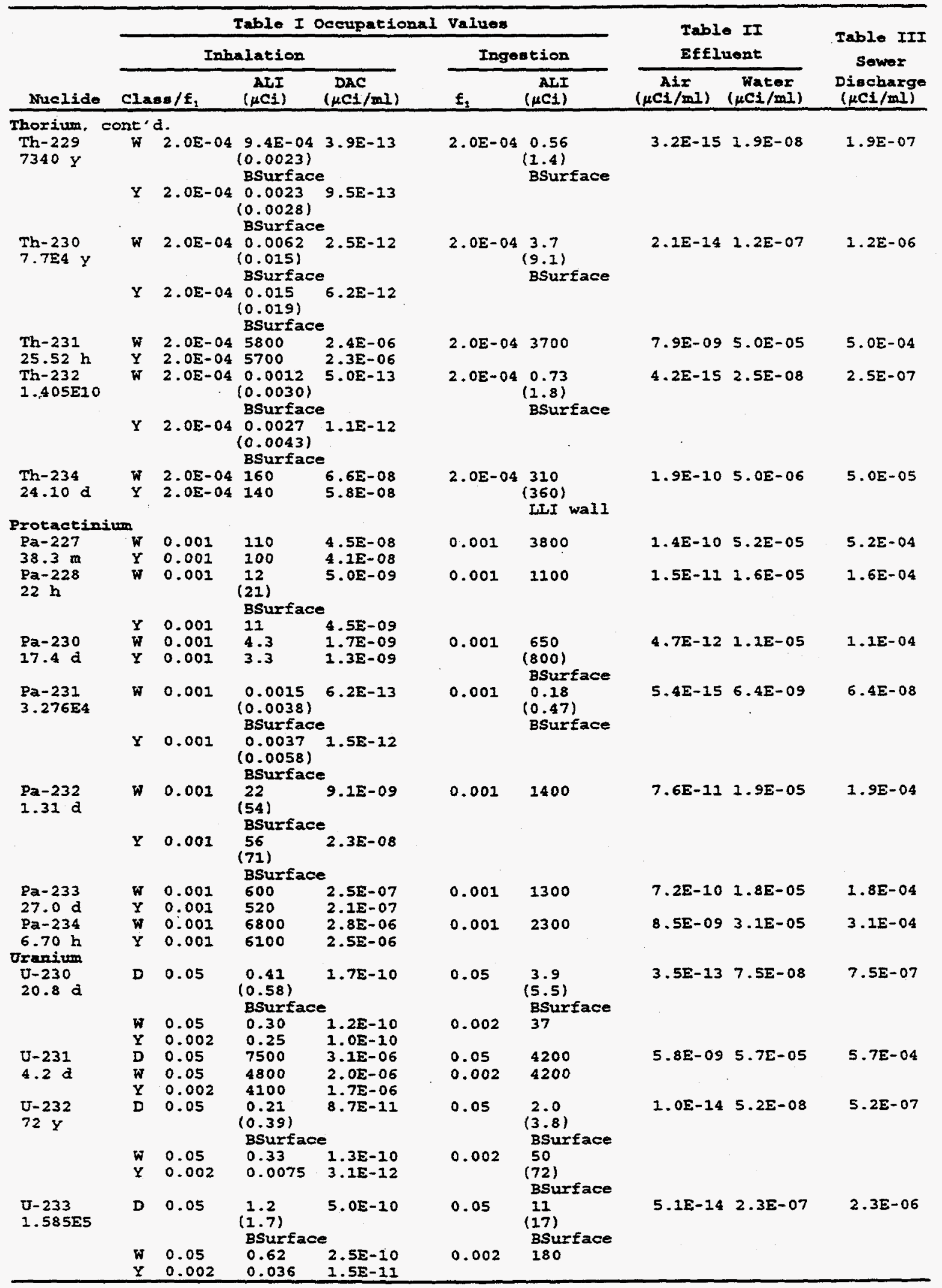




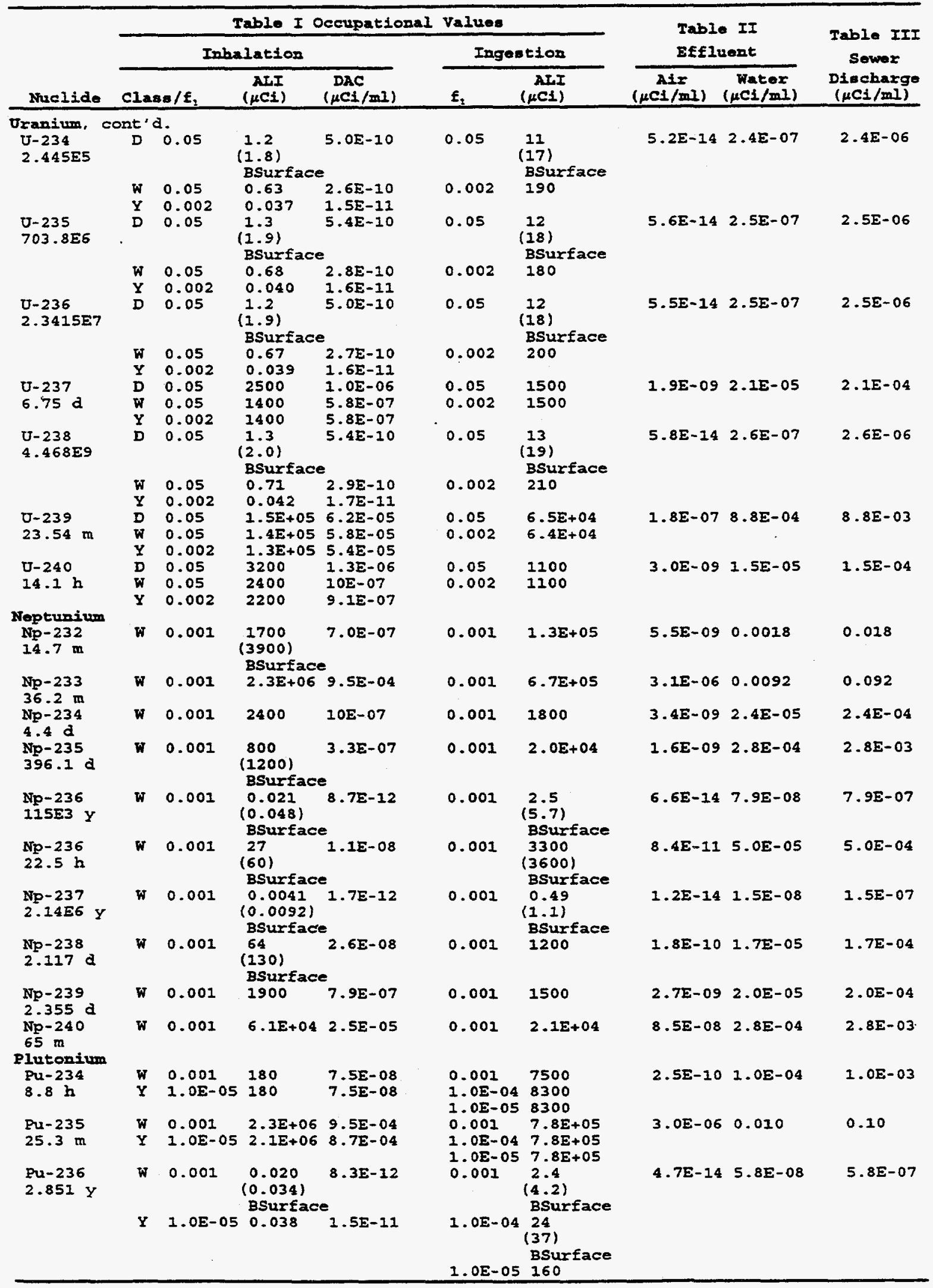




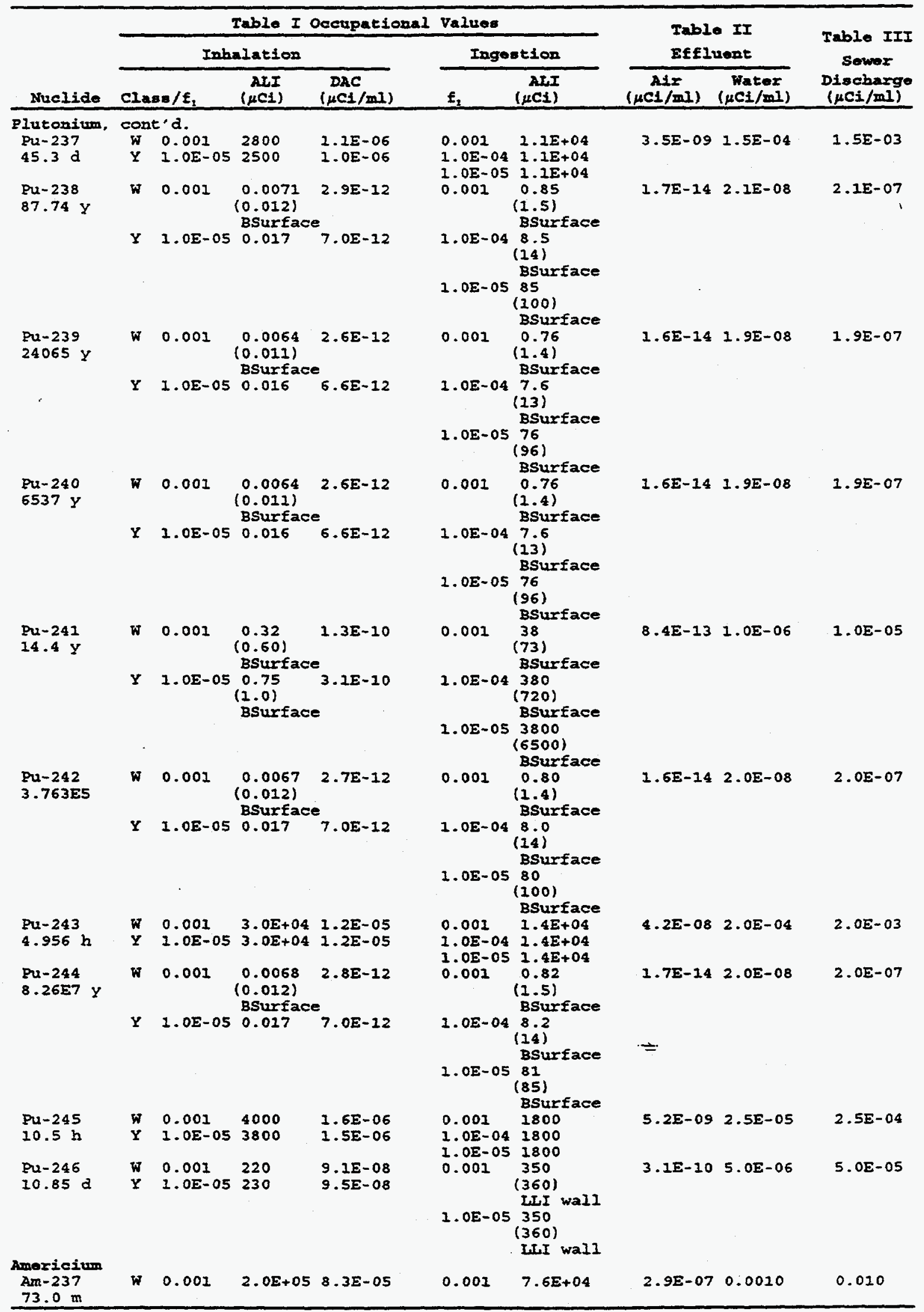




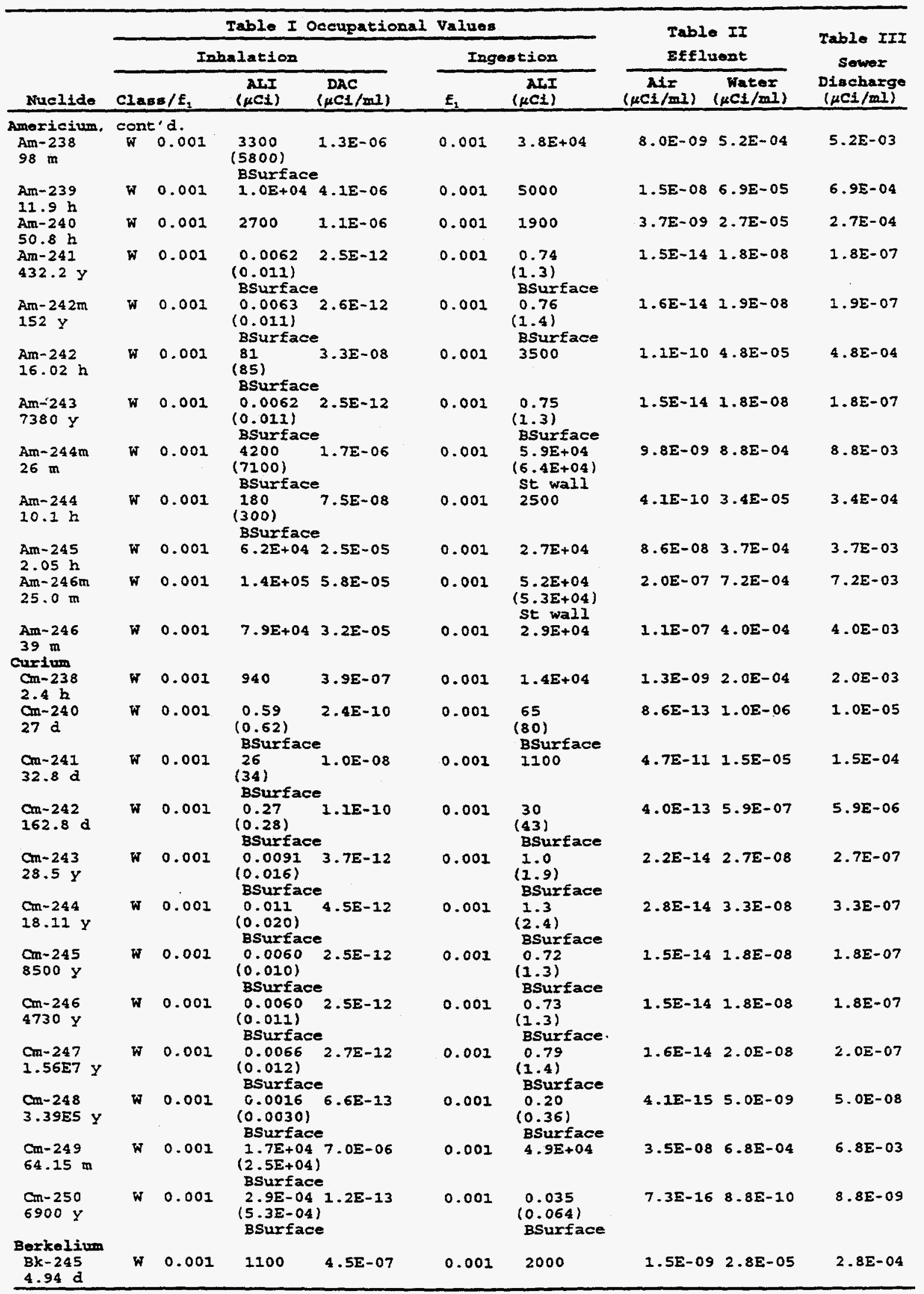




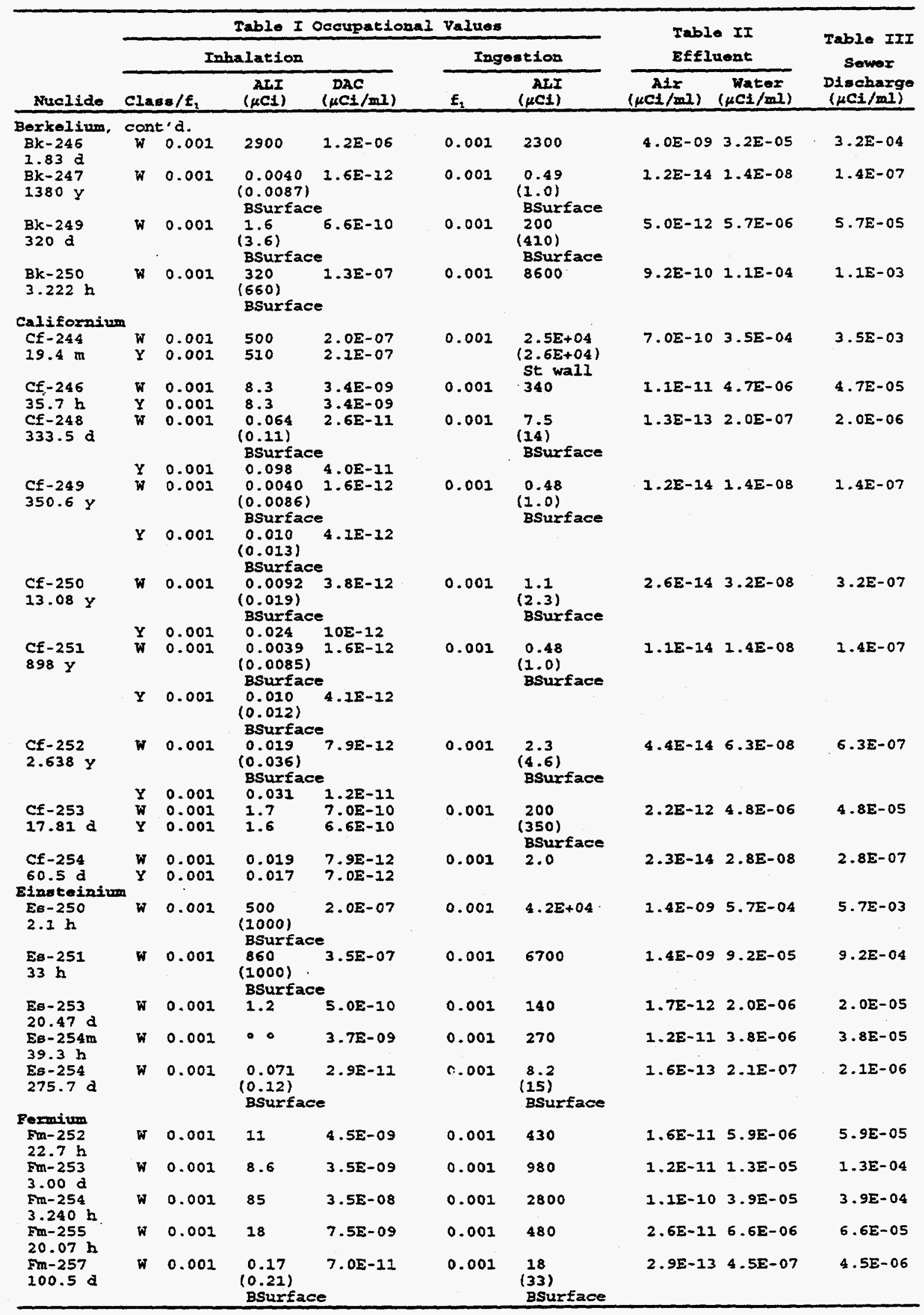




\begin{tabular}{|c|c|c|c|c|c|c|c|c|c|}
\hline \multirow[b]{3}{*}{ Nuclide } & \multicolumn{6}{|c|}{ Table I Occupational Valuea } & \multirow{2}{*}{\multicolumn{2}{|c|}{$\begin{array}{l}\text { Table II } \\
\text { Effluent }\end{array}$}} & \multirow{3}{*}{$\begin{array}{c}\text { Table III } \\
\text { sewer } \\
\text { Diseharge } \\
(\mu \mathrm{Ci} / \mathrm{ml})\end{array}$} \\
\hline & \multicolumn{4}{|c|}{ Inbalation } & \multicolumn{2}{|c|}{ Ingestion } & & & \\
\hline & \multicolumn{2}{|c|}{$C 2 a a_{0} / E_{2}$} & $\begin{array}{r}A r I \\
(\mu C i)\end{array}$ & $\begin{array}{c}\text { DAC } \\
(\mu C \pm / m I)\end{array}$ & $\mathbf{f}_{\mathbf{z}}$ & $\begin{array}{r}\text { AIII } \\
\text { ( } \mu \mathrm{CI})\end{array}$ & $\begin{array}{c}\text { At: } \\
(\mu \mathrm{C} / \mathrm{m} 1)\end{array}$ & $\begin{array}{c}\text { Nacer } \\
(\mu \mathrm{Cl} / \mathrm{ml})\end{array}$ & \\
\hline \multicolumn{10}{|c|}{ Mendelevium } \\
\hline $\begin{array}{l}\text { Md-257 } \\
5.2 \mathrm{~h}\end{array}$ & $w$ & 0.001 & $\begin{array}{l}84 \\
\text { (87) } \\
\text { BSurf }\end{array}$ & 3. $5 E-08$ & 0.001 & 7100 & $1.2 E-10$ & $9.8 \mathrm{E}-05$ & $9.8 E-04$ \\
\hline $\begin{array}{l}\text { Md-258 } \\
55 d\end{array}$ & $W$ & 0.001 & $\begin{array}{c}0.23 \\
(0.30) \\
\text { Bsurf }\end{array}$ & $9.5 E-11$ & 0.001 & $\begin{array}{l}25 \\
(42) \\
\text { BSurface }\end{array}$ & $4.2 E-13$ & $5.8 \mathbf{E}-07$ & $5.8 E-06$ \\
\hline
\end{tabular}

Notes:

1. Submersion refers to the external irradiation of the body while in a semi-infinite cloud of the airborne material.

2. The total effective dose equivalent received during operations with radionuclides of radiological halflives less than two hours might include a significant contribution from external exposure. The $D A C$ values for these radionuclides, other than those designated by Class "Submersion," are based upon the intake by inhalation of the radionuclide into the body and do not include potentially significant contributions to dose equivalent from external exposures. The licensee may substitute a DAC of $1.0 \mathrm{E}-07 \mu \mathrm{Ci} / \mathrm{ml}$ for the listed $D A C$ or derive an appropriate value from Federal Guidance Report 12 to account for the submersion dose prospectively, but should use individual monitoring devices or other radiation measuring instruments that measure external exposure to demonstrate compliance with the limits.

3. For soluble mixtures of U-238, U-234, and U-235 in air, chemical toxicity may be the limiting factors. If the percent by weight (enrichment) of U-235 is not greater that 5 , the average concentration value for a 40 -hour workweek is $0.2 \mathrm{mg} / \mathrm{m}^{3}$. For any enrichment, the product of the average concentration and time of exposure during a 40-hour workweek shall not exceed 8.0E-03 SA $\mu \mathrm{Ci}-\mathrm{hr} / \mathrm{ml}$, where $S A$ is the specific activity of the uranium inhaled. The specific activity for natural uranium is $6.77 \mathrm{E}-07 \mathrm{Ci} / \mathrm{g}-\mathrm{U}$. The specific activity for other mixtures of $\mathrm{U}-238, \mathrm{U}-235$, and U-234, if not known, shall be:

$$
\begin{aligned}
S A C i / g-U & =3.67 \times 10^{-7} \text { for depleted uranium } \\
& =\left[0.4+0.38 \% U-235+0.0034(\% U-235)^{2}\right] \times 10^{-6}, \% U-235>0.72,
\end{aligned}
$$

where $\% U-235$ is the enrichment as a percentage, by weight, of U-235 in the mixture.

4. Mixtures

If a mixture of radionuclides consists of uranium and its daughters in ore dust ( $10 \mu \mathrm{m} A M A D$ particle distribution assumed) prior to chemical separation of the uranium from the ore, the following values may be used for the $D A C$ of the mixture: $6.0 \mathrm{E}-11 \mu \mathrm{Ci} / \mathrm{ml}$ gross alpha activity from U-238, U-234, Th-230, and $\mathrm{Ra}-226 ; 3.0 \mathrm{E}-11 \mu \mathrm{Ci} / \mathrm{ml}$ of natural uranium; or $45 \mu \mathrm{g} / \mathrm{m}^{3}$ of natural uranium.

If the identities and concentrations of each radionuclide in a mixture are known, the limiting values should be derived as follows: determine, for each radionuclide in the mixture, the ratio between the concentration present in the mixture and the $D A C$ for the specific radionuclide when not in a mixture. The sum of such ratios for all radionuclides in the mixture may not exceed 1 . 
Example: If radionuclides $A, B$, and $C$ are present in concentrations $C_{A}, C_{B}$, and $C_{C}$ and if the applicable $D A C s$ are $D A C_{A}, D A C_{B}$, and $D A C_{C}$, respectively, then mixture shall be limited so that the following relationship exists:

$$
\frac{C_{A}}{D A C_{A}}+\frac{C_{B}}{D A C_{B}}+\frac{C_{C}}{D A C_{C}} \leq 1 .
$$

5. Unidentified radionuclides

If the identity of each radionuclide in a mixture is known but the concentration of one or more of the radionuclides in the mixture is not known, the $D A C$ for the mixture shall be the most restrictive $D A C$ of any radionuclide in the mixture.

If the identity of each radionuclide in the mixture is not known, but it is known that certain radionuclides specified in the appendix are not present in the mixture, the inhalation $A L I, D A C$, and effluent and sewage concentrations for the mixture are the lowest value specified in this appendix for any radionuclide that is not known to be absent from the mixture, or

Airborne Activity:

If it is know that $A c-227: D$ and $C m-250$ are not present

If, in addition, it is known that Ac-227: $\mathrm{W} \& \mathrm{Y}, \mathrm{Th}-229$, Th-230: W, Th-232, Pa-231, Np-237, Pu-239:W, Pu-240:W, Pu-242:W, Am-241, Am-242m, Am-243, Cm-245, Cm-246, $\mathrm{Cm}-247$ are not present

If, in addition, it is known that Sm-146, Sm-147, Gd-148, Gd-152, Th-228, Th-230:Y, U-232:Y, U-235:Y, U-236:Y, U-238:Y, Np-236, Pu-236, Pu-238, Pu-239, Pu-240:Y, Pu-242, Pu-242, Cm-243, Cm-244, Cf-248:W, Cf-249:Y, Cf-250, Cf-251:Y, $\mathrm{Cf}-251$ and $\mathrm{Cf}-252$ are not present

If, in addition, it is known that $\mathrm{Pb}-210, \mathrm{Bi}-210 \mathrm{~m}: \mathrm{W}$, Po-210, Ra-226, Ac-225, Th-227, U-230, U-232:D \& W, Pu-241:W, Cm-240, Cm-242, Cf-248:Y, Es-254, Fm-257 and Md-258 are not present

If, in addition, it is known that $\mathrm{Si}-32: \mathrm{Y}, \mathrm{Ti}-44: \mathrm{Y}$, Fe-60:D, Sr-90:Y, Zr-93:D, Cd-113m:D, Cd-113:D, In-115, La-138:D, Lu-176:W, Hf-178m, Hf-182:D \& W, Bi-210m:D, Ra-224, Ra-228, Ac-226, Pa-230, U-233:D \& W, U-234:D \& W, U-235:D \& W, U-236:D \& W, U-238:D \& W, Pu-241:Y, Bk-249, Cf-253 and Es-253 are not present

$\begin{array}{cc}A L I & D A C \\ (\mu \mathrm{Ci}) & (\mu \mathrm{Ci} / \mathrm{ml}) \\ 7.0 \mathrm{E}-04 & 3.0 \mathrm{E}-13 \\ & \\ 7.0 \mathrm{E}-03 & 3.0 \mathrm{E}-12\end{array}$


Table IV. Gastrointestinal Absorption Fractions $\left(f_{1}\right)$ and Lung Clearance Classes for Chemical Compounds

\begin{tabular}{|c|c|c|c|c|c|}
\hline \multirow{2}{*}{ Element } & \multicolumn{3}{|c|}{ Inhalation } & \multicolumn{2}{|c|}{ Ingestion } \\
\hline & Compound & $f_{1}$ & Class & Compound & $f_{1}$ \\
\hline $\begin{array}{l}\text { Actinium } \\
\text { (Ac) }\end{array}$ & $\begin{array}{l}\text { Oxides \& hydroxides } \\
\text { Halides \& nitrates } \\
\text { All others }\end{array}$ & $\begin{array}{ll}1 & 10^{-3} \\
1 & 10^{-3} \\
1 & 10^{-3}\end{array}$ & $\begin{array}{l}\text { Y } \\
\text { W } \\
\mathbf{D}\end{array}$ & All forms & $110^{-3}$ \\
\hline $\begin{array}{l}\text { Aluminum } \\
\text { (Al) }\end{array}$ & $\begin{array}{l}\text { Oxides, hydroxides, } \\
\text { carbides, halides, } \\
\text { nitrates \& elemental } \\
\text { All others }\end{array}$ & 0.01 & D & All forms & 0.01 \\
\hline $\begin{array}{l}\text { Americium } \\
\text { (Am) }\end{array}$ & All forms & $110^{-3}$ & $\mathbf{W}$ & All forms & $110^{-3}$ \\
\hline $\begin{array}{l}\text { Antimony } \\
\text { (Sb) }\end{array}$ & $\begin{array}{l}\text { Oxides, hydroxides, } \\
\text { halides, sulfides, } \\
\text { sulfates \& nitrates } \\
\text { All others }\end{array}$ & 0.01 & $\mathbf{D}$ & $\begin{array}{l}\text { Tartar emetic } \\
\text { All others }\end{array}$ & $\begin{array}{l}0.1 \\
0.01\end{array}$ \\
\hline $\begin{array}{l}\text { Arsenic } \\
\text { (As) }\end{array}$ & All forms & 0.5 & $\mathbf{W}$ & All forms & 0.5 \\
\hline $\begin{array}{l}\text { Astatine } \\
\text { (At) }\end{array}$ & $\begin{array}{l}\text { See halide assignment } \\
\text { of associated element }\end{array}$ & $\begin{array}{l}1 \\
1\end{array}$ & $\begin{array}{l}\mathrm{D} \\
\mathrm{W}\end{array}$ & All forms & 1 \\
\hline $\begin{array}{l}\text { Barium } \\
\text { (Ba) }\end{array}$ & All forms & 0.1 & D & All forms & 0.1 \\
\hline $\begin{array}{l}\text { Berkelium } \\
\text { (Bk) }\end{array}$ & All forms & $110^{-3}$ & W & All forms & $110^{-3}$ \\
\hline $\begin{array}{l}\text { Beryllium } \\
\text { (Be) }\end{array}$ & $\begin{array}{l}\text { Oxides, halides \& } \\
\text { nitrates } \\
\text { All others }\end{array}$ & $\begin{array}{l}510^{-3} \\
510^{-3}\end{array}$ & $\begin{array}{l}\mathbf{Y} \\
\mathbf{W}\end{array}$ & All forms & $510^{-3}$ \\
\hline
\end{tabular}


Table IV. Cont'd

\begin{tabular}{|c|c|c|c|c|c|}
\hline \multirow[b]{2}{*}{ Element } & \multicolumn{3}{|c|}{ Inhalation } & \multicolumn{2}{|l|}{ Ingestion } \\
\hline & Compound & $f_{1}$ & Class & Compound & $f_{1}$ \\
\hline $\begin{array}{l}\text { Calcium } \\
\text { (Ca) }\end{array}$ & All forms & 0.3 & W & All forms & 0.03 \\
\hline $\begin{array}{l}\text { Californium } \\
\text { (Cf) }\end{array}$ & $\begin{array}{l}\text { Oxides, hydroxides } \\
\text { All others }\end{array}$ & $\begin{array}{l}110^{-3} \\
110^{-3}\end{array}$ & $\begin{array}{l}\mathrm{Y} \\
\mathbf{W}\end{array}$ & All forms & $110^{-3}$ \\
\hline $\begin{array}{l}\text { Carbon } \\
\text { (C) }\end{array}$ & $\begin{array}{l}\text { Monoxides } \\
\text { Dioxide } \\
\text { Organic forms }\end{array}$ & $\begin{array}{l}\text { Special } \\
\text { models }\end{array}$ & & Organic forms & 1 \\
\hline $\begin{array}{l}\text { Cerium } \\
\text { (Ce) }\end{array}$ & $\begin{array}{l}\text { Oxides, hydroxides \& } \\
\text { fluorides } \\
\text { All others }\end{array}$ & $\begin{array}{l}310^{-4} \\
310^{-4}\end{array}$ & $\begin{array}{l}\mathrm{Y} \\
\mathrm{W}\end{array}$ & All forms & $310^{-4}$ \\
\hline $\begin{array}{l}\text { Cesium } \\
\text { (Cs) }\end{array}$ & All forms & 1 & D & All forms & 1 \\
\hline $\begin{array}{l}\text { Chlorine } \\
\text { (Cl) }\end{array}$ & $\begin{array}{l}\text { See assignment of } \\
\text { associated element }\end{array}$ & $\begin{array}{l}1 \\
1\end{array}$ & $\begin{array}{l}\mathbf{D} \\
\mathbf{W}\end{array}$ & All forms & 1 \\
\hline $\begin{array}{l}\text { Chromium } \\
(\mathrm{Cr})\end{array}$ & $\begin{array}{l}\text { Oxides \& hydroxides } \\
\text { Halides \& nitrates } \\
\text { All others }\end{array}$ & $\begin{array}{l}0.1 \\
0.1 \\
0.1\end{array}$ & $\begin{array}{l}\mathrm{Y} \\
\mathrm{W} \\
\mathrm{D}\end{array}$ & $\begin{array}{l}\text { Trivalent state } \\
\text { Hexavalent state }\end{array}$ & $\begin{array}{l}0.01 \\
0.1\end{array}$ \\
\hline $\begin{array}{l}\text { Cobalt } \\
\text { (Co) }\end{array}$ & $\begin{array}{l}\text { Oxides, hydroxides, } \\
\text { halides \& nitrates } \\
\text { All others }\end{array}$ & $\begin{array}{l}0.05 \\
0.05\end{array}$ & $\begin{array}{l}\mathrm{Y} \\
\mathrm{W}\end{array}$ & $\begin{array}{l}\text { Oxides, hydroxides \& trace } \\
\text { inorganic } \\
\text { Organic complexes \& other } \\
\text { inorganics }\end{array}$ & $\begin{array}{l}0.05 \\
0.3\end{array}$ \\
\hline $\begin{array}{l}\text { Copper } \\
\text { (Cu) }\end{array}$ & $\begin{array}{l}\text { Oxides \& hydroxides } \\
\text { Sulfites, halides \& } \\
\text { nitrates } \\
\text { All others }\end{array}$ & $\begin{array}{l}0.5 \\
0.5 \\
0.5\end{array}$ & $\begin{array}{l}\mathrm{Y} \\
\mathrm{W} \\
\mathrm{D}\end{array}$ & All forms & 0.5 \\
\hline $\begin{array}{l}\text { Curium } \\
\text { (Cm) }\end{array}$ & All forms & $110^{-3}$ & $\mathbf{w}$ & All forms & $10^{-3}$ \\
\hline $\begin{array}{l}\text { Dysprosium } \\
\text { (Dy) }\end{array}$ & All forms & $310^{-1}$ & $\mathbf{w}$ & All forms & $310^{-4}$ \\
\hline
\end{tabular}


Table IV. Cont'd

\begin{tabular}{|c|c|c|c|c|c|}
\hline \multirow[b]{2}{*}{ Element } & \multicolumn{3}{|c|}{ Inhalation } & \multicolumn{2}{|c|}{ Ingestion } \\
\hline & Compound & $f_{1}$ & Class & Compound & $f_{1}$ \\
\hline $\begin{array}{l}\text { Einsteinium } \\
\text { (Es) }\end{array}$ & All forms & $110^{-3}$ & $\mathrm{~W}$ & All forms & $110^{-3}$ \\
\hline $\begin{array}{l}\text { Erbium } \\
\text { (Er) }\end{array}$ & All forms & $310^{-4}$ & W & All forms & $310^{-4}$ \\
\hline $\begin{array}{l}\text { Europium } \\
\text { (Eu) }\end{array}$ & All forms & $110^{-3}$ & W & All forms & $110^{-3}$ \\
\hline $\begin{array}{l}\text { Fermium } \\
(\mathrm{Fm})\end{array}$ & All forms & $110^{-3}$ & W & All forms & $110^{-3}$ \\
\hline $\begin{array}{l}\text { Fluorine } \\
\text { (F) }\end{array}$ & $\begin{array}{l}\text { See assignment of } \\
\text { associated element }\end{array}$ & $\begin{array}{l}1 \\
1 \\
1\end{array}$ & $\begin{array}{l}\mathrm{D} \\
\mathrm{W} \\
\mathrm{Y}\end{array}$ & All forms & 1 \\
\hline $\begin{array}{l}\text { Francium } \\
\text { (Fr) }\end{array}$ & All forms & 1 & D & All forms & 1 \\
\hline $\begin{array}{l}\text { Gadolinium } \\
\text { (Gd) }\end{array}$ & $\begin{array}{l}\text { Oxides, hydroxides \& } \\
\text { fluorides } \\
\text { All others }\end{array}$ & $\begin{array}{l}310^{-4} \\
310^{-4}\end{array}$ & $\begin{array}{l}\text { W } \\
\text { D }\end{array}$ & All forms & $310^{-4}$ \\
\hline $\begin{array}{l}\text { Gallium } \\
\text { (Ga) }\end{array}$ & $\begin{array}{l}\text { Oxides, hydroxides, } \\
\text { carbides, halides \& } \\
\text { nitrates } \\
\text { All others }\end{array}$ & $110^{-3}$ & D & All forms & $110^{-3}$ \\
\hline $\begin{array}{l}\text { Germanium } \\
(\mathrm{Ge})\end{array}$ & $\begin{array}{l}\text { Oxides, sulfides \& } \\
\text { halides } \\
\text { All others }\end{array}$ & $\begin{array}{l}1 \\
1\end{array}$ & $\begin{array}{l}\text { W } \\
\mathrm{D}\end{array}$ & All forms & 1 \\
\hline $\begin{array}{l}\text { Gold } \\
\text { (Au) }\end{array}$ & $\begin{array}{l}\text { Oxides \& hydroxides } \\
\text { Halides \& nitrates } \\
\text { All others }\end{array}$ & $\begin{array}{l}0.1 \\
0.1 \\
0.1\end{array}$ & $\begin{array}{l}\text { Y } \\
\text { W } \\
D\end{array}$ & All forms & 0.1 \\
\hline
\end{tabular}


Table IV. Cont'd

\begin{tabular}{|c|c|c|c|c|c|}
\hline \multirow[b]{2}{*}{ Element } & \multicolumn{3}{|c|}{ Inhalation } & \multicolumn{2}{|c|}{ Ingestion } \\
\hline & Compound & $f_{1}$ & Class & Compound & $f_{1}$ \\
\hline $\begin{array}{l}\text { Hafnium } \\
\text { (Hf) }\end{array}$ & $\begin{array}{l}\text { Oxides, hydroxides } \\
\text { halides, carbides \& } \\
\text { nitrates } \\
\text { All other }\end{array}$ & $\begin{array}{l}210^{-3} \\
210^{-3}\end{array}$ & W & All forms & $210^{-3}$ \\
\hline $\begin{array}{l}\text { Holmium } \\
\text { (Ho) }\end{array}$ & All forms & $310^{-4}$ & W & All forms & $310^{-4}$ \\
\hline $\begin{array}{l}\text { Hydrogen } \\
\text { (H) }\end{array}$ & $\begin{array}{l}\text { Water vapor } \\
\text { Elemental }\end{array}$ & $\begin{array}{l}1 \\
\text { Special } \\
\text { model }\end{array}$ & & All forms & 1 \\
\hline $\begin{array}{l}\text { Indium } \\
\text { (In) }\end{array}$ & $\begin{array}{l}\text { Oxides, hydroxides, } \\
\text { halides \& nitrates } \\
\text { All others }\end{array}$ & $\begin{array}{l}0.02 \\
0.02\end{array}$ & $\begin{array}{l}\text { W } \\
\text { D }\end{array}$ & All forms & 0.02 \\
\hline $\begin{array}{l}\text { Iodine } \\
\text { (I) }\end{array}$ & All forms & 1 & D & All forms & 1 \\
\hline $\begin{array}{l}\text { Iridium } \\
\text { (Ir) }\end{array}$ & $\begin{array}{l}\text { Oxides \& hydroxides } \\
\text { Halides, nitrates \& } \\
\text { metallic form } \\
\text { All others }\end{array}$ & $\begin{array}{l}0.01 \\
0.01 \\
0.01\end{array}$ & $\begin{array}{l}\text { Y } \\
\text { W } \\
\text { D }\end{array}$ & All forms & 0.01 \\
\hline $\begin{array}{l}\text { Iron } \\
(\mathrm{Fe})\end{array}$ & $\begin{array}{l}\text { Oxides, hydroxides \& } \\
\text { halides } \\
\text { All others }\end{array}$ & $\begin{array}{l}0.1 \\
0.1\end{array}$ & $\begin{array}{l}\text { W } \\
\text { D }\end{array}$ & All forms & 0.1 \\
\hline $\begin{array}{l}\text { Lanthanum } \\
\text { (La) }\end{array}$ & $\begin{array}{l}\text { Oxides \& hydroxides } \\
\text { All others }\end{array}$ & $\begin{array}{l}110^{-3} \\
110^{-3}\end{array}$ & $\begin{array}{l}\text { W } \\
\text { D }\end{array}$ & All forms & $110^{-3}$ \\
\hline $\begin{array}{l}\text { Lead } \\
(\mathrm{Pb})\end{array}$ & All forms & 0.2 & D & All forms & 0.2 \\
\hline $\begin{array}{l}\text { Lutetium } \\
\text { (Lu) }\end{array}$ & $\begin{array}{l}\text { Oxides, hydroxides \& } \\
\text { fluorides } \\
\text { All others }\end{array}$ & $\begin{array}{l}310^{-4} \\
310^{-4}\end{array}$ & $\begin{array}{l}\mathbf{Y} \\
\mathbf{W}\end{array}$ & All forms & $310^{-4}$ \\
\hline
\end{tabular}


Table IV. Cont'd

\begin{tabular}{|c|c|c|c|c|c|}
\hline \multirow[b]{2}{*}{ Element } & \multicolumn{3}{|l|}{ Inhalation } & \multicolumn{2}{|c|}{ Ingestion } \\
\hline & Compound & $f_{1}$ & Class & Compound & $f_{1}$ \\
\hline $\begin{array}{l}\text { Magnesium } \\
(\mathrm{Mg})\end{array}$ & $\begin{array}{l}\text { Oxides, hydroxides, } \\
\text { carbides, halides \& } \\
\text { nitrates } \\
\text { All others }\end{array}$ & 0.5 & D & All forms & 0.5 \\
\hline $\begin{array}{l}\text { Manganese } \\
(\mathrm{Mn})\end{array}$ & $\begin{array}{l}\text { Oxides, hydroxides, } \\
\text { halides \& nitrates } \\
\text { All others }\end{array}$ & $\begin{array}{l}0.1 \\
0.1\end{array}$ & $\begin{array}{l}\text { W } \\
\text { D }\end{array}$ & All forms & 0.1 \\
\hline $\begin{array}{l}\text { Mendelevium } \\
\text { (Md) }\end{array}$ & All forms & $110^{-3}$ & W & All forms & $110^{-3}$ \\
\hline $\begin{array}{l}\text { Mercury } \\
(\mathrm{Hg})\end{array}$ & $\begin{array}{l}\text { Oxides, hydroxides, } \\
\text { halides, nitrates \& } \\
\text { sulfides } \\
\text { Sulfates } \\
\text { Organic forms } \\
\text { Vapors }\end{array}$ & $\begin{array}{l}0.02 \\
0.02 \\
1 \text { Special } \\
\text { model }\end{array}$ & $\begin{array}{l}D \\
D\end{array}$ & $\begin{array}{l}\text { All inorganic forms } \\
\text { Methyl mercury } \\
\text { Other organic forms }\end{array}$ & $\begin{array}{l}0.02 \\
1 \\
0.4\end{array}$ \\
\hline $\begin{array}{l}\text { Molybdenum } \\
\text { (Mo) }\end{array}$ & $\begin{array}{l}\text { Oxides, hydroxides \& } \\
\mathrm{MoS}_{2} \\
\text { All others }\end{array}$ & $\begin{array}{l}0.05 \\
0.8\end{array}$ & $\begin{array}{l}\mathbf{Y} \\
\mathbf{D}\end{array}$ & $\begin{array}{l}\mathrm{MoS}_{2} \\
\text { All others }\end{array}$ & $\begin{array}{l}0.05 \\
0.8\end{array}$ \\
\hline $\begin{array}{l}\text { Neodymium } \\
\text { (Nd) }\end{array}$ & $\begin{array}{l}\text { Oxides, hydroxides, } \\
\text { carbides \& fluorides } \\
\text { All others }\end{array}$ & $\begin{array}{l}310^{-4} \\
310^{-4}\end{array}$ & $\begin{array}{l}\mathbf{Y} \\
\mathbf{W}\end{array}$ & All forms & $310^{-4}$ \\
\hline $\begin{array}{l}\text { Neptunium } \\
\text { (Np) }\end{array}$ & All forms & $110^{-3}$ & $\mathbf{W}$ & All forms & $110^{-3}$ \\
\hline $\begin{array}{l}\text { Nickel } \\
\text { (Ni) }\end{array}$ & $\begin{array}{l}\text { Oxides, hydroxides \& carbides } \\
\text { All others } \\
\text { Vapors }\end{array}$ & $\begin{array}{l}0.05 \\
0.05 \\
\text { Special } \\
\text { model }\end{array}$ & $\begin{array}{l}\mathbf{W} \\
\mathbf{D}\end{array}$ & All forms & 0.05 \\
\hline $\begin{array}{l}\text { Niobium } \\
\text { (Nb) }\end{array}$ & $\begin{array}{l}\text { Oxides \& hydroxides } \\
\text { All others }\end{array}$ & $\begin{array}{l}0.01 \\
0.01\end{array}$ & $\begin{array}{l}\mathbf{Y} \\
\mathbf{W}\end{array}$ & All forms & 0.01 \\
\hline
\end{tabular}


Table IV. Cont'd

\begin{tabular}{|c|c|c|c|c|c|c|}
\hline \multirow[b]{2}{*}{ Element } & \multicolumn{4}{|c|}{ Inhalation } & \multicolumn{2}{|c|}{ Ingestion } \\
\hline & Compound & & $f_{1}$ & Class & Compound & $f_{1}$ \\
\hline $\begin{array}{l}\text { Osmium } \\
\text { (Os) }\end{array}$ & $\begin{array}{l}\text { Oxides \& hydroxides } \\
\text { Halides \& nitrates } \\
\text { All others }\end{array}$ & & $\begin{array}{l}0.01 \\
0.01 \\
0.01\end{array}$ & $\begin{array}{l}Y \\
W \\
D\end{array}$ & All forms & 0.01 \\
\hline $\begin{array}{l}\text { Palladium } \\
\text { (Pd) }\end{array}$ & $\begin{array}{l}\text { Oxides \& hydroxides } \\
\text { Nitrates } \\
\text { All others }\end{array}$ & & $\begin{array}{l}510^{-3} \\
510^{-3} \\
510^{-3}\end{array}$ & $\begin{array}{l}Y \\
W \\
D\end{array}$ & All forms & $510^{-3}$ \\
\hline $\begin{array}{l}\text { Phosphorus } \\
\text { (P) }\end{array}$ & $\begin{array}{l}\text { Phosphates of } \\
\text { element } \\
\text { All others }\end{array}$ & particular & $\begin{array}{l}0.8 \\
0.8\end{array}$ & $\begin{array}{l}\text { W } \\
\text { D }\end{array}$ & All forms & 0.8 \\
\hline $\begin{array}{l}\text { Platinum } \\
\text { (Pt) }\end{array}$ & All forms & & 0.01 & D & All forms & 0.01 \\
\hline $\begin{array}{l}\text { Plutonium } \\
\text { (Pu) }\end{array}$ & $\begin{array}{l}\text { Oxides } \\
\text { All others }\end{array}$ & & $\begin{array}{l}110^{-5} \\
110^{-3}\end{array}$ & $\begin{array}{l}\mathrm{Y} \\
\mathrm{W}\end{array}$ & $\begin{array}{l}\text { Oxides } \\
\text { Nitrates } \\
\text { Others }\end{array}$ & $\begin{array}{l}110^{-5} \\
110^{-4} \\
110^{-3}\end{array}$ \\
\hline $\begin{array}{l}\text { Polonium } \\
\text { (Po) }\end{array}$ & $\begin{array}{l}\text { Oxides, hydroxides \& } \\
\text { nitrates } \\
\text { All others }\end{array}$ & & $\begin{array}{l}0.1 \\
0.1\end{array}$ & $\begin{array}{l}\text { W } \\
\text { D }\end{array}$ & All forms & 0.1 \\
\hline $\begin{array}{l}\text { Potassium } \\
\text { (K) }\end{array}$ & All forms & & 1 & D & All forms & 1 \\
\hline $\begin{array}{l}\text { Praseodymium } \\
\text { (Pr) }\end{array}$ & $\begin{array}{l}\text { Oxides, hydroxides, } \\
\text { \& fluorides } \\
\text { All others }\end{array}$ & carbides, & $\begin{array}{l}310^{-4} \\
310^{-4}\end{array}$ & $\begin{array}{l}\mathrm{Y} \\
\mathrm{W}\end{array}$ & All forms & $310^{-4}$ \\
\hline $\begin{array}{l}\text { Promethium } \\
\text { (Pm) }\end{array}$ & $\begin{array}{l}\text { Oxides, hydroxides, } \\
\text { carbides, \& fluorides } \\
\text { All others }\end{array}$ & & $\begin{array}{l}310^{-4} \\
310^{-4}\end{array}$ & $\begin{array}{l}\mathrm{Y} \\
\mathrm{W}\end{array}$ & All forms & $310^{-4}$ \\
\hline $\begin{array}{l}\text { Protactinium } \\
(\mathrm{Pa})\end{array}$ & $\begin{array}{l}\text { Oxides \& hydroxides } \\
\text { All others }\end{array}$ & & $\begin{array}{l}110^{-3} \\
110^{-3}\end{array}$ & $\begin{array}{l}\mathrm{Y} \\
\mathbf{W}\end{array}$ & All forms & $110^{-3}$ \\
\hline
\end{tabular}


Table IV. Cont'd

\begin{tabular}{|c|c|c|c|c|c|}
\hline \multirow[b]{2}{*}{ Element } & \multicolumn{3}{|c|}{ Inhalation } & \multicolumn{2}{|c|}{ Ingestion } \\
\hline & Compound & $f_{1}$ & Class & Compound & $f_{1}$ \\
\hline $\begin{array}{l}\text { Radium } \\
\text { (Ra) }\end{array}$ & All forms & 0.2 & W & All forms & 0.2 \\
\hline $\begin{array}{l}\text { Rhenium } \\
\text { (Re) }\end{array}$ & $\begin{array}{l}\text { Oxides, hydroxides, } \\
\text { nitrates } \\
\text { All others }\end{array}$ & $\begin{array}{r}\text { halides \& } 0.8 \\
0.8\end{array}$ & $\begin{array}{l}\text { W } \\
\text { D }\end{array}$ & All forms & 0.8 \\
\hline $\begin{array}{l}\text { Rhodium } \\
\text { (Rh) }\end{array}$ & $\begin{array}{l}\text { Oxides \& hydroxides } \\
\text { Halides } \\
\text { All others }\end{array}$ & $\begin{array}{l}0.05 \\
0.05 \\
0.05\end{array}$ & $\begin{array}{l}\text { Y } \\
\text { W } \\
\text { D }\end{array}$ & All forms & 0.05 \\
\hline $\begin{array}{l}\text { Rubidium } \\
\text { (Rb) }\end{array}$ & All forms & 1 & $\mathrm{D}$ & All forms & 1 \\
\hline $\begin{array}{l}\text { Ruthenium } \\
\text { (Ru) }\end{array}$ & $\begin{array}{l}\text { Oxides \& hydroxides } \\
\text { Halides } \\
\text { All others }\end{array}$ & $\begin{array}{l}0.05 \\
0.05 \\
0.05\end{array}$ & $\begin{array}{l}\text { Y } \\
\text { W } \\
\text { D }\end{array}$ & All forms & 0.05 \\
\hline $\begin{array}{l}\text { Samarium } \\
\text { (Sm) }\end{array}$ & All forms & $310^{-4}$ & $\mathbf{W}$ & All forms & $310^{-4}$ \\
\hline $\begin{array}{l}\text { Scandium } \\
\text { (Sc) }\end{array}$ & All forms & $110^{-4}$ & $\mathbf{Y}$ & All forms & $110^{-4}$ \\
\hline $\begin{array}{l}\text { Selenium } \\
\text { (Se) }\end{array}$ & $\begin{array}{l}\text { Oxides, hydroxides, } \\
\text { carbides \& elemental } \\
\text { All others }\end{array}$ & $\begin{array}{l}0.8 \\
0.8\end{array}$ & $\begin{array}{l}\text { W } \\
\text { D }\end{array}$ & $\begin{array}{l}\text { Elemental } \\
\text { All others }\end{array}$ & $\begin{array}{l}0.05 \\
0.8\end{array}$ \\
\hline $\begin{array}{l}\text { Silicon } \\
\text { (Si) }\end{array}$ & $\begin{array}{l}\text { Ceramic forms } \\
\text { Oxides, hydroxides, } \\
\text { carbides, \& nitrates } \\
\text { All others }\end{array}$ & $\begin{array}{l}0.01 \\
0.01 \\
0.01\end{array}$ & $\begin{array}{l}\mathrm{Y} \\
\mathrm{W} \\
\mathrm{D}\end{array}$ & All compounds & 0.01 \\
\hline $\begin{array}{l}\text { Silver } \\
\text { (Ag) }\end{array}$ & $\begin{array}{l}\text { Oxides \& hydroxides } \\
\text { Nitrates \& sulfides } \\
\text { All others }\end{array}$ & $\begin{array}{l}0.05 \\
0.05 \\
0.05\end{array}$ & $\begin{array}{l}\mathrm{Y} \\
\mathrm{W} \\
\mathrm{D}\end{array}$ & All forms & 0.05 \\
\hline $\begin{array}{l}\text { Sodium } \\
\text { (Na) }\end{array}$ & All forms & 1 & D & All forms & 1 \\
\hline
\end{tabular}


Table IV. Cont'd

\begin{tabular}{|c|c|c|c|c|c|}
\hline \multirow[b]{2}{*}{ Element } & \multicolumn{3}{|c|}{ Inhalation } & \multicolumn{2}{|c|}{ Ingestion } \\
\hline & Compound & $f_{1}$ & Class & Compound & $f_{1}$ \\
\hline $\begin{array}{l}\text { Strontium } \\
\text { (Sr) }\end{array}$ & $\begin{array}{l}\mathrm{SrTiO}_{3} \\
\text { All others }\end{array}$ & $\begin{array}{l}0.01 \\
0.3\end{array}$ & $\begin{array}{l}\mathrm{Y} \\
\mathrm{D}\end{array}$ & $\begin{array}{l}\text { Soluble salts } \\
\mathrm{SrTiO}_{3}\end{array}$ & $\begin{array}{l}0.3 \\
0.01\end{array}$ \\
\hline $\begin{array}{l}\text { Sulfur } \\
\text { (S) }\end{array}$ & $\begin{array}{l}\text { Sulfates \& sulfides of } \\
\text { associated elements } \\
\text { Elemental } \\
\text { Gases }\end{array}$ & $\begin{array}{l}0.8 \\
0.8 \\
\text { Special } \\
\text { model }\end{array}$ & $\begin{array}{l}D \\
W \\
W\end{array}$ & $\begin{array}{l}\text { All inorganic forms } \\
\text { Elemental }\end{array}$ & $\begin{array}{l}0.8 \\
0.1\end{array}$ \\
\hline $\begin{array}{l}\text { Tantalum } \\
\text { (Ta) }\end{array}$ & $\begin{array}{l}\text { Oxides, hydroxides, } \\
\text { halides, carbides, } \\
\text { nitrates \& nitrides } \\
\text { All others }\end{array}$ & $11^{-3}$ & $\mathbf{W}$ & All forms & $110^{-3}$ \\
\hline $\begin{array}{l}\text { Technetium } \\
\text { (Tc) }\end{array}$ & $\begin{array}{l}\text { Oxides, hydroxides, } \\
\text { halides \& nitrates } \\
\text { All others }\end{array}$ & $\begin{array}{l}0.8 \\
0.8\end{array}$ & $\begin{array}{l}\text { W } \\
\text { D }\end{array}$ & All forms & 0.8 \\
\hline $\begin{array}{l}\text { Tellurium } \\
\text { (Te) }\end{array}$ & $\begin{array}{l}\text { Oxides, hydroxides \& } \\
\text { nitrates } \\
\text { All others }\end{array}$ & $\begin{array}{l}0.2 \\
0.2\end{array}$ & $\begin{array}{l}\mathbf{W} \\
\mathbf{D}\end{array}$ & All forms & 0.2 \\
\hline $\begin{array}{l}\text { Terbium } \\
\text { (Tb) }\end{array}$ & All forms & $310^{-4}$ & $\mathbf{W}$ & All forms & $310^{-4}$ \\
\hline $\begin{array}{l}\text { Thallium } \\
\text { (TI) }\end{array}$ & All forms & 1 & $\mathrm{D}$ & All forms & 1 \\
\hline $\begin{array}{l}\text { Thorium } \\
\text { (Th) }\end{array}$ & $\begin{array}{l}\text { Oxides \& hydroxides } \\
\text { All others }\end{array}$ & $\begin{array}{l}210^{-4} \\
210^{-4}\end{array}$ & $\begin{array}{l}\mathbf{Y} \\
\mathbf{W}\end{array}$ & All forms & $2.10^{4}$ \\
\hline $\begin{array}{l}\text { Thulium } \\
\text { (Tm) }\end{array}$ & All forms & $310^{-4}$ & $\mathbf{W}$ & All forms & $310^{-4}$ \\
\hline $\begin{array}{l}\text { Tin } \\
\text { (Sn) }\end{array}$ & $\begin{array}{l}\text { Oxides, hydroxides, } \\
\text { halides, nitrates, } \\
\text { sulfides \& } \mathrm{Sn}_{3}\left(\mathrm{PO}_{4}\right)_{4} \\
\text { All others }\end{array}$ & 0.02 & $\mathbf{w}$ & All forms & 0.02 \\
\hline
\end{tabular}


Table IV. Cont'd

\begin{tabular}{|c|c|c|c|c|c|}
\hline \multirow[b]{2}{*}{ Element } & \multicolumn{3}{|l|}{ Inhalation } & \multicolumn{2}{|c|}{ Ingestion } \\
\hline & Compound & $\mathbf{f}_{1}$ & Class & Compound & $f_{1}$ \\
\hline $\begin{array}{l}\text { Titanium } \\
\text { (Ti) }\end{array}$ & $\begin{array}{l}\mathrm{SrTiO}_{3} \\
\text { Oxides, hydroxides, } \\
\text { carbides, halides \& } \\
\text { nitrates } \\
\text { All others }\end{array}$ & $\begin{array}{l}0.01 \\
0.01\end{array}$ & $\begin{array}{l}\mathbf{Y} \\
\mathbf{W}\end{array}$ & All forms & 0.01 \\
\hline $\begin{array}{l}\text { Tungsten } \\
\text { (W) }\end{array}$ & All forms & 0.3 & D & $\begin{array}{l}\text { Tungstic acid } \\
\text { All others }\end{array}$ & $\begin{array}{l}0.01 \\
0.3\end{array}$ \\
\hline $\begin{array}{l}\text { Uranium } \\
\text { (U) }\end{array}$ & $\begin{array}{l}\mathrm{UO}_{2}, \mathrm{U}_{3} \mathrm{O}_{8} \\
\mathrm{UO}_{3}, \mathrm{UF}_{4} \& \mathrm{UCl}_{4} \\
\mathrm{UF}_{6}, \mathrm{UO}_{2} \mathrm{~F}_{2} \& \mathrm{UO}_{2}\left(\mathrm{NO}_{3}\right)_{2}\end{array}$ & $\begin{array}{l}210^{-3} \\
0.05 \\
0.05\end{array}$ & $\begin{array}{l}Y \\
W \\
D\end{array}$ & $\begin{array}{l}\text { Hexavalent } \\
\text { Insoluble forms }\end{array}$ & $\begin{array}{l}0.05 \\
210^{-3}\end{array}$ \\
\hline $\begin{array}{l}\text { Vanadium } \\
\text { (V) }\end{array}$ & $\begin{array}{l}\text { Oxides, hydroxides, carbides, \& } \\
\text { halides } \\
\text { All others }\end{array}$ & $\begin{array}{l}0.01 \\
0.01\end{array}$ & $\begin{array}{l}\mathbf{W} \\
\mathbf{D}\end{array}$ & All forms & 0.01 \\
\hline $\begin{array}{l}\text { Ytterbium } \\
\text { (Yb) }\end{array}$ & $\begin{array}{l}\text { Oxides, hydroxides \& } \\
\text { fluorides } \\
\text { All others }\end{array}$ & $\begin{array}{l}310^{-4} \\
310^{-4}\end{array}$ & $\begin{array}{l}\mathbf{Y} \\
\mathbf{W}\end{array}$ & All forms & $310^{-4}$ \\
\hline $\begin{array}{l}\text { Ytrium } \\
(Y)\end{array}$ & $\begin{array}{l}\text { Oxides \& hydroxides } \\
\text { All others }\end{array}$ & $\begin{array}{l}110^{-4} \\
110^{-4}\end{array}$ & $\begin{array}{l}\mathbf{Y} \\
\mathbf{W}\end{array}$ & All forms & $110^{-4}$ \\
\hline $\begin{array}{l}\text { Zinc } \\
(\mathrm{Zn})\end{array}$ & All forms & 0.5 & $\mathbf{Y}$ & All forms & 0.5 \\
\hline $\begin{array}{l}\text { Zirconium } \\
\text { (Zr) }\end{array}$ & $\begin{array}{l}\text { Carbides } \\
\text { Oxides, hydroxides, } \\
\text { halides, \& nitrates } \\
\text { All others }\end{array}$ & $\begin{array}{l}210^{-3} \\
210^{-3} \\
210^{-3}\end{array}$ & $\begin{array}{l}\mathbf{Y} \\
\mathbf{W} \\
\mathbf{D}\end{array}$ & All forms & $210^{-3}$ \\
\hline
\end{tabular}




\section{INTERNAL DISTRIBUTION}

1. B. A. Berven

2. J. S. Bogard

3-7. K. F. Eckerman

8. C. E. Easterly

9. R. N. Hamm

13. G. D. Kerr

14. D. C. Kocher

15. R. W. Leggett

16. Po-Yung Lu

17. C. A. Little

18. D. A. McLaughlin
19. J. A Miller

20. D. E. Reichle

21. P. S. Rohwer

22. J. C. Ryman

23. A. L. Sjoreen

24. C. C. Travis

25. R. C. Ward

26. Central Research Library

27. ORNL Y-12 Research Library

28. Laboratory Records Department

29. Laboratory Records, ORNL (RC)

30. ORNL Patent Office

\section{EXTERNAL DISTRIBUTION}

31. Assistant Manager of Energy Research and Development, U. S. Department of Energy, Oak Ridge Operations Office, P. O. Box 2001, Oak Ridge, TN 37831-8600

32. B. B. Boecker, Inhalation Toxicology Research Institute, Lovelace Biomedical and Environmental Research Institute, P. O. Box 5890, Albuquerque, NM 87185

33. W. E. Bolch, 205 Nuclear Science Center, University of Florida, Gainesville, FL 32611

34. A. Bouville, National Cancer Institute, Radiation Effects Branch, Executive Plaza North, Suite 530, Bethesda, MD 20892

35. L. Camper, Office of Nuclear Materials Safety and Safeguards, Division of Waste Management, Nuclear Regulatory Commission, Washington DC 20555

36. D. A. Cool, Division of Industrial and Medical Nuclear Safety, Office of Nuclear Safety and Safeguards, U. S. Nuclear Regulatory Commission, Washington, DC 20555

37. F. J. Congel, Incident Response Division, Office for Analysis and Evaluation of Operational Data, U. S. Nuclear Regulatory Commission, Washington, DC 20555

38. B. K. Grimes, Division of Reactor Projects, Office of Nuclear Reactor Regulation, U. S. Nuclear Regulatory Commission, Washington, DC 20555

39. J. E. Glenn, Division of Regulatory Application, Office of Nuclear Regulatory Research, U. S. Nuclear Regulatory Commission, Washington, DC 20555 
40. J. T. Greeves, Division of Industrial and Medical Nuclear Safety, Office of Nuclear Materials Safety and Safeguards, U. S. Nuclear Regulatory Commission, Washington, DC 20555

41. K. J. Kearfott, Nuclear Engineering, University of Michigan, 108 Cooley Lab, North Campus, Ann Arbor, MI 48109-2104

42. M. W. Lantz, Arizona Public Service Co., P.O. Box 52034, MS 6281, Phoeniz, AZ 85072

43. T. T. Martin, Division of Reactor Projects, Office of Nuclear Reactor Regulation, U. S. Nuclear Regulatory Commission, Washington, DC 20555

44. C. L. Miller, Office of Nuclear Reactor Regulation, U. S. Nuclear Regulatory Commission, Washington, DC 20555

45. B. M. Morris, Division of Regulatory Applications, Office of Nuclear Regulatory Research, U. S. Nuclear Regulatory Commission, Washington, DC 20555

46. D. L. Morrison, Office of the Director, Office of Nuclear Regulatory Research, U. S. Nuclear Regulatory Commission, Washington, DC 20555

47. C. B. Nelson, Office of Radiation and Indoor Air, U.S. Environmental Protection Agency, 401 M. Street, S.W., Mail Code 6602J, Washington, DC 20460

48. C. J. Paperiello, Office of the Director, Office of Nuclear Materials Safety and Safeguards, U. S. Nuclear Regulatory Commission, Washington, DC 20555

49. H. T. Peterson, Jr., Air, Water and Radiation Division, Office of Environmental Guidance, U. S. Department of Energy, 1000 Independence Ave., SW, Washington, DC 20585

50. J. N. Piccone, Division of Industrial and Medical Nuclear Safety, Office of Nuclear Materials Safety and Safeguards, U. S. Nuclear Regulatory Commission, Washington, DC 20555

51. J. W. Poston, Department of Nuclear Engineering, College of Engineering, Texas A\&M University, College Station, TX 77843

52. A. C. B. Richardson, Deputy Director for Federal Guidance Criteria and Standards Division, United States Environmental Protection Agency, Washington, DC 20460

53. G. S. Roessler, Route 1, Box 139H, Elysian, MN 56028

54. G. Runkle, U. S. Department of Energy, Albuquerque Operations, Environmental Safety and Health Division, Albuquerque, NM 87115

55. K. W. Skrable, Dept. of Physics, U. of Lowell, 1 University Ave., Lowell, MA 01854 
56. A. Wallo, Air, Water and Radiation Division (EH-232), Office of Environmental Guidance, U. S. Department of Energy, 1000 Independence Ave., SW, Washington, DC 20585

57. M. F. Weber, Division of Waste Management, Office of Nuclear Materials Safety and Safeguards, U. S. Nuclear Regulatory Commission, Washington, DC 20555

58. W. Whicker, Professor, Department of Radiology and Health Sciences, Colorado State University, Fort Collins, CO 80523

59. S. S. Yaniv, Office of Nuclear Regulatory Research, U. S. Nuclear Regulatory Commission, Washington, DC 20555

60- Office of Scientific and Technical Information, P. O. Box 62, Oak Ridge, TN 37831 61. 